SAND 88-1331 $-\mathrm{UC}-814$

Unlimited Release

Printed April 1992

Yucca Mountain Site Characterization Project

\title{
G-Tunnel Welded Tuff Mining Experiment Instrumentation Evaluations
}

R. M. Zimmerman, R. A. Bellman, Jr., K. L. Mann, T. W. Thompson

Prepared by

Sandia National Laboratories

Albuquerque, New Mexico $8 \mathrm{r} 185$ and Livermore, California 94550

for the United States Department of Energy

under Contract DE-AC04-76DPOO789 
"Prepared by Yucca Mountain Site Characterization Project (YMSCP) participants as part of the Civilian Radioactive Waste Management Program (CRWM). The YMSCP is managed by the Yucca Mountain Project Office of the U.S. Department of Energy, DOE Field Office, Nevada (DOE/NV). YMSCP work is sponsored by the Office of Ceologic Repositories (OGR) of the DOE Office of Civilian Radioactive Waste Management (OCRWM)."

Issıed by Sandia National Laboratories, operated for the United States Department of Energy by Sandia Corporation.

NOTICE: This report was prepared as an account of work sponsored by an agency of the United States Government. Neither the United States Government nor any agency thereof, nor any of their employees, nor any of their contractors, subcontractors, or their employees, makes any warranty, express or implied, or assumes any legal liability or responsibility ior the accuracy, completeness, or usefulness of any information, apparatus, product, or process disclosed, or represents that its use would not infringe privately owned rights. Reference herein to any specific commercial product, process, or service by trade name, trademark, manufacturer, or otherwise, does not necessarily constitute or imply its endorsement, recommendation, or favoring by the United States Government, any agency thereof or any of their contractors or subcontractors. The views and opinions expressed herein do not necessarily state or reflect those of the United States Government, any agency there of or any of their contractors.

Printed in the United States of America. This report has been reproduced directly from the best available copy.

Available to DOE and DOE contractors from

Office of Scientific and Technical Information

PO Box 62

Oak Ridge, TN" 37831

Prices available from (615) 576-8401, FTS 626.8401

Available to the public from

National Technical Information Service

US Department of Commerce

5285 Port Royal Rd

Springfield, VA 22161

NTIS price codes

Printed copy: A06

Microfiche copy: $A 01$ 
SAND8 8 - 1331

Unlimfted Release

Printed April 1992

Distribution

Category UC- 814

G-TUNNEL WELDED TUFF MINING EXPERIMENT INSTRUMENTATION EVALUATIONS

\author{
by \\ Roger M. Zimmerman \\ Sandia National Laboratories \\ Albuquerque, NM \\ SAND--88-1331 \\ Robert A. Bellman, Jr., \\ Kevin L. Mann, and \\ DE92 013768 \\ T. William Thompson \\ Science Applications International Corporation \\ Las Vegas, NV
}

\begin{abstract}
Designers and analysts of radioactive waste repositories must be able to predict the mechanical behavior of the host rock. Sandia National Laboratories has conducted a mine-by experiment in welded tuff so that information could be obtained regarding the response of the rock to a drill and blast excavation process, where smooth-blasting techniques were used. This report describes the results of the evaluations of nine different instrument or measurement systems used in conjunction with these mining activities.
\end{abstract}


Data were gathered and analyses performed under WBS 1.2.4.2.1.2.

\section{ACKNOWLEDGMENTS}

The authors are indebted to many for their contributions to these welded tuff mining evaluations. In particular, we wish to acknowledge contributions from the following persons:

From Sandia National Laboratories

Robert L. Schuch For an excellent job of coordinating activities of personne 1 from SNL, SAIC, PBQ\&D, and REECo

Joe Bradshaw

For exceptional dedication in the preparation of equipment and collection of the permeability data as well as overall support for the needs of the program

Carl Deriney

For technical expertise leading to the setup of the data acquisition system and the conversion of Irad gages from manual to monitored measurements

Barbara Luke For extremely helpful comments and criticisms in the peer review

Larry Costin

For extremely helpful. comments and criticisms in the peer review

\section{From EG\&G}

Don Mason

For skill in developing the software for the data acquisition system and help in keeping it operating 


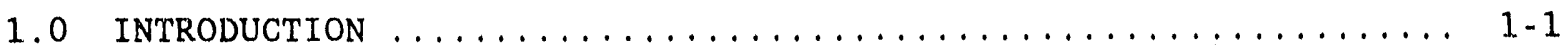

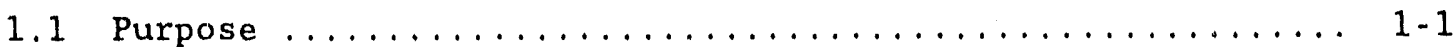

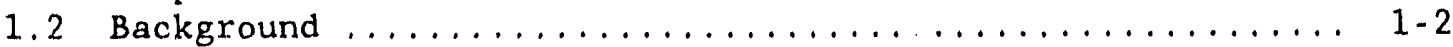

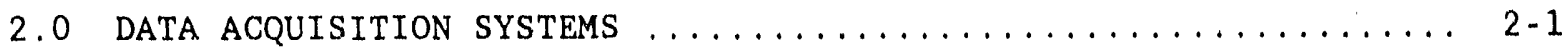

2.1 Computerized Data Acquisition $\ldots \ldots \ldots \ldots \ldots \ldots \ldots \ldots \ldots \ldots \ldots$

2.1.1 Components of the Data Acquisition System ....... 2-1

2.1 .2 Types of Instruments ................... 2-4

2.1 .3 Data Operations ..................... 2-4

2.2 Manually Recorded Data .................... 2-7

3.0 DAS-BASED INSTRUMENTATION DESCRIPTIONS AND EVALUATIONS $\ldots \ldots \ldots 3-1$

3.1 Multiple-Point Borehole Extensometers ............. $3-1$

3.1 .1 Measurement Components.................. 3.1

3.1 .2 Calibrations ........................ 3-3

3.1.3 Irad Multiple-Point Borehole Extensometer ....... 3-3

3.1.3.1 Measurement Equipment ............ $3-8$

3.1.3.2 Performance Observations ............ 3-8

3.1.3.3 Evaluation .................... $3-12$

3.1.4 Sinco/Terrametrics Multiple-Point

Borehole Extensometer ................... 3-13

3.1.4.1 Measurement Equipment ............. 3-13

3.1.4.2 Performance Observations ............ 3-13

3.1 .4 .3 Evaluation ...................... 3-19

3.1.5 Geokon Multiple-Point Borehole Extensometer ...... 3-20

3.1.5.1 Measurement Equipment ............. 3-20

3.1.5.2 Performance Observations ............. 3-20

3.1 .5 .3 Evaluation ................... 3-21

3.2 Borehole stressmeter ...................... 3-21

3.2.1 Measurement Equipment .................. 3-21

3.2.2 Sensor Calibrations/Con ersion Factors.......... 3-22

3.2.3 Performance Observations ................ 3-27

3.2 .4 Evaluation ........................ 3-29 
TABLE OF CONTENTS

(Continued)

Page

3.3 Rock Bolt Load Cell ....................... 3-30

3.3.1 Measurement Equipment .................. 3-30

3.3.2 Performance Observations ................. 3-32

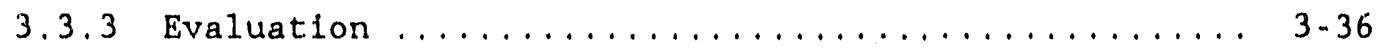

4.0 MANUAL MEASUREMENT DESCRIPTIONS AND EVALUATIONS $\ldots \ldots \ldots \ldots \ldots \ldots$. 1

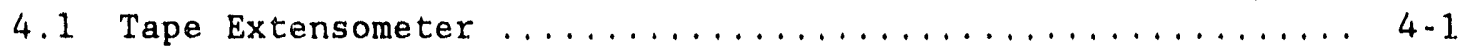

4.1 .1 Measurement Equipment $\ldots \ldots \ldots \ldots \ldots \ldots \ldots \ldots \ldots \ldots$ 4.1

4.1.2 Performance Observations ................. 4-3

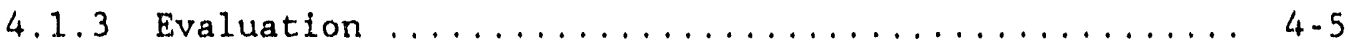

4.2 Borehole Injection $\ldots \ldots \ldots \ldots \ldots \ldots \ldots \ldots \ldots \ldots \ldots \ldots \ldots \ldots$

4.2.1 Measurement Principles .................. 4-5

4.2 .2 Measurement Equipment ................... 4-7

4.2.3 Performance observations ................ 4-10

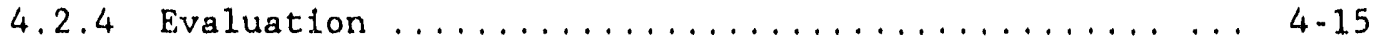

4.3 Borehole Deflectometer .................... 4-16

4.3.1 Measurement Principle ..................... 4-16

4.3 .2 Measurement Equipment ................... 4 . 18

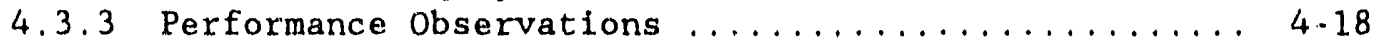

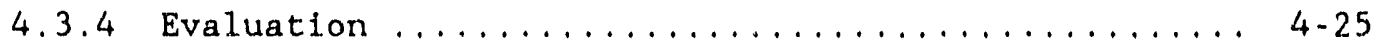

4.4 Hydraulic Pressure Cell ................... 4-26

4.4.1 Measurement Principle .................... 4-26

4.4.2 Measurement Equipment .................. 4-28

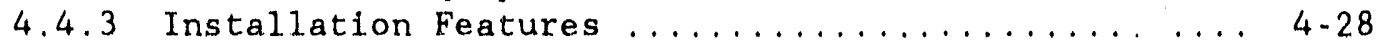

4.4.4 Performance observations .................. 4-28

4.4 .5 Evaluation ....................... 4-32

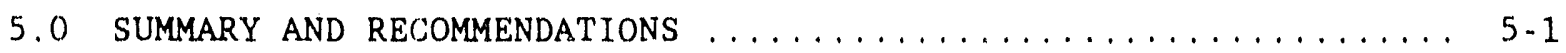

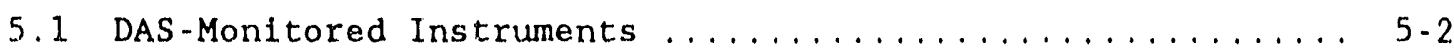

5.1.1 Multiple-Point Borehole Extensometers .......... 5-2

5.1.1.1 IRAD Multiple-Point Borehole

Extensometer.................. 5-2

5.1.1.2 Sinco/Terranetrics Multiple-Point.

Borehole Extensometer............... 5-3

5.1.1.3 Geokon Multiple-Point Borehole

Extensometer................... 5-3 
TABLE OF CONTENTS

(Concluded)

Page

5.1 .2 Borehole Stressmeters ................. 5.4

5.1 .3 Rock Bolt Load Cells .................... 5-4

5.2 Manually Read Measurements $\ldots \ldots \ldots \ldots \ldots \ldots \ldots \ldots \ldots \ldots$ 5-5

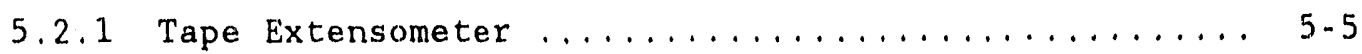

5.2 .2 Hydraulic Quotient .................... 5.5

5.2 .3 Borehole Deflectometer .................. 5.6

5.2 .4 Hydraulic Pressure Cells .................. 5-6

5.3 Recommendations $\ldots \ldots \ldots \ldots \ldots \ldots \ldots \ldots \ldots \ldots \ldots \ldots \ldots \ldots$

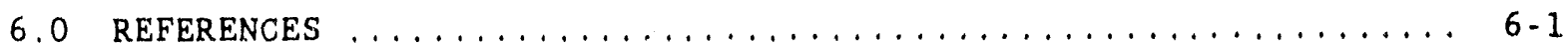

Appendix $A-R I B$ and SEPDB Database Information.............. A-I 


\section{LIST OF FIGURES}

Figure

Page

1-1 Plan View of Demonstration Drift Details Associated with Welded Tuff Mining Experiment ..................... 1-3

1-2 Elevation View Showing Location of Instrumentation and Measurement Holes Relative to Major Drifts with Typical. Geologic Features ............................ 1-4

2-1 Block Diagram Illustrating Data Acquisition System $\ldots \ldots \ldots \ldots 2-2$

3-1 Schematic Showing Typical MPBX Arrangement $\ldots \ldots \ldots \ldots \ldots \ldots \ldots$ 3-2

3-2 Raw and Averaged Output from the Irad MPBX .............. $3-9$

3-3 Vertical MPBX Displacement Histories at Stations $C$ and $E \ldots \ldots$....

3-4 Demonstration Drift Inclined MPBX Displacement Histories

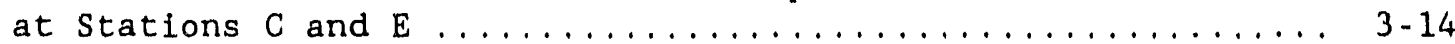

3-5 12-Drift Inclined MPBX Displacement Histories at

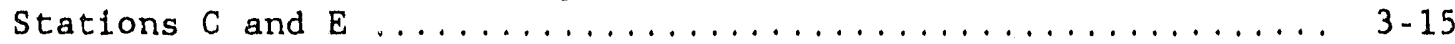

3-6 Horizontal MPBX Displacement Histories at Stations

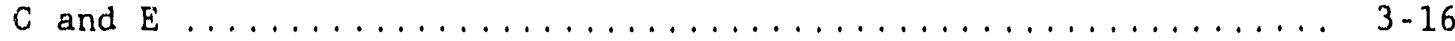

3.7 Schematics Showing BSM Placements .................. $3-23$

3-8 Schematics Showing Loading Methods for BSM Calibrations ..... 3-25

3-9 Force Change Histories for BSMs .................... 3-28

3-10 Elevation View Showing RBLC Layout $\ldots \ldots \ldots \ldots \ldots \ldots \ldots \ldots \ldots \ldots$

3-11 Configuration of Panel Before Grouting ................ 3-33

3-12 Force Histories for R.BLC Units 5-8 at Station E

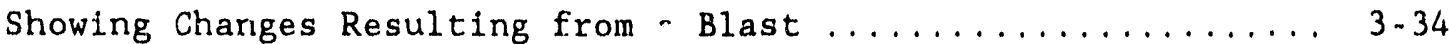

3-1.3 Force Histories for RBLC Units $13-16$ at Grouting Insert Showing Sequential Tightening Effects............ 3-34

3-14 Long-Term Force ,istories for RBLC Units $1-8 \ldots \ldots \ldots \ldots \ldots \ldots \ldots 35$

3-15 Long-Term Force Histories for RBLC Units $9-16 \ldots \ldots \ldots \ldots \ldots \ldots 37$

4-1 Tape Extensometer Measurement Arrangement .............. 4-2

4-2 Summary of Vertical Tape Extensometer Data .............. 4-4

4-3 Summary of Horizontal Tape Extensometer Data ............. 4-6

4-4 Schematics Showing Principle of Borehole Permeability Testing ............................... 4-8

4-5 Schematic of Permeability Testing Apparatus ............. 4-9

4-6 Pre- and Postmining HQ Profiles for Borehole B2 ......... 4-12

4-7 Pre- and Postmining HQ Profiles for Borehole B3 ........... 4-12

4-8 Pre- and Postmining HQ Profiles for Borehole D2 .......... 4-13

4-9 Pre- and Postmining HQ Profiles for Borehole D3 .......... 4-13

4-10 Pre- and Postmining HQ Profiles for Borehole F2 ............ 4-14

4-11 Pre- and Postmining HQ Profiles for Borehole $F 3 \ldots \ldots \ldots \ldots \ldots$ 4-14

4-12 Schematic Showing Mining-Related Deflectometer Measurement Concept .................................. 4-17

4-13 Schematic of Borehole Deflectometer in Casing ............ 4-19

4-14 Angle Change Profiles for Borehole B1 ............... 4-23

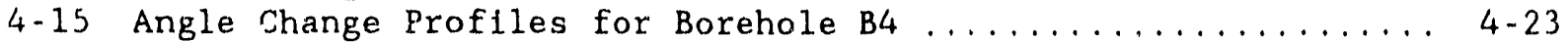

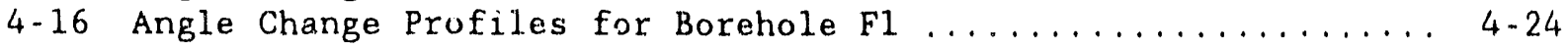

4-17 Angle Change Profiles for Borehole F4 ................ $4-24$ 
LIST OF FIGURES

(Concluded)

Figure

Page

4-18 Schematic Showing Major Components of Hydraulic Pressure

Ce11................................... 4-27

4-19 Schematics Showing Details of the Hydraulic Pressure Cel1.... 4-29

4-20 Histories for Hydraulic Pressure Cell Units 1, 2, 3,

and 4 in South Grout Insert...................... 4-30

4-21 Histories for Hydraulic Pressure Cell Units 5, 6, 7,

and 8 in North Grout Insert ..................... 4-31 


\section{LIST OF TABLES}

Table

Page

2-1 Descriptive Information for Computer-Based Measurements....... 2-5

2-2 Descriptive Information for Manually Obtained Data ........... 2-8

3-1 Descriptive Information for Instruments Connected to the DAS ....................................... $3-4$

3-2 Summary of Conversion Factor Measurements............... 3-24

4-1 Initial Convergence Station Measurements ............... 4-3

4-2 Summary of Computed Values for BD Error Analyses ........... 4-20

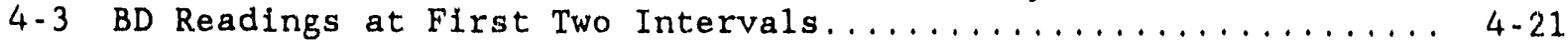




\subsection{INTRODUCTION}

\section{1 purpose}

Designers and analysts within the Yucca Mountain Profect (YMP) have conducted experiments in G-Tunnel on the Nevada Test Site for the purpose of characterizing tuffs as possible host rocks for a nuclear waste repository (DOE, 1980). Tuffs in nearby Yucca Mountain are being considered for the repository and experiments in the G-Tunnel Underground Facility (GTUF) allow characterizations without expensive excavation and facility development costs. A welded tuff mining (WTM) experiment was conducted in the GTUF to assess responses of tuffs to the excavation processes (Zimmerman et a1., 1991).

This report is the last in a series of four covering the G-Tunnel Welded Tuff Mining (WTM) Experiment. The first report (Zimmerman et al., 1991), covering experiment preparations, contains background, rationale, and provides the purpose of the experiment. It also gives details of the measurement systems and includes topics on measurement principles, measurement equipment, and installation details and procedures. The second report (Zimmerman et al., 1990) provides the data summary in engineering units. Also included in the report are calibration data and error analyses for two new developmental efforts. The third report (Zimmerman et al., 1988) provides evaluations of the WTM experiment with emphasis on the rockmass behavior. Major subjects discussed are (1) mining and ground support design, (2) drift convergence phenomena, and (3) relaxed zone behavior.

This fourth report provides descriptions and evaluations of the instruments that were used in the WTM. Instruments were used both in the continuously monitored data acquisition system (DAS) and in manual measurement activities. Major subjects discussed for the various types of instruments are measurement equipment and performance. Evaluations are provided for possible applications of these instruments in future testing. 
Instruments and measurement techniques included in these evaluations are three types of multiple-point borehole extensometers (MPBXs), borehole stressmeters (BSMs), rock-bolt load cells (RBLCs), a tape extensometer (TE), borehole-injection (BI) methods, borehole deflectometer (BD), and hydraulic pressure cells (HPCs). The instrumentation performance is evaluated in each of the chapters and then an overall summary and . instrumentation recommendations are provided in the last chapter.

Many of the details of the first three reports are not repeated here. Appropriate figures and data are repeated and pertinent details are liber. ally referenced to the preparations report (Report $A$ ), the data summary report (Report B), and the experiment evaluations report (Report $C$ ).

\subsection{Background}

The WTM experiment was conducted in the GTUF using two drifts (Report A). Figure 1-1 shows a plan view of the two drifts. The first drift constructed was the 12-Drift extension. The 12-Drift served as the observation drift, where boreholes were drilled into the rock mass into which the Demonstration Drift would be mined. These boreholes were used for measurements before, during, and after the excavation of the Demonstration Drift.

Figure 1-1 shows the measurement stations that were used as locators for both the Demonstration Drift and the 12-Dलift. Pertinent dimensions are shown in the figure. Measurements were normally identified with stations, which were identified with mining rounds. Two stations, $C$ and E, were located at predetermined distances in the Demonstration Drift because of the presence of station-dependent instrumentation originating from the 12 -Drift.

Also shown in Figure $1-1$ are the major geologic features, including a fault and fractures. These were visually mapped from the inside of the drift (Report A). The unnamed normal fault (strike $\mathrm{N} 50^{\circ} \mathrm{W}$, dip $75^{\circ} \mathrm{E}$, 


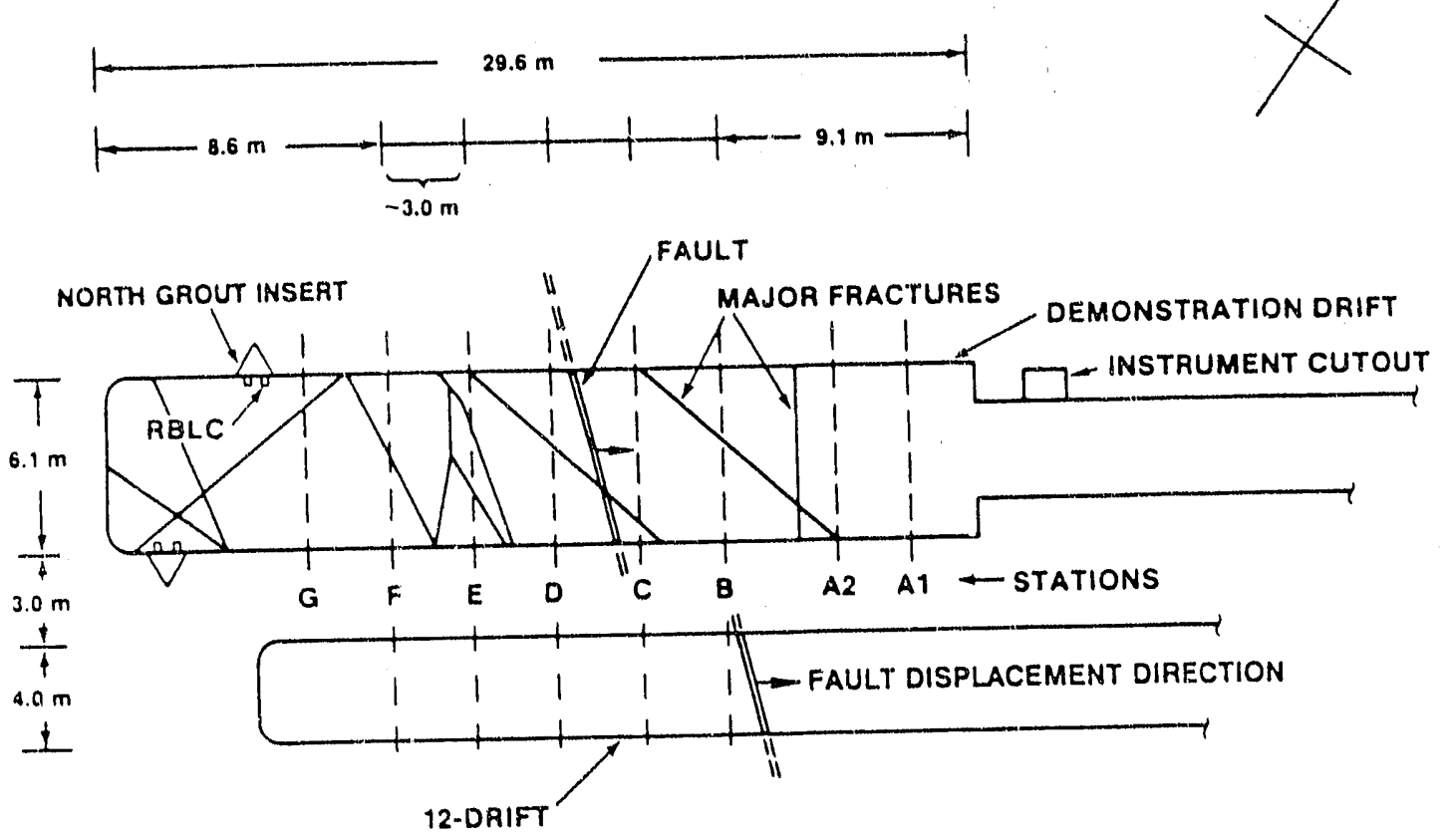
Figure 1-1. Plan View of Demonstration Drift Detalls Associated with
Welded Tuff Mining Experiment

displacement $-2.5 \mathrm{~m}$ ) was also observed in the 12 -Drift, where it has a 3.6-m displacement as determined by a G-Tunnel geologist. Major fractures also are shown in Figure 1-1. The fractures dip subvertically.

Figure 1-2 shows a representative elevation view of the two drifts with pertinent dimensions and major instrumentation positions (Report A). Multiple-point borehole extensometers (MPBXs), with origins in the Demonstration Drift, were located in Positions 1-6, and MPBXs were located with origins in the 12-Drift and identified as Position 7. MPBXs were located only at Stations $C$ and E. MPBXs are identified by station and position number; thus, a vertical MPBX oriented up at Station $C$ would be identified as MPBX C3.

The four long boreholes originating from the 12-Drift, identified by \#1-4 in Figure 1-2, were located at Stations B, D, and F. These boreholes were used for special types of pre- and postmining measurements. Measurements in the steepest borehole at Station $B$ would be identified as Borehole B1. 


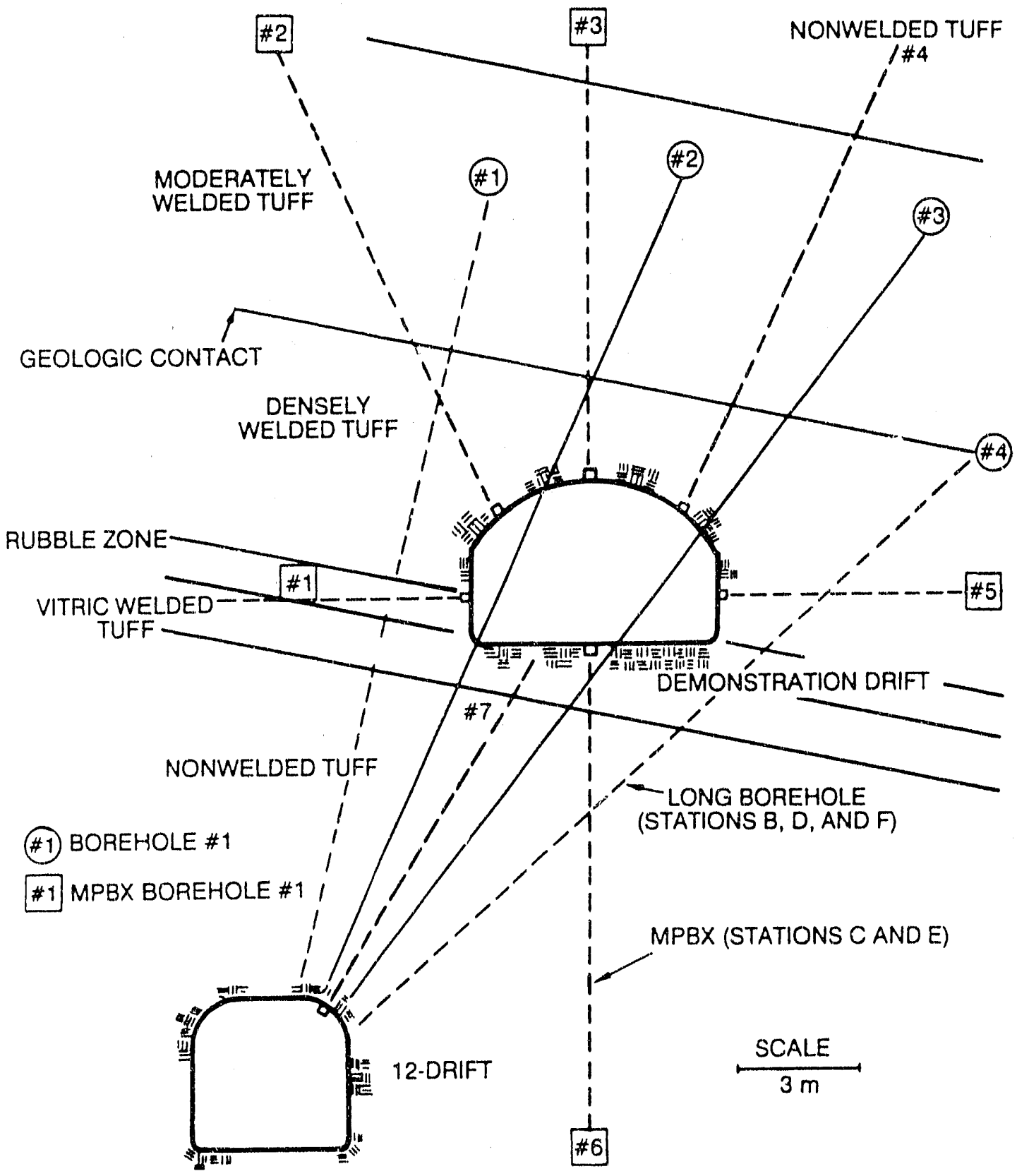

Figure 1-2. Elevation View Showing Location of Instrumentation and Measurement Holes Relative to Major Drifts with Typical Geologic Features

The Demonstration Drift was located in multilayered tuff as shown in Figure 1-2 of Report A. Because of the fault, portions of the floor of the drift were located at the bottom of the densely welded tuff, in the rubble zone, and in the vitric welded tuff. In general, measurement stations Al through $C$ were essentially in densely welded tuff. The floor for Stations $D$ through $G$ was in vitric and rubblized tuff. 


\subsection{DATA ACQUISITION SYSTEMS}

\subsection{Computerized Data Acquisition}

The computer-based Data Acquisition System (DAS) was located in the Instrumentation Alcove, which was a part of the GTUF.

\subsubsection{Components of the Data Acquisition System}

The flow diagram describing the computer-based DAS is shown in Figure 2-1. Essential components of the system were

(1) sensor excitation and signals,

(2) a digital voltmeter/scanner,

(3) a desk top computer,

(4) hard disk storage,

(5) floppy disk storage,

(6) sensor power supplies, and

(7) an uninterruptible power supply.

These components are briefly discussed in the following paragraphs.

The sensors used employed one of the following measurement technologies: electrical resistance strain gages, direct current-1inear variable differential transformers (DC-LVDT), potentiometers, or sonic wave travel time measurement. These sensors required different types of excitation and signal conditioning, and details are discussed in the respective instrumentation sections. 


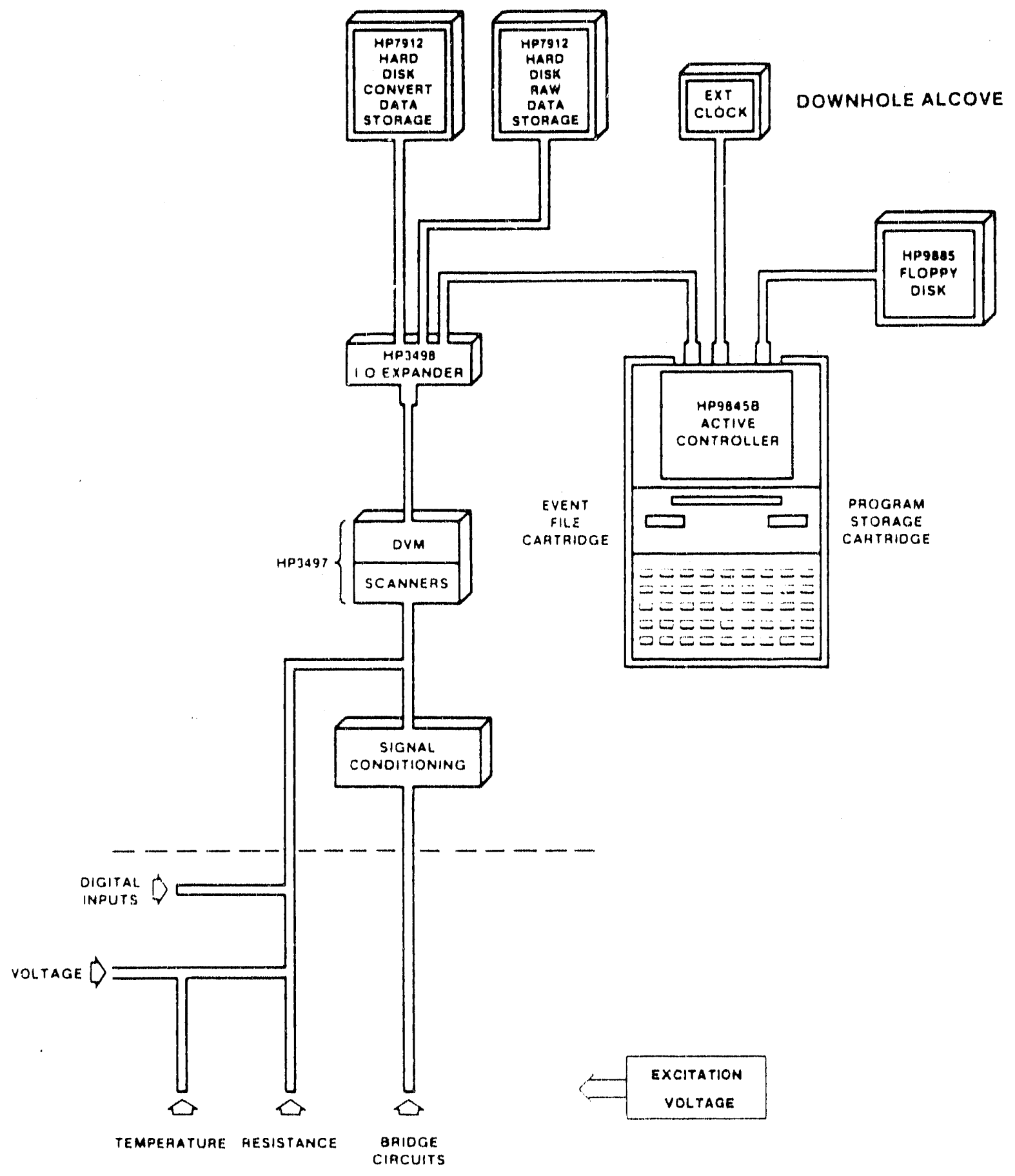

Figure 2-1. Block Diagram Illustrating Data Acquisition System 
The Hewlett Packard (HP) 3497 digital voltmeter (DVM)/scanner was the DAS voltage monitoring unit used to record sensor outputs. The sensors were under continuous excltation from power supplies located in the instrumentation alcove. Eight different power supplies provided excitation voltages directly to the function boxes near the sensors. Different power supplies were used for different types of instruments and for multiple units of similar instruments. Excitation voltages at junction boxes were continuously monitored in the DAS.

An HP 9845 B desk top computer served as the central processing unit. Acquisition of data usually occurred at regular intervals that were specified by the investigators and controlled through the computer.

Output signals from the sensors were stored on two HP 7912 hard disks. Raw output voltages were stored on one disk, and converted data were stored on the other. Converted data were obtained using software stored in the computer. The computer could provide for conversions from voltages to the corresponding engineering units and would allow a limited amount of data manipulation. Storage on separate units provided backup capability in case or malfunction of one of the units.

Data were converted from raw voltages using calibration factors and initial values stored in the calibration file. The calibration file was stored on an HP 9885 floppy disk.

The DAS system was powered by an Elcard, Model 252-1, 2.5-kW uninterruptible power supply (UPS). The UPS was connected to the tunnel instrumentation power line; thus, it was under continuous charge. The UPS was used to provide (1) continuous and constant voltage power to the DAS and power supplies, (2) stability to variations of instrumentation line power, and (3) uninterrupted power if there was a loss of line power. The UPS could operate at a rate of $2.5 \mathrm{~kW}$ for up to $5 \mathrm{hr}$ without recharging. 


\subsubsection{Types of Instruments}

Table 2-1 1ists the number and different types of instruments that were monitored on the DAS. Different sensors are identified with acronyms for later convenience. Also included in the table are descriptions of the sensor principles and excitation voltage requirements.

\subsubsection{Data Operations}

The normal mode of operation was for the data to be recorded and stored on the HP 7912 hard disks at G-Tunnel, and then all available files and programs were transferred to a tape cassette, which was hand-cairied to Albuquerque for additional processing for use in reports. Data were collected in a series of scans, each of which consisted of a recording of the DVM/scanner outputs for each channel and then conversion of the voltages to reduced data. Complete processing for a scan took less than 3 min. Each scan (thus each channel) was identified by time, scan number, file number, and calibration file reference number. The latter was used because it was necessary to make changes in the calibration file as new instruments were brought on 1 ine, and because a complete record of all calibration activities needed to be maintained. The time records were expressed in terms of $\mathrm{J}$-Days, which were numerical accountings of days in dectimal form starting with the first day of each calendar year. In many tables and plots, J-Days are followed by the year to facilitate interpretations.

Scanning frequencies were set by the DAS operator in G-Tunnel through the use of special function keys on the computer. Special function keys were available to

(1) change the scan rate and set times for scans;

(2) cause the computer to force a scan immediately;

(3) disable data printing on the internal printer so that there were no hard copy records of scans; 


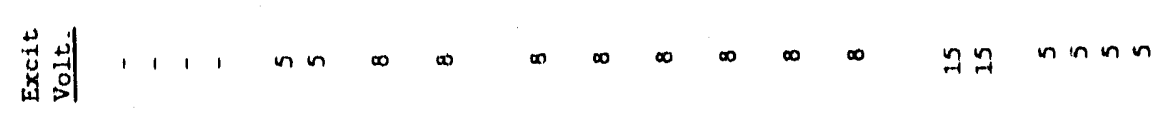

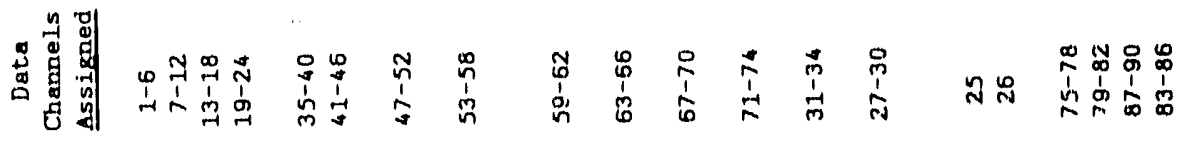

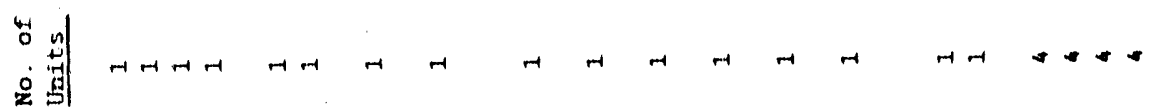

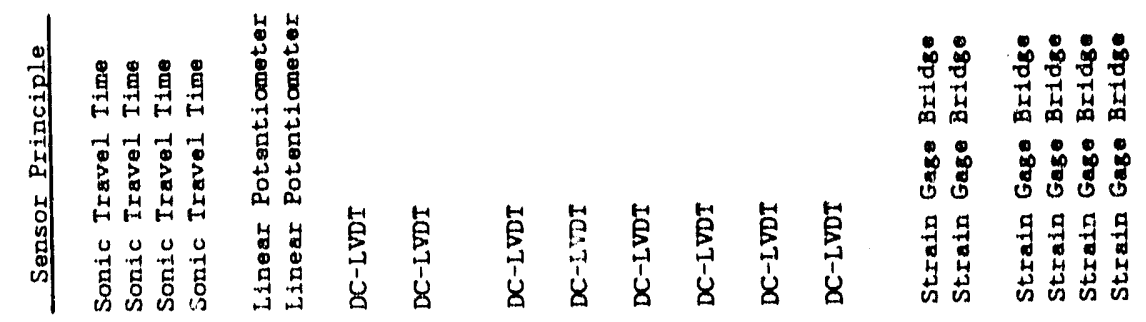

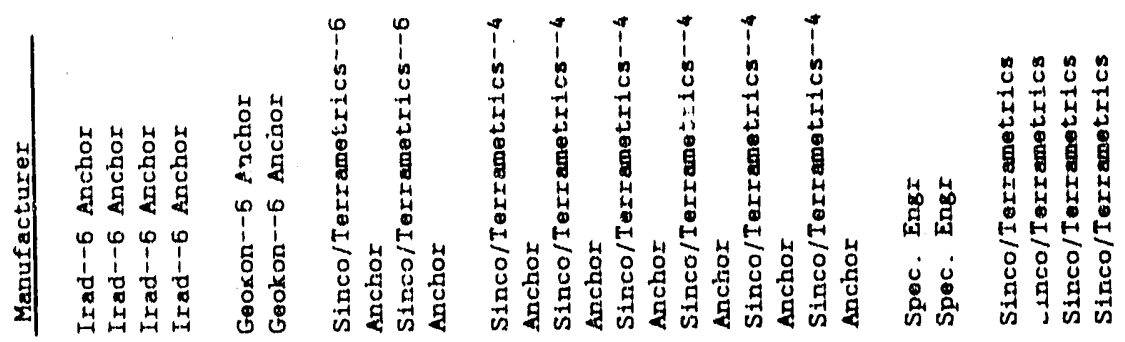

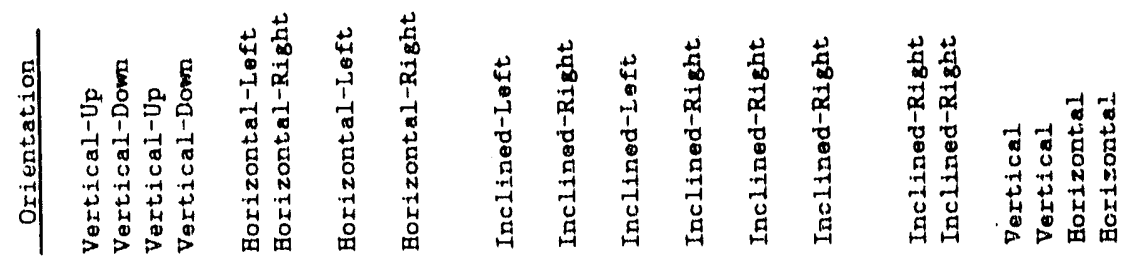

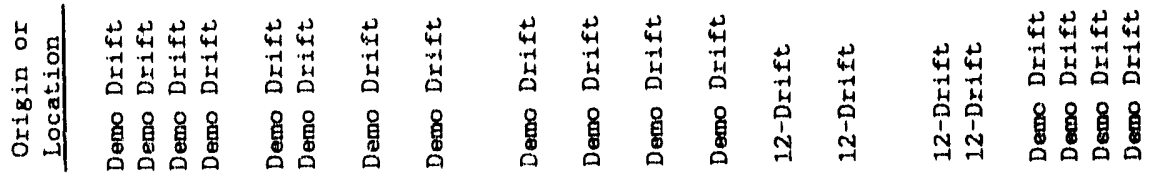

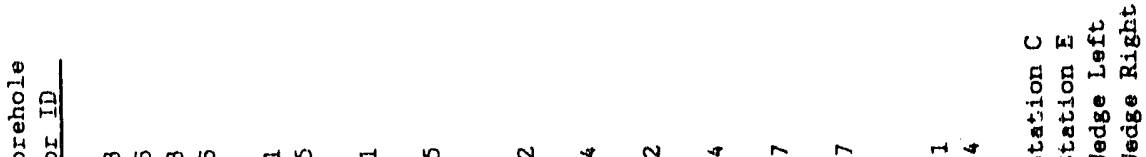

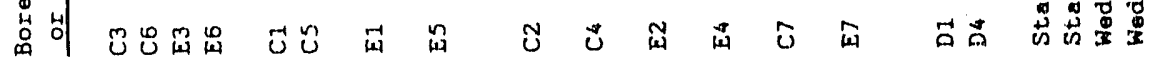
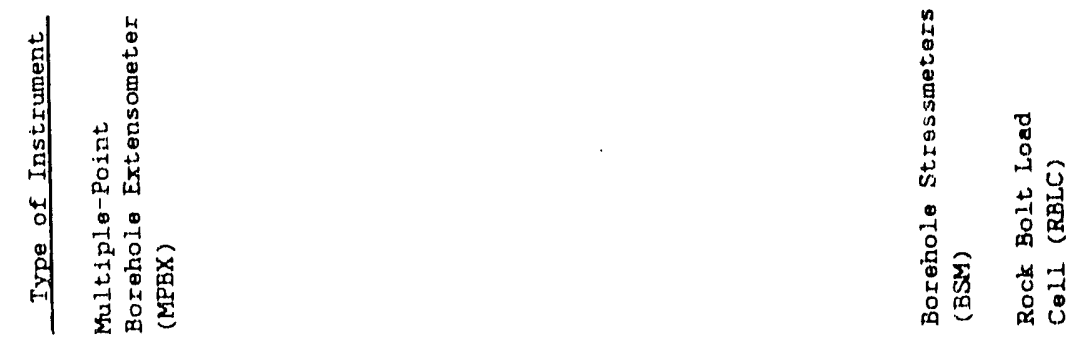
(4) re-enable data printing on the internal printer so that scan records could be printed either as a full record or a single line indicating time, scan number, file number, and calibration file used;

(5) plot data versus time on the internal printer;

(6) view and edit the calibration file (a new flle number was automatically recorded if a calibration file was changed); and

(7) stop the program.

There were a number of dates that were important in the DAS operations for defining periods if data monitoring for various sensors:

November 22, 1985 ( $\mathrm{J}$-Day 326), initialization of BSM \#1;

December 9, 1985 (J-Day 343), Initialization of MPBXs in 12-Drift;

December 18, 1985 (J-Day 352), initialization of BSM \#2;

March 5, 1986 (J-Day 64), initialization of MPBXs at Station C;

Apri1 19, 1986 (J-Day 111), Initialization of MPBXs at Station E;

Apri1 29, 1986 (J-Day 121), Initialization of RBLCs In Demonstration Drift;

September 10, 1986 (J-Day 253), initialization of RRLCs in grout inserts; and

December 9, 1986 (J-Day 3/,3), termination of data recording. 


\subsection{Manual1y Recorded Data}

Data were recorded on special forms for each of the manual recording systems. The forms were designed for each type of instrument by personnel from Science Applications International Corporation (SAIC). Table 2-2 summarizes the different types of measurements recorded manually. 


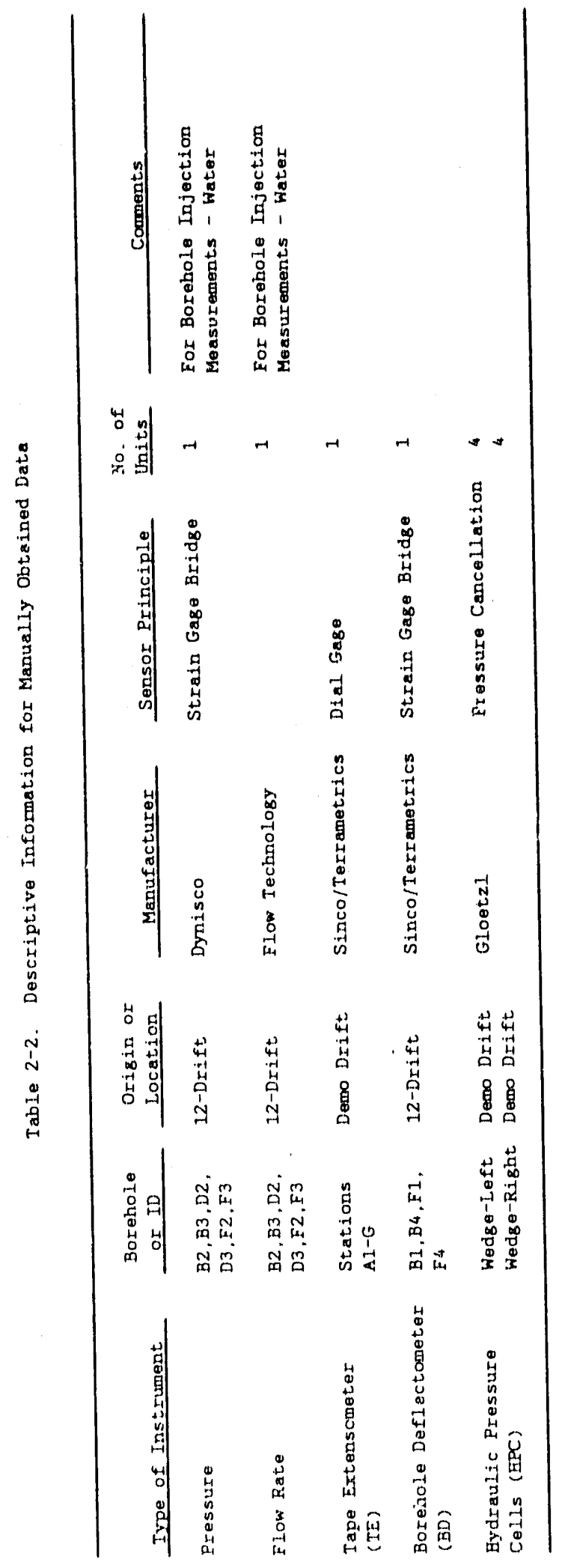




\subsection{DAS-BASED INSTRUMENTATION DESCRIPTIONS AND EVALUATIONS}

This chapter introduces, describes, and evaluates the instruments and transducers that were connected to the DAS.

\subsection{Multiple-Point Borehole Extensometers}

Multiple-point borehole extensometers are widely used in geomechanics to measure relative displacements between points in a rock mass. MPBX.s can have sensors that are manually read or monitored in a DAS. The MPBX applications can be enhanced during excavation-related evaluations if the relative displacements can be continuously monitored so that time-dependent relaxation of the rock can be followed. The sensors used for continuous monitoring operate on electronic principles, which can be sensitive to shock waves created during blasting. A goal in these WTM evaluations was to evaluate three different types of electronic sensors in a typical blasting environment.

\subsubsection{Measurement Components}

The measurement components associated with an MPBX are discussed in reference to Figure 3-1. An MPBX consists primarily of the head, the collar pipe, the rods, and the anchors.

The head contains the sensors. Usually the head has a removable cover to protect the sensors. The main function of the head is to serve as a flxture to transfer movements of rod ends to appropriate sensors. The sensors selected were (1) a sonic probe, manufactured by Irad, (2) a DCLVDT, manufactured by sinco/Terrametrics, and (3) a linear potentiometer, manufactured by Geokon.

The collar pipe primarily serves to fix the head to the end of the borehole. In addition, some collar pipes are designed by the manufacturers for other purposes. For instance, the collar pipe for the Irad MPBX contained some of the sensing instrumentation and had to be longer than the others. 


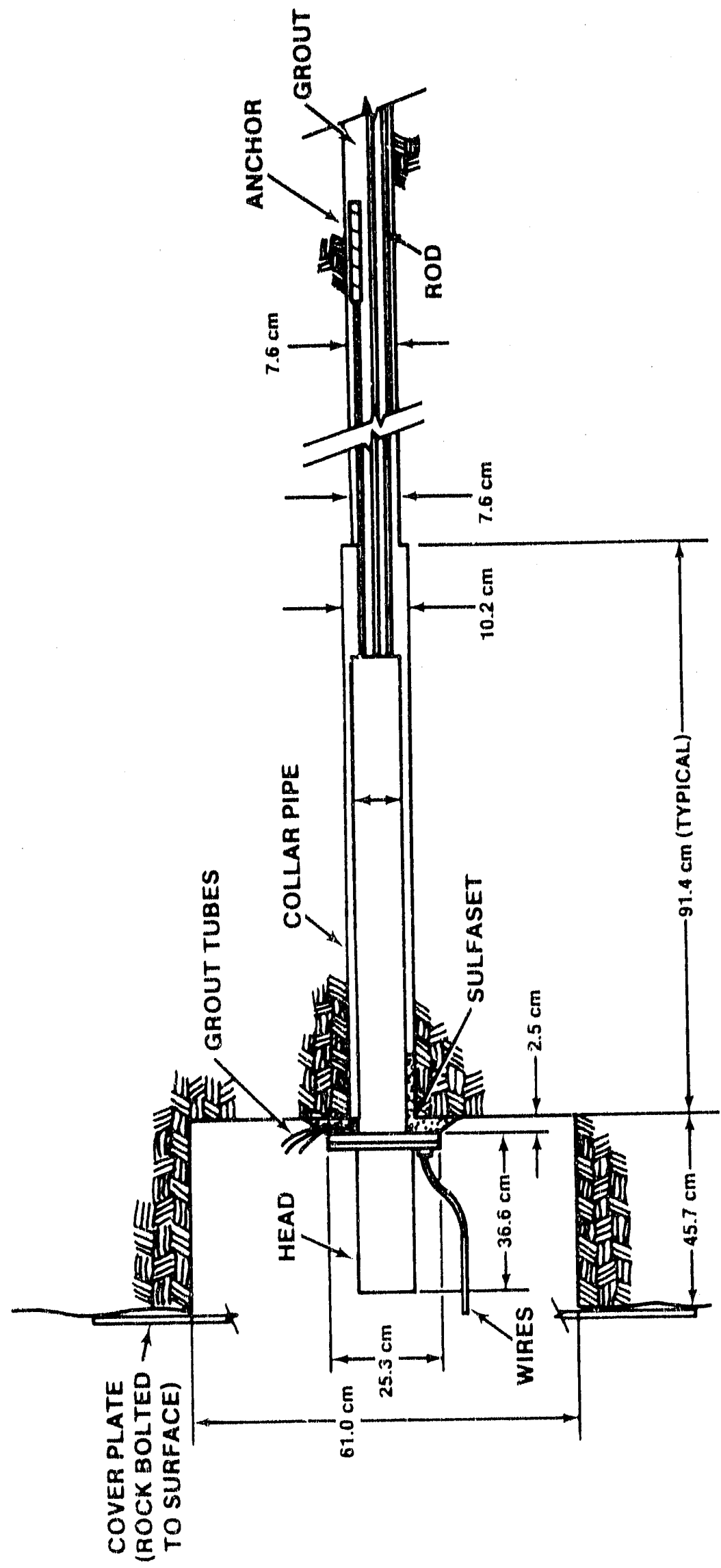

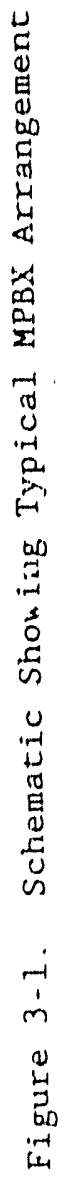


The rods serve as connecting mechanisms between the anchors and sensors. The ldeal rod should remain friction fres in the borehole and should remain relatively insensitive to thermal gradients. Friction reduction is achleved by enclosing the rod in a plastic or metallic conduit so that grout or loose rock fragments do not interfere with the rod movements. Spectal metals are used in MPBXs when there are temperature gradients. All WTM work was planned for amblent temperatures, which remain quite stable in the tuff in G-Tunnel, and only stainless steel rods were used,

There are a number of anchor types commerclally avallable, such as mechanical, hydraulic, and grouted. Grouted anchors had been selected for use in the fractured welded tuff in other work and performed well (Zimmerman et a1., 1986). Grouted anchors have advantages for long-term monftoring and were assumed to be more stable in a blast environment; thus, they were selected for use in these evaluations. A feature in the use of grouted anchors was the insertion of structural discontinuities in the grout columns so that individual anchors would be isolated from each other. The overall grouting procedures are discussed in Reports $A^{a}$ and $C^{b}$. Table 3-1 summarizes the locations of the anchors for the MPBX units as well as descriptive information for other instrumentation connected to the DAS (Report A). Data.channel identification also is provided in the table.

\subsubsection{Calibrations}

MPBXs were calibrated in the SAIC laboratory by comparing physical measurements performed with the sensors to the voltage or digital outputs from the sensor using procedures recommended by the manufacturers. Results are avallable in Report $B .^{\circ}$

\subsubsection{Irad Multiple-Point Borehole Extensometer}

Irad MPBXs were selected for use in the WTM because of two design features: (1) high resistance to electrical interference and (2) the

a. Zimmerman et al., 1991

b. Zimmerman et al., 1988

c. Zimmerman et al., 1990 
Table 3-1. Descriptive Information for Instruments Connected to the DAS

Multiple-Point Borehole Extensometer

\begin{tabular}{|c|c|c|c|c|c|}
\hline $\begin{array}{c}\text { Date } \\
\text { Inttlallzed }\end{array}$ & $\begin{array}{c}\text { Hole } \\
\text { ID } \\
\end{array}$ & $\begin{array}{l}\text { Instrument } \\
\text { Description }\end{array}$ & $\begin{array}{c}\text { Anchor } \\
\text { No. }\end{array}$ & $\begin{array}{c}\text { Anchor } \\
\text { Depth from } \\
\text { Cul1 ar } \\
\text { (m) }\end{array}$ & $\begin{array}{c}\text { DAS } \\
\text { Channe1 } \\
\text { No. } \\
\end{array}$ \\
\hline $11 / 22 / 85$ & $\begin{array}{l}\text { In- } \\
\text { clined } \\
\text { E7 }\end{array}$ & $\begin{array}{l}\text { Sinco/Terra- } \\
\text { metrics } \\
\text { MPBX \#9 }\end{array}$ & $\begin{array}{l}1 \\
2 \\
3 \\
4\end{array}$ & $\begin{array}{r}10.0 \\
9.1 \\
8.1 \\
7.2\end{array}$ & $\begin{array}{l}27 \\
28 \\
29 \\
30\end{array}$ \\
\hline $11 / 22 / 85$ & $\begin{array}{l}\text { In- } \\
\text { clined } \\
\text { C7 }\end{array}$ & $\begin{array}{l}\text { Sinco/Terra. } \\
\text { metrics } \\
\text { MPBX \#10 }\end{array}$ & $\begin{array}{l}1 \\
2 \\
3 \\
4\end{array}$ & $\begin{array}{r}10.0 \\
9.1 \\
8.1 \\
7.2\end{array}$ & $\begin{array}{l}31 \\
32 \\
33 \\
34\end{array}$ \\
\hline $03 / 04 / 86$ & $\begin{array}{l}\text { Uphole } \\
\text { C3 }\end{array}$ & $\begin{array}{l}\text { Irad Sonic } \\
\text { Probe } \\
\text { MPBX \#1 }\end{array}$ & $\begin{array}{l}1 \\
2 \\
3 \\
4 \\
5 \\
6\end{array}$ & $\begin{array}{r}14.3 \\
1.2 \\
1.6 \\
2.9 \\
4.0 \\
4.9\end{array}$ & $\begin{array}{l}1 \\
2 \\
3 \\
4 \\
5 \\
6\end{array}$ \\
\hline $03 / 04 / 86$ & $\begin{array}{l}\text { Down- } \\
\text { hole } \\
\text { C6 }\end{array}$ & $\begin{array}{l}\text { Irad Sonic } \\
\text { Probe } \\
\text { MPBX \#2 }\end{array}$ & $\begin{array}{l}1 \\
2 \\
3 \\
4 \\
5 \\
6\end{array}$ & $\begin{array}{r}14.3 \\
1.2 \\
2.0 \\
3.0 \\
4.0 \\
5.0\end{array}$ & $\begin{array}{r}7 \\
8 \\
9 \\
10 \\
11 \\
12\end{array}$ \\
\hline $03 / 04 / 86$ & $\begin{array}{l}\text { Hori- } \\
\text { zontal } \\
\text { Left } \\
\text { Rib } \\
\text { C1 }\end{array}$ & $\begin{array}{l}\text { Geokon } \\
\text { MPBX \#5 }\end{array}$ & $\begin{array}{l}1 \\
2 \\
3 \\
4 \\
5 \\
6\end{array}$ & $\begin{array}{r}14.0 \\
1.2 \\
2.0 \\
3.0 \\
4.0 \\
5.0\end{array}$ & $\begin{array}{l}35 \\
36 \\
37 \\
38 \\
39 \\
40\end{array}$ \\
\hline $03 / 04 / 86$ & $\begin{array}{l}\text { Hori- } \\
\text { zontal } \\
\text { Right } \\
\text { Rib } \\
\text { C5 }\end{array}$ & $\begin{array}{l}\text { Geokon } \\
\text { MPBX \#6 }\end{array}$ & $\begin{array}{l}1 \\
2 \\
3 \\
4 \\
5 \\
6\end{array}$ & $\begin{array}{r}14.0 \\
1.2 \\
2.0 \\
3.0 \\
4.0 \\
5.0\end{array}$ & $\begin{array}{l}41 \\
42 \\
43 \\
44 \\
45 \\
46\end{array}$ \\
\hline
\end{tabular}


Table 3-1. Descriptive Information for Instruments Connected to the DAS (Continued)

Multiple-Point Borehole Extensometer

\begin{tabular}{|c|c|c|c|c|c|}
\hline $\begin{array}{c}\text { Date } \\
\text { Initialized }\end{array}$ & $\begin{array}{c}\text { Hole } \\
\text { ID } \\
\end{array}$ & $\begin{array}{l}\text { Instrument } \\
\text { Description } \\
\end{array}$ & $\begin{array}{l}\text { Anchor } \\
\text { No. }\end{array}$ & $\begin{array}{c}\text { Anchor } \\
\text { Depth from } \\
\text { Collar } \\
(\mathrm{m}) \\
\end{array}$ & $\begin{array}{c}\text { DAS } \\
\text { Channe } 1 \\
\text { No. } \\
\end{array}$ \\
\hline $03 / 04 / 86$ & $\begin{array}{l}\text { In- } \\
\text { clined } \\
\text { Left } \\
\text { Rib } \\
\text { C2 }\end{array}$ & $\begin{array}{l}\text { Sinco/Terra- } \\
\text { metrics } \\
\text { MPBX \#11 }\end{array}$ & $\begin{array}{l}1 \\
2 \\
3 \\
4\end{array}$ & $\begin{array}{r}14.0 \\
1.2 \\
2.0 \\
3.0\end{array}$ & $\begin{array}{l}59 \\
60 \\
61 \\
62\end{array}$ \\
\hline $03 / 0 / 4 / 86$ & $\begin{array}{l}\text { In- } \\
\text { clined } \\
\text { Right } \\
\text { Rib } \\
\text { C4 }\end{array}$ & $\begin{array}{l}\text { Sinco/Terra- } \\
\text { metrics } \\
\text { MPBX \#12 }\end{array}$ & $\begin{array}{l}1 \\
2 \\
3 \\
4\end{array}$ & $\begin{array}{r}14.0 \\
1.2 \\
2.0 \\
3.0\end{array}$ & $\begin{array}{l}63 \\
64 \\
65 \\
66\end{array}$ \\
\hline $04 / 29 / 86$ & $\begin{array}{l}\text { Uphole } \\
\text { E3 }\end{array}$ & $\begin{array}{l}\text { Irad } \\
\text { Probe } \\
\text { MPBX \#3 }\end{array}$ & $\begin{array}{l}1 \\
2 \\
3 \\
4 \\
5 \\
6\end{array}$ & $\begin{array}{r}14.0 \\
1.2 \\
2.0 \\
3.0 \\
4.0 \\
5.0\end{array}$ & $\begin{array}{l}13 \\
14 \\
15 \\
16 \\
17 \\
18\end{array}$ \\
\hline $04 / 29 / 86$ & $\begin{array}{l}\text { Down- } \\
\text { hole } \\
\text { E6 }\end{array}$ & $\begin{array}{l}\text { Irad } \\
\text { Probe } \\
\text { MPBX \#4 }\end{array}$ & $\begin{array}{l}1 \\
2 \\
3 \\
4 \\
5 \\
6\end{array}$ & $\begin{array}{r}14.0 \\
1.2 \\
2.0 \\
3.0 \\
4.0 \\
5.0\end{array}$ & $\begin{array}{l}19 \\
20 \\
21 \\
22 \\
23 \\
24\end{array}$ \\
\hline $04 / 29 / 86$ & $\begin{array}{l}\text { In- } \\
\text { clined } \\
\text { Left } \\
\text { Rib } \\
\text { E2 }\end{array}$ & $\begin{array}{l}\text { Sinco/Terra- } \\
\text { metrics } \\
\text { MPBX \#13 }\end{array}$ & $\begin{array}{l}1 \\
2 \\
3 \\
4\end{array}$ & $\begin{array}{r}14.0 \\
1.2 \\
2.0 \\
3.0\end{array}$ & $\begin{array}{l}67 \\
68 \\
69 \\
70\end{array}$ \\
\hline $04 / 29 / 86$ & $\begin{array}{l}\text { In- } \\
\text { clined } \\
\text { Rib } \\
\text { E4 }\end{array}$ & $\begin{array}{l}\text { Sinco/Terra- } \\
\text { metrics } \\
\text { MPBX \#14 }\end{array}$ & $\begin{array}{l}1 \\
2 \\
3 \\
4\end{array}$ & $\begin{array}{r}14.0 \\
1.2 \\
2.0 \\
3.0\end{array}$ & $\begin{array}{l}71 \\
72 \\
73 \\
74\end{array}$ \\
\hline
\end{tabular}


Table 3-1. Descriptive Information for Instruments Connected to the DAS (continued)

Multiple-Point Borehole Extensometer

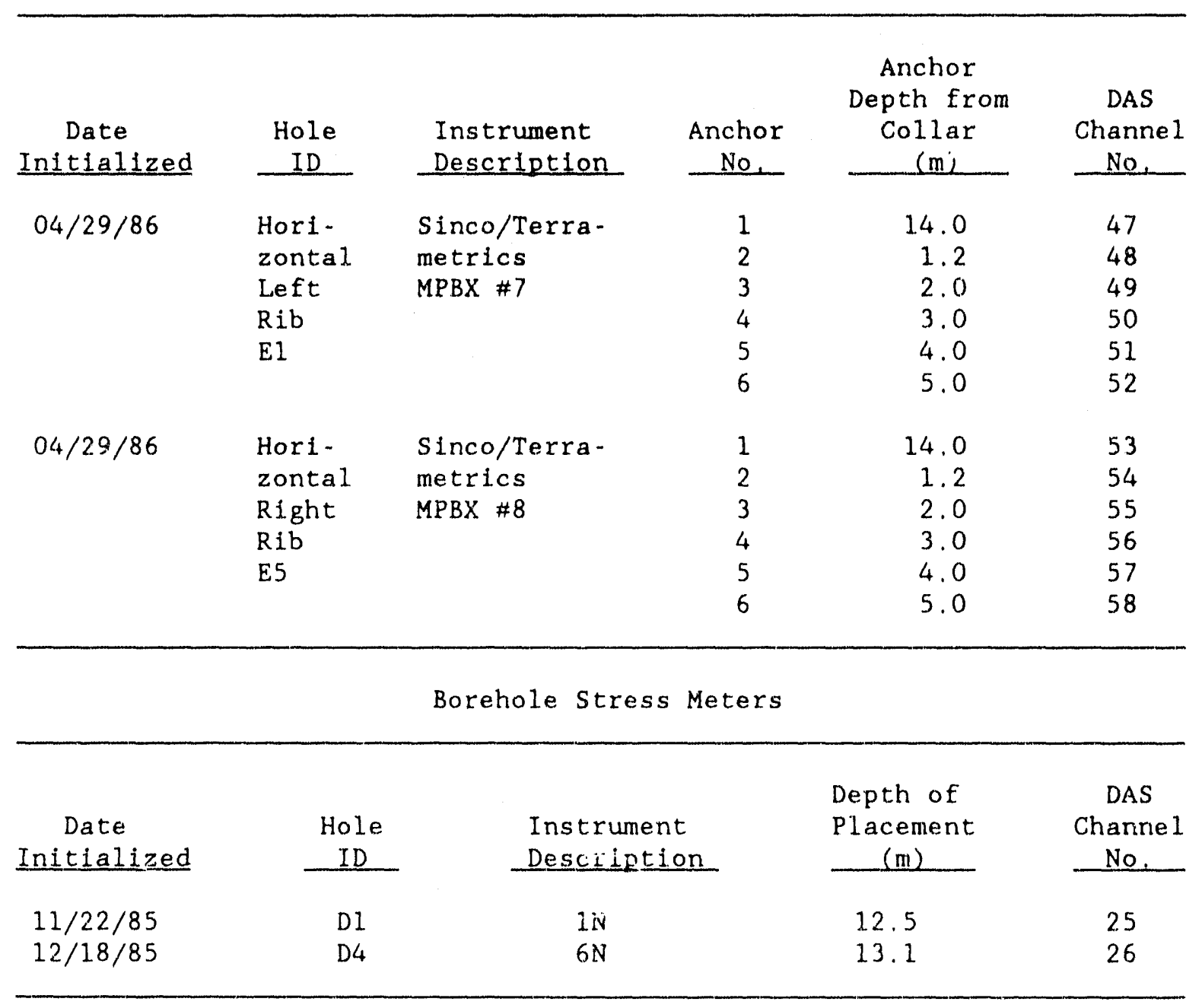


Table 3-1. Descriptive Information for Instruments Connected to the DAS (Concluded)

Rock Bolt Load Cell

\begin{tabular}{lllc}
\hline $\begin{array}{c}\text { Date } \\
\text { Initialized }\end{array}$ & $\begin{array}{c}\text { Unit } \\
\text { No. }\end{array}$ & Location & $\begin{array}{c}\text { DAS } \\
\text { Channe1 } \\
\text { No }\end{array}$ \\
\hline $04 / 29 / 86$ & 1 & Station C & 75 \\
$04 / 29 / 86$ & 2 & Station C & 76 \\
$04 / 29 / 86$ & 3 & Station C & 77 \\
$04 / 29 / 86$ & 4 & Station C & 78 \\
$04 / 30 / 86$ & 5 & Station E & 79 \\
$04 / 30 / 86$ & 6 & Station E & 80 \\
$04 / 30 / 86$ & 7 & Station E & 81 \\
$04 / 30 / 86$ & 8 & Station E & 83 \\
$09 / 10 / 86$ & 9 & North Insert & 84 \\
$09 / 10 / 86$ & 10 & North Insert & 85 \\
$09 / 10 / 86$ & 11 & North Insert & 87 \\
$09 / 10 / 86$ & 12 & South Insert & 88 \\
$09 / 10 / 86$ & 13 & South Insert & 89 \\
$09 / 10 / 86$ & 14 & South Insert & 90 \\
$09 / 10 / 86$ & 15 & South Insert & \\
$09 / 10 / 86$ & 16 & & \\
\hline
\end{tabular}

ability to interchange electronic and manual (dial gage micrometer) sensing units. The sonic principle used with the Irad units employs time measurements in the MPBX head and converts them to distrnce measurements with a digital readout meter (DRM). This means that the cable between the MPRX and the data logger is insensitive to undesirable voltage surges that can be induced by underground mining activities. The unit is designed for data transmission distances up to $183 \mathrm{~m}$. The second design feature addressed the possibility that sensors with electronic components could not be used in instruments placed in close proximity to the blast face because of relatively high ground accelerations and/or vibrations. It was anticipated that the manual measurements might have to be used until the blast face had advanced some distance from the instrument. 


\subsubsection{Measurement Equipment}

Irad, Model 4500--6 anchor, MPBXs were used in the WTM evaluations (Table 3-1). Sonic probes were used for all measurements. The collar pipe on this model is normally $1.8 \mathrm{~m}$ long. The collar pipe was shortened and the location of the anchor nearest to the head was changed by Irad to $1.2 \mathrm{~m}$ to facilitate desired measurements near the surface.

The sonic probe measures the time interval required for a stress wave to travel between two or more points in a tube containing a magnetostrictive material. Individual anchors are attached to magnets in the probe through the rods, and movements of the magnets cause changes in the time intervals. The time interval measurement is converted to a displacement through an Irad Sonic Probe MB-7 DRM.

The Irad MPBX was designed to operate as a manually operated unit, and anchor displacements normally would be read directly on the DRM. Sandia National Laboratories (SNL) purchased the DRM with an external BNC connection plug. SNL designed and fabricated a driver circuit and relay switching circuit to interface with the DAS and DRM. These items were configured to operate within the DAS so that the normal DAS scan operation would address prescribed channels in the DRM and transfer the digital distance outputs to the DAS.

\subsubsection{Performance Observations}

Figure 3-2 shows a sample data output for the Irad MPBXs that were used in the DAS. Mining activities occurred through J-Day 151, which means that sensor variations after that could be a result of instrument or DAS drift, or a result of time-dependent deformation of the rock mass. Figure 3-2a shows outputs of raw data that were received in normal scan operations. The data were considered excessively noisy. The noise is primarily attributed to the hardware that was used to connect the DRM to the DAS. A postprocessing averaging technique was used to display the data. Figure 3-2b shows the display of the data in Figure 3-2a after a nine-point averaging technique was applied (Report $B$ ). Figure 3-2b shows 


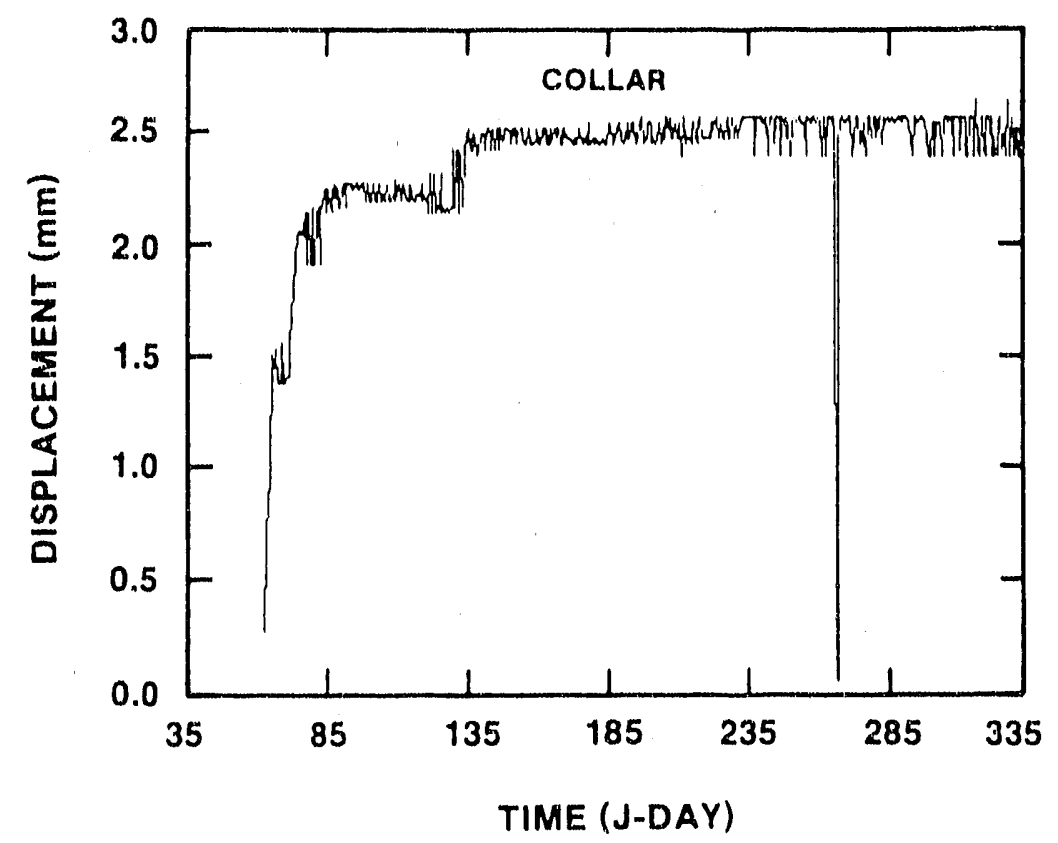

(a) Unfiltered Output-MPBX C3

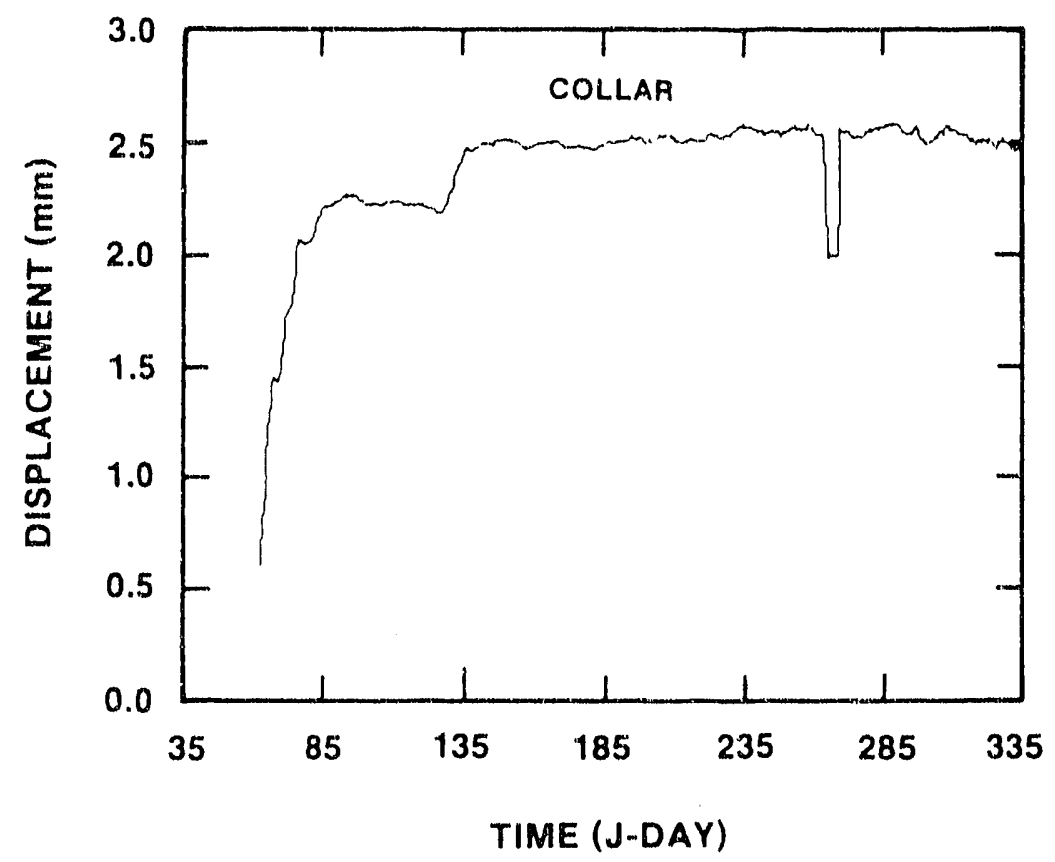

(b) Averaged Output-MPBX C3

Figure 3-2. Raw and Averaged Output from the Irad MPBX 
that the data trends were maintained with a slight lag time in sudden transitions in the data. The effects of the averaging on the perfod where there was loss of near J-Day 260 data are evident.

Figure 3-3 shows outputs for the four Irad units. The averaging technique was used. The four parts of the figure show the displacements of the MPBX heads relative to the bottom anchors. The plots in Figure 3-3 display most, but not all, of the data recorded. Data can only be plotted at a rate of 25 points/cm in the original figures. This means that some data are skipped by the computer in long time perlod plots. Short-term plots were used in preliminary evaluations to ensure that skipped data points in the computer sampling did not delete important transients that might be pertinent to the overall evaluations.

There were five measurement problens associated with the use of the Irad units. These problems and their probable causes are summarized as follows:

(1) Data for the first anchors in Units C3 and E3 were nearly the same as the collars (Figure 3-3a and $b$ ). The manufacturer installed the first anchor $15 \mathrm{~cm}$ from the end of the collar pipe. This was part of the special modification to the MPBX to allow measurements to be taken nearer to the drift surface. It appears that the anchors nearest the collar were not adequately separated for the grouting process used because expected differential measurements were not evident.

(2) The bottom anchor signal for Unit C6 was not recelved properly by the DRM, resulting in loss of data for that channel. The DRM indicated the bottom anchor rod had been positioned improperly, but visual checks indicated that it was properly placed. Measurements with a different DRM at the MPBX indicated a proper reading. The problem appears to be in the circuitry between the MPBX and the DAS. Data from the bottom anchor of Unit C6 are not shown in Figure 3-3c. Bottom relative displacements were referenced to the anchor located at: $5.0 \mathrm{~m}$. 


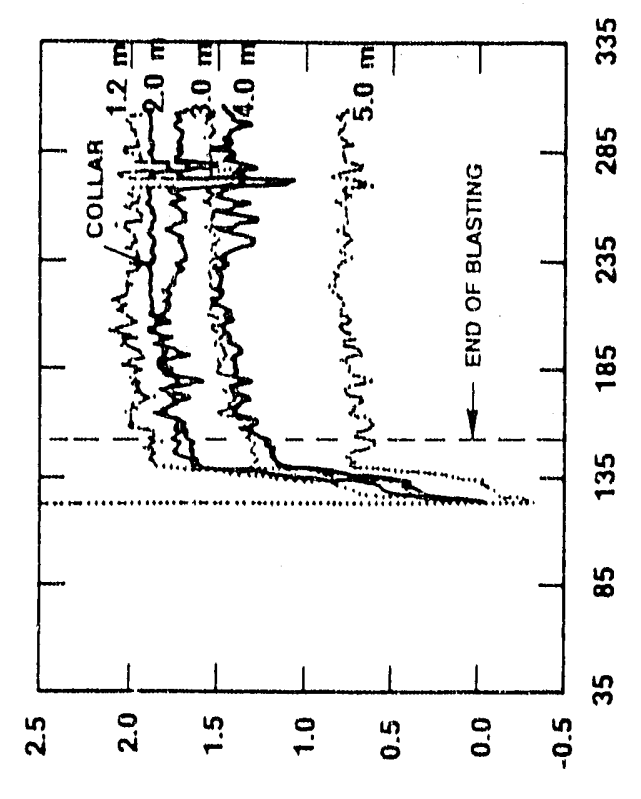

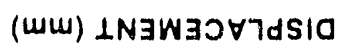

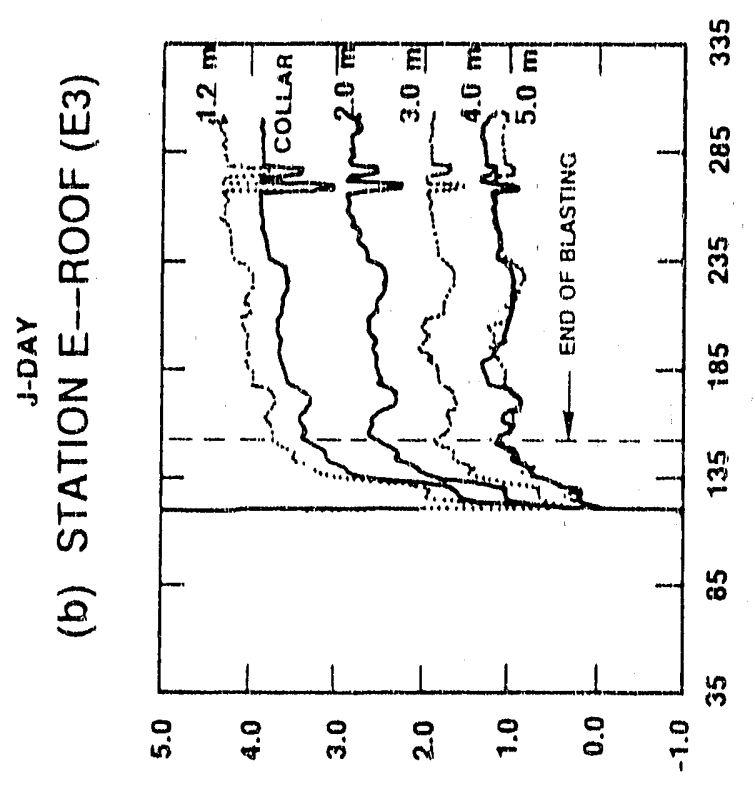

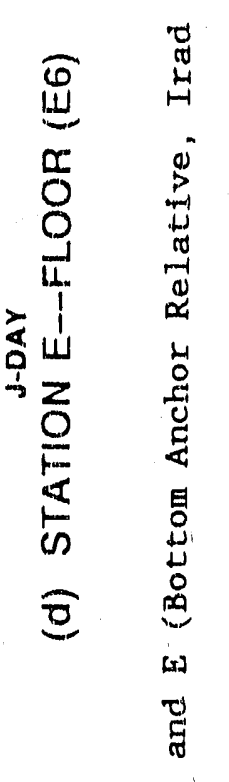

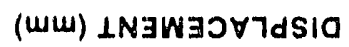
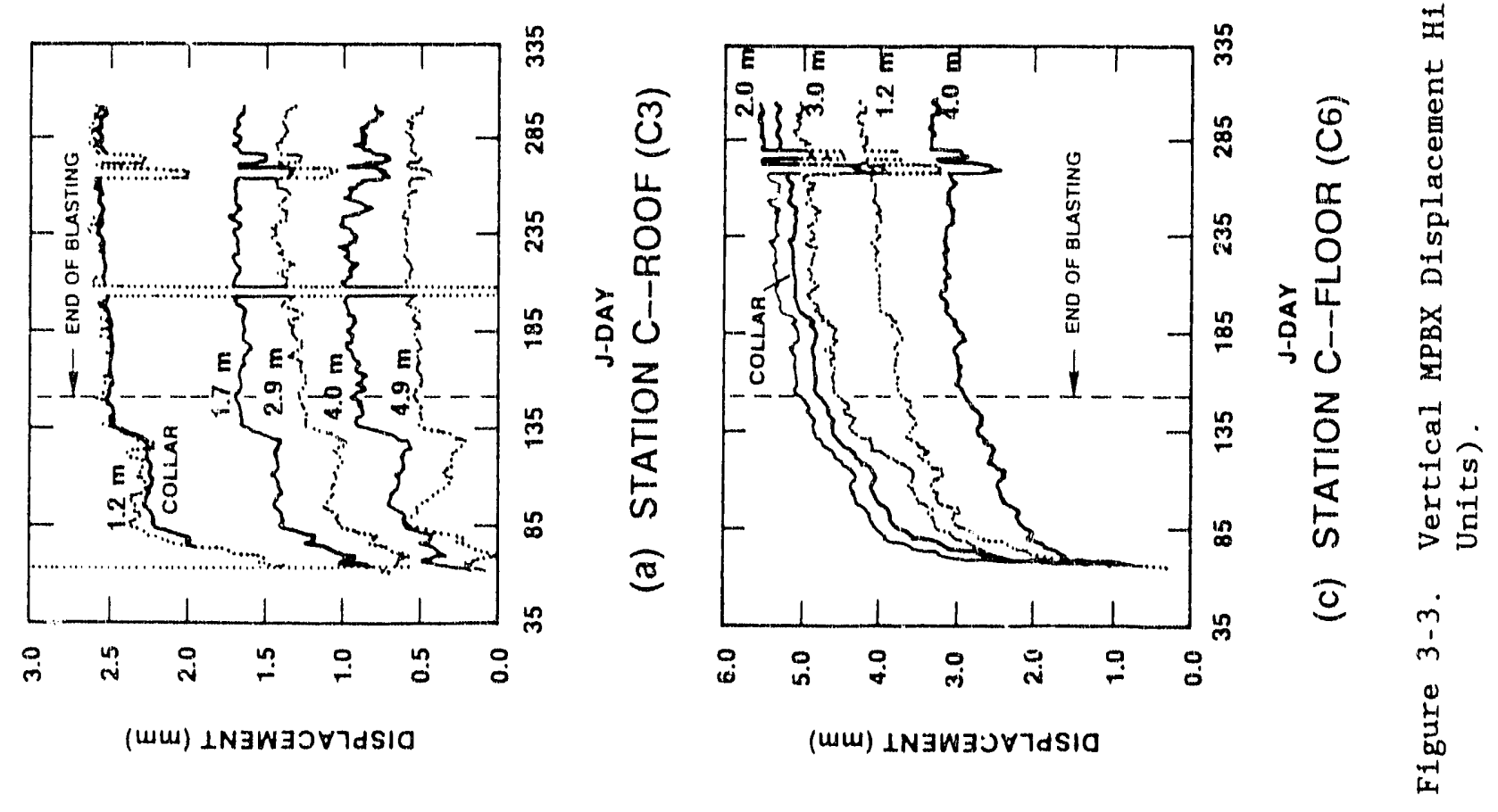
(3) There was signal loss in Unit C3 around J-Day 205 (Figure 3-3a). A check of the DAS records showed that the computer was not addressing the calibration file properly for the deepe:it anchor for that unit during the J-Day 205 time period. Because of the bottom anchor referencing system used (Report $B$ ), the readings for the other gages were shown as zero for that period. The reason for the data loss is considered to be operator error. No attempt was made to construct the lost data from the raw data file because of the absence of significant gradients.

(4) There was loss of power to the DAS because of failure of the autostart diesel on J-Days 276-77 and J-Day 295 (1986). Tunne1 power falled, and fallure of the autostart diesel to come on Ine caused the batteries to run down. No raw or converted data were recorded during this period.

(5) There was loss of converted data during the period J-Days 268-269 (1986) as a result of operator error in working with the DAS. During this period, raw data were recorded and stored, but improper commands to the callbration files in the floppy disks caused loss of converted data. Again, no reconstruction attempts were deemed necessary.

\subsubsection{Evaluation}

Four 6-anchor Irad MPBXs (sonic probe sensors) were installed in vertical holes: two up and two down. Because of a DAS-related instrument malfunction, data from one anchor were not recorded. Significant data were not recorded from two units with collars longer than the others because inadequate clearance was provided between the anchor and the collar pipe. The collar pipe used in this testing was modified by the manufacturer to make it shorter, yet it was the longest collar pipe of the three different types of MPBXs. The longer collar pipe is a disadvantage in the use of the Irad unit because it is normally desirable to take measurements near the surface of a drift. As a final note, only the Irad MPBXs required special signal processing to monitor them on the DAS, and more design effort is needed to reduce noise and improve signal accountability. An advantage of 
the sonic principle was not entirely realized when the normally manually read MPBX was modified to be monitored on the DAS. Overall evaluations of these and other MPBXs are contained in Chapter 5.

\subsubsection{Sinco/Terrametrics Multiple-Polnt Borehole Extensometer}

Sinco/Terrametrics, Mode1 6.CSLT (6 anchor) and Model 4-CSLT (4 anchor), MPBXs were used in the measurements (Table 3-1). These MPBXs used DC-LVDT sensors and were selected because of (1) previous satisfactory experiences in the $G$-Tunnel heated block measurements (Zimmerman et $a 1$., 1986), (2) the use of tensioned anchor rods, and (3) the built-in capability for in situ calibrations. The authors wished to evaluate the friction reduction aspects of these instruments in the high-acceleration environment associated with the blasting.

\subsubsection{Measurement Equipment}

The sensors were manufactured by Trans Tek, Mode1 043-11. The sensors operate on the principle of a DC-LVDT. A DC-LVDT contains two mafor components: (1) the body, which contains the electronics, and (2) the sliding core, which translates with the anchor movement. When the body is excited with a stable reference voltage $\left(E_{d}\right)$, the interaction of the body and the core results in a voltage output indicating the relative position of the two components.

\subsubsection{Performance Observations}

Displacement outputs from the Model 4-CSLTs are shown in Figuxe 3-4 for the Demonstration Drift (bottom anchor relative), and Figure 3-5 show: similar histories for the two units placed in the 12-Drift. The histories in Figure 3-5 were referenced to the collar because of the location of the head in the 12-Drift. Displacement outputs from the horizontally oriented Model 6-CSLTs are shown in Figure 3-6 (bottom anchor relative). The flgure also shows measurement histories for the Geokon units, which are discussed in Section 3.1.5. Data losses for J-Days 268-69 and J-Days 276-277 (1986) were discussed in section 3.1.3.2. 


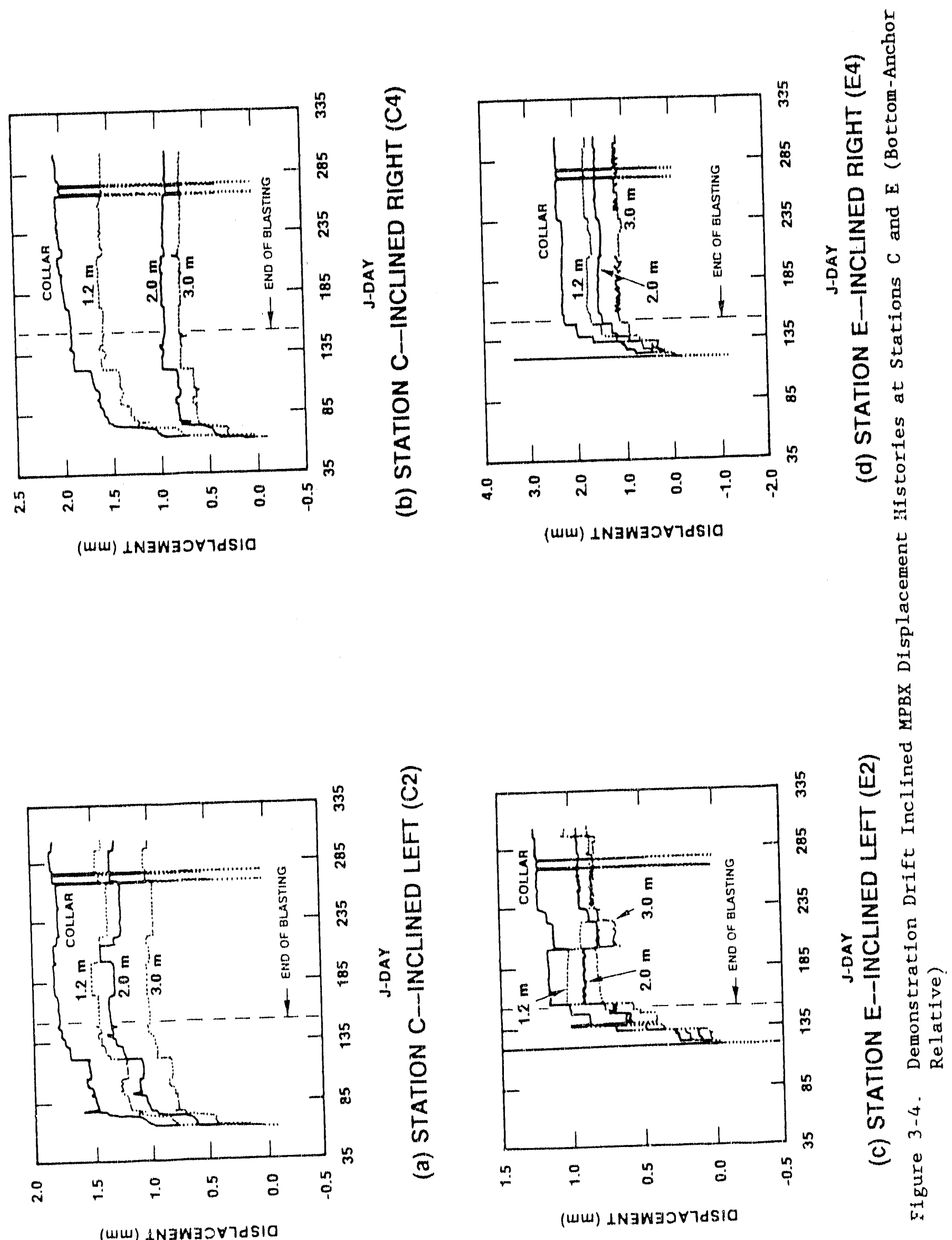




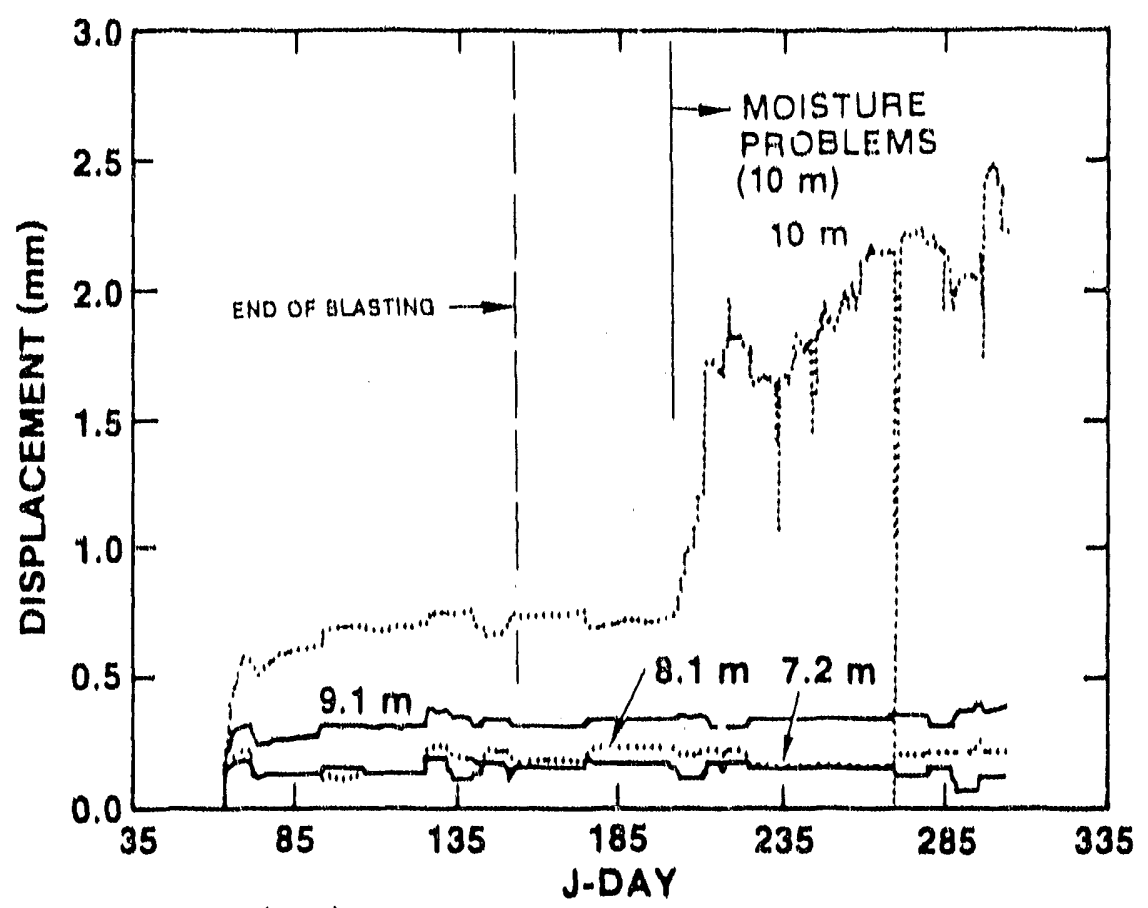

(a) STATION C (C7)

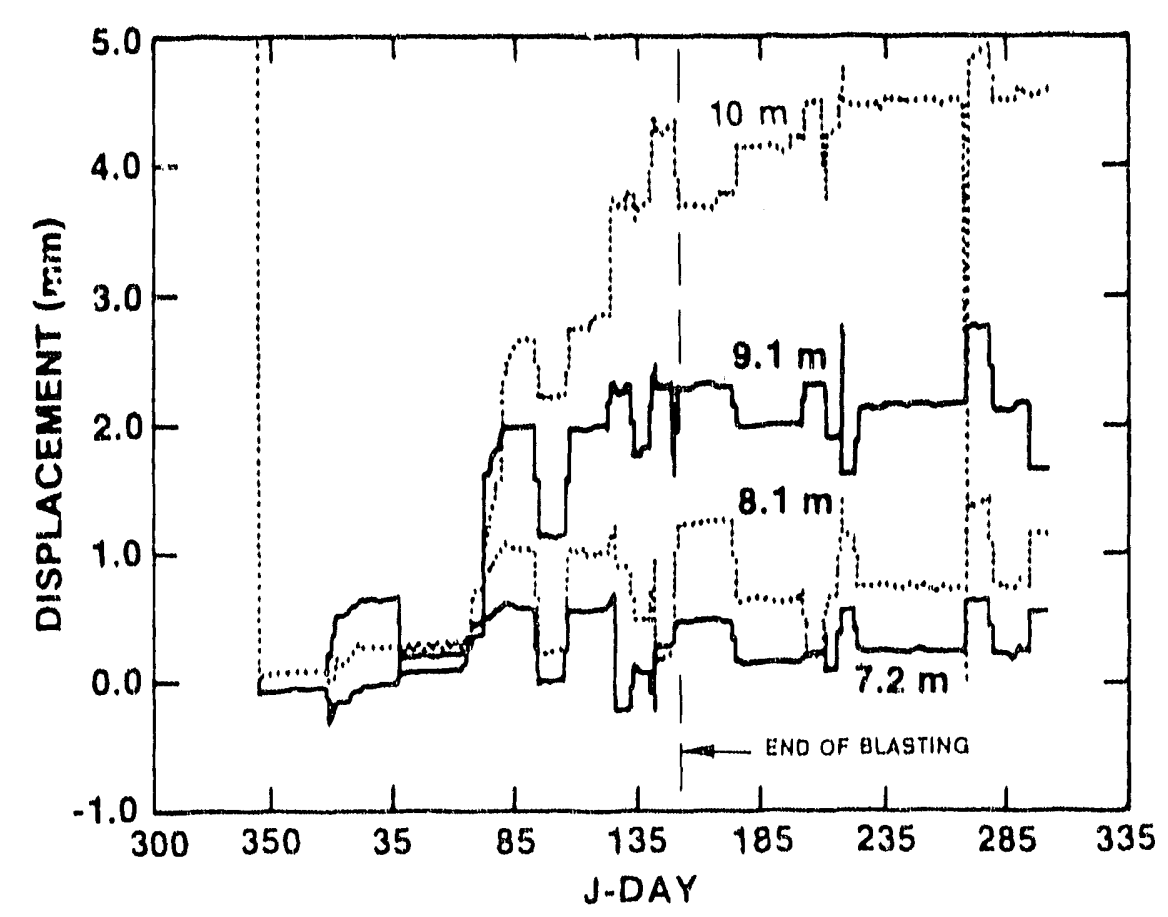

(b) STATIONE (E7)

Figure 3-5, 12-Drift Inclined MPBX Displacement Historles at Stations C and $E$ (Collar Relative) 


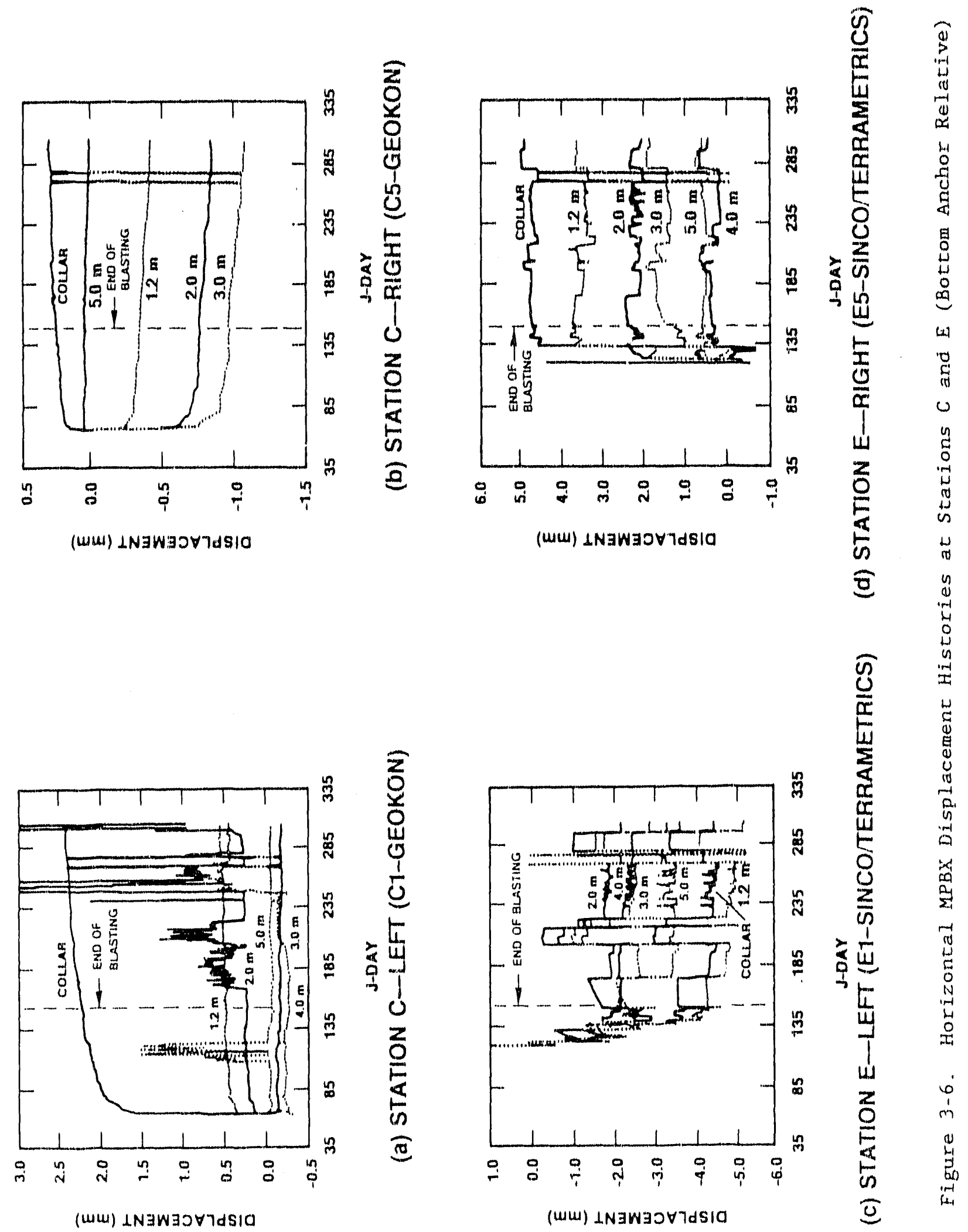


One of the features of the stnco/Terrametrics undts 1 s the use of tenstoned anchors. The application of tension on the measurement rods helps to reduce the amount of slack fin the rods. Anchor movements toward the collar can Indicate unchor slippar. Figures 3-4 through 3-6 do not appear to display any relative displacements toward the heads that inght be Induced by any signtficant anchor silp. It is reasoned that the grouting process took care of potential slip associated with seating of the anchor in the grout column.

There were two measurement problems assoclated with the use of the Sinco/Terrametrics untes. Thase problems and their probable causes are summarized as follows:

(1) The sensor for the anchor at $10 \mathrm{~m}$ on Unit C7 showed dramatic displacement changes after J-Day 206 (1986). Inspection of the MPBX head on J-Day 231 (1986) showed apparent molsture problems. Water, which possibly came fiom nearby borehole infection (BI) testing (Report A), was found in the cover.

(2) The DC-LVD'Ts on most units were particularly sensitive to changes In voltage excltation. Nonuniform performance of the power supply system during the period J-Days $174-2.3$ (1986) resulted in variations in DC-LVDT outputs. The probable cause effects are summarized in the following paragraphs.

A destgn feature in the DAS 1s the provision of stable excitation voltage. The problem of excltation voltage changes is normally minimized through use of a voltage regulatcr. The voltage regulator originally oonfigured with the DAS was incompatible with the UPS that was used to maintain a constant power source. The UPS was connected to the tunnel instrumentation system power line; thus, it was under continuous charge. Analyses of data from channels used to monitor excitation voltages revealed that there were unexpected varlations. Between J-Days 174 and 2.23, there was Insuffictent battery charge to malntaln stable voltages for the DCLVD'Ts. The results were visible voltage shifts in the outputs, which resulted in the variations shown in Figures 3-4 through 3-6. 
Sinco/Terrametrics and Geokon units required excitation voltages to operate. Anchor displacements were converted to voltage outputs by the sensors. The governing equation used in the data processing was

$$
D-\left\lfloor\left(E_{0} / E_{d}\right) V_{d}-V_{o}\right\rfloor S
$$

where

$$
\begin{aligned}
& \text { D - displacement position from inftialization (mm) } \\
& E_{0} \text { - excitation voltage at initialization (V) (The nominal excitation }
\end{aligned}
$$

The ratio $\left(E_{0} / E_{d}\right)$ is used to ininimize the effects of excitation voltage change during the monitoring (Zimmerman et a1., 1986) to account. for minor power varlations over long monitoring periods.

Equation 3-1 is the basic equation used in the data processing. Posttest investigations of a single sensor by SAIC revealed that Equation 3-1 was not adequate to account for all variations, and the following discussion is provided to illustrate this effect.

SAIC carefully measured the excltation voltage/output voltage relationships over the rarige of $5 \mathrm{~V}$ to $15 \mathrm{~V}$ for a single sensor and established the following equation:

$$
V_{d}-1.151 E_{d}-0.743
$$


Substitution of Equation 3-2 into Equation 3-1 yields

$$
D=\left[\left(1.151 E_{0}-0.743\left(E_{0} / E_{d}\right)-V_{o}\right)\right] S
$$

If $E_{0}, V_{0}$, and $S$ are assumed to be held constant, the change in displacement term (D) can be related to excitation voltage changes. Thus

$$
\Delta D=0.743 E_{0} S\left(\frac{1}{E_{d_{2}}}-\frac{1}{E_{d_{1}}}\right) \text {. }
$$

The DC-LVD'Ts were normally operated at $E_{0}-8 \mathrm{~V}$, and the urit conversion factor was determined to be $2.997(\mathrm{~mm} / \mathrm{V})$ (Report B). Using these quantities,

$$
\Delta D=17.814\left(\frac{E_{d_{1}}-E_{d_{2}}}{E_{d_{1}}-E_{d_{2}}}\right) .
$$

Using Equation 3-5, a variation of $\pm 1 \mathrm{~V}$ would cause $\Delta D$ to vary by $\pm 0.566 \mathrm{~mm}$. Since the voltage regulators and UPS system were not. moderating power surges, disturbances in the G-Tunnel power system could be passed to instruments. Through the years, the G-Tunnel power system has been known to have power variations on the order of $\pm 5 \mathrm{~V}$. Thus, small changes in this excitation voltage that were not prope:ly regulated with the UPS could cause measurable changes in DC-LVDT output.

\subsubsection{Evaluation}

Two 6 -anchor and six 4-anchor Sinco/Terrametrics units (DC-LVDT sensors) were installed. Of these, data from only one anchor provided problems in data reduction. The deepest anchor for Unit C7, which was inclined upward from the lower drift, apparently was not grouted adequately. The sensor for that anchor then was subjected to abnormal 
moisture conditions that caused erroneous readings. As a group, the Sinco/Terrametrics units were subjected to excitation voltage variations that normally would not occur with a stable $(<0.18)$ UPS. It is reasoned that the excitation voltages can be regulated and that the DAS operating system needs the most improvement. As an additional observation, the tensioned anchor system helped document the adequacy of the borehole grouting activities.

\subsubsection{Geokon Multiple-Point Borehole Extensometer}

Geokon MPBXs were selected for use because of two features:

(1) simplicity of electronics and (2) potential for use with short collar pipes. The sensors in the Geokon units are linear potentiometers, which have been widely used in underground measurements. Linear potentiometers are generally less sensitive to variations in power supplies. Also, untensioned anchors are more commonly used in underground measurements. Our goal was to compare measurements from a typical underground MPBX with results obtained from the more sophisticated units discussed previously.

\subsubsection{Measurement Equipment}

Geokon, Model A3, rod-type MPBXs were used (Table 3-1). The unit had six stainless-steel rods covered with Schedule 40 PVC protective tubing.

\subsubsection{Performance Observations}

Figure 3-6 shows the measurement histories for the two Geokon units. There were three measurement problems associated with the use of these units. These problems and their probable causes are summarized as follows:

(1) The data from the 2-m anchor on Unit C1 (Figure 3-6) showed intermittent electronic variations after J-Day 165 (1986). Data trends appeared to be reasonable. No cause for the variations has been found. 
(2) Data from the 5-m anchor for Unit C1 showed apparent electronic interference during the period J-Days 105-125 (1986). Posttest inspection revealed a bare wire in the head. Data trends appear reasonable if the perturbations are ignored.

(3) The sensor for the 4-m anchor for Unit C5 appeared faulty at the beginning of the measurements. The sensor was removed fxom further data logging, and data from it are not shown in Figure 3-6.

\subsubsection{Evaluation}

Two 6-anchor Geokon units were installed with horizontal orientations. of the sir anchors, data were not collected from one and two other channels showed intermittent electrical disturbances. In one case of electrical disturbance, a wire was left partially uncovered, and it is believed that the other disturbance was similarly caused. Overall evaluations of MPBXs are contained in Chapter 5 .

\subsection{Borehole Stressmeter}

There is a desire within repository-related in situ testing programs to measure stress changes within rock masses. A number of instruments are available commercially, but only devices that are not easily dislodged during blasting activities are suitable for use in excavation-related activities. A borehole stressmeter (BSM), designed as a rigid inclusion device, was used and evaluated here for Fotential use in future testing. The essence of a BSM is that force changes on a sensing device are measured and these force changes must be converted analytically or through testing programs to predicted stress changes.

\subsubsection{Measurement Equipment}

Hawkes and Bailey (1973) developed the rigid inclusion concept by fabricating a stressmeter using a vibrating wire as the sensor; the device is called a vibrating wire stressmeter (VWS). The device is wedged in a borehole. The wedging action keeps the stressmeter in place during, 
monitoring, and the stressmeter is assumed to be immovable during rock-mass vibrations induced by blasting. This condition had not been evaluated prior to these WTM evaluations, and this investigation was a developmental effort to determine if BSMs could be used in blasting environments.

Cnok and Ames (1979) redesigned the VWS units to increase the sizes of the platens and to decrease the stiffness (Report A). They used straingaged blocks to measure forces on the units. The two BSMs used in the WTM evaluations were fabricated by Specialty Engineering Associates based on the Cook and Ames design. One of the BSMs, identified as $1 \mathrm{~N}$ (Table 3-1), was installed without modification in Borehole D1 (Figure 1-2), which was $48 \mathrm{~mm}$ in diameter (AQ size). Figure 3-7a shows a diagram of the unit. The other BSM, identified as $6 \mathrm{~N}$, was modified by SAIC to fit a larger borehole (D4), which was $76 \mathrm{~mm}$ in diameter (NQ size). Borehole D4 was the same diameter as the nearby permeability holes. The larger hole required special fabrication for BSM $6 \mathrm{~N}$. The unit was modified for use by adding special bearing plates to the original unit, as shown in Figure $3-7 \mathrm{~b}$. The extra bearing plates were bonded to the smaller BSM with Hardman 5-min epoxy.

The BSMs were installed at different times. BSM $1 \mathrm{~N}$ was installed at a depth of $12.5 \mathrm{~m}$ in Borehole D1 on November 18, 1985, and was initialized in the DAS on November 22, 1985 (J-Day 326). BSM 6N was installed in Borehole D4 at a depth of $13.1 \mathrm{~m}$ and was initialized on December 18, 1985 (J-Day 352).

\subsubsection{Sensor Calibrations/Conversion Factors}

Because stresses are not measured directly with BSMs, calibrationrelated activities are discussed and sumnarized in this report. The BSM changes shape as a result of force changes on its outer surface. The changes in force are indirectly related to changes in stress in the surrounding rock through a calibration process. A necessary development in the use of the BSM in welded tuff is a caliuration process. A goal in the development of the calibration process is to mathematically relate changes in BSM voltage outputs to changes in stress in the rock. 

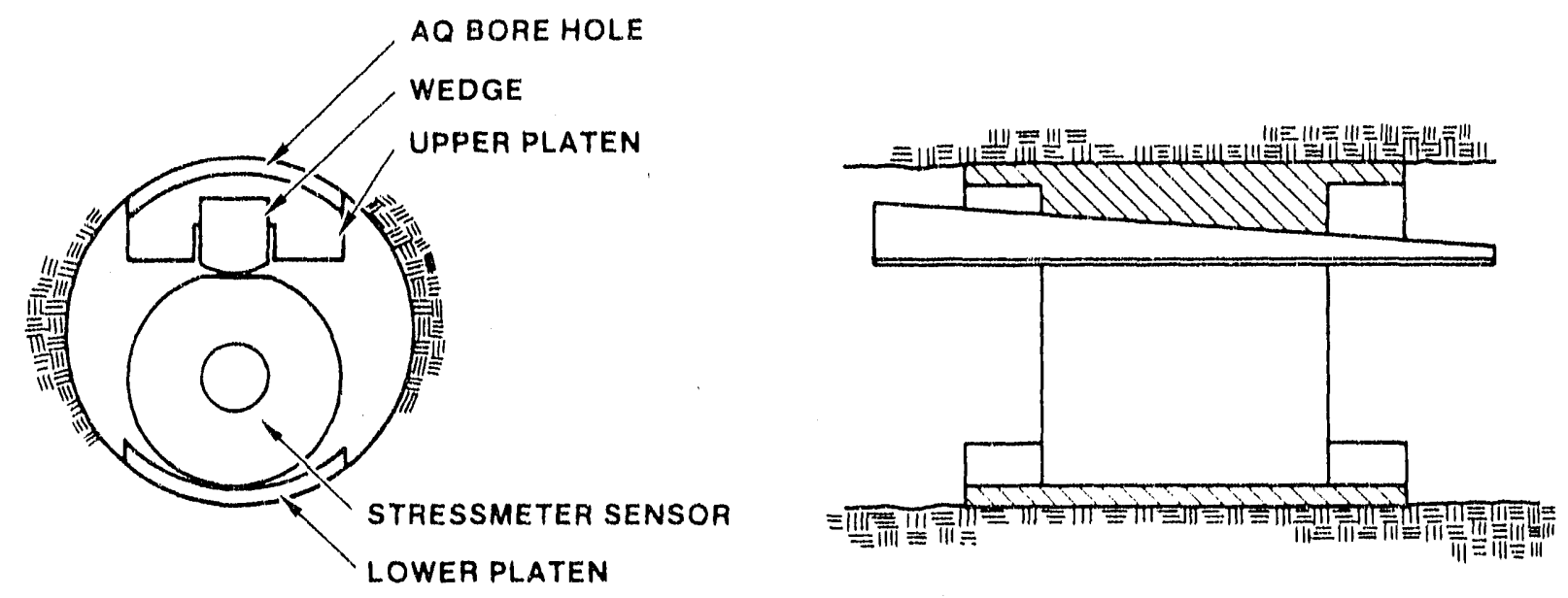

(a) AQ-Sized Hole

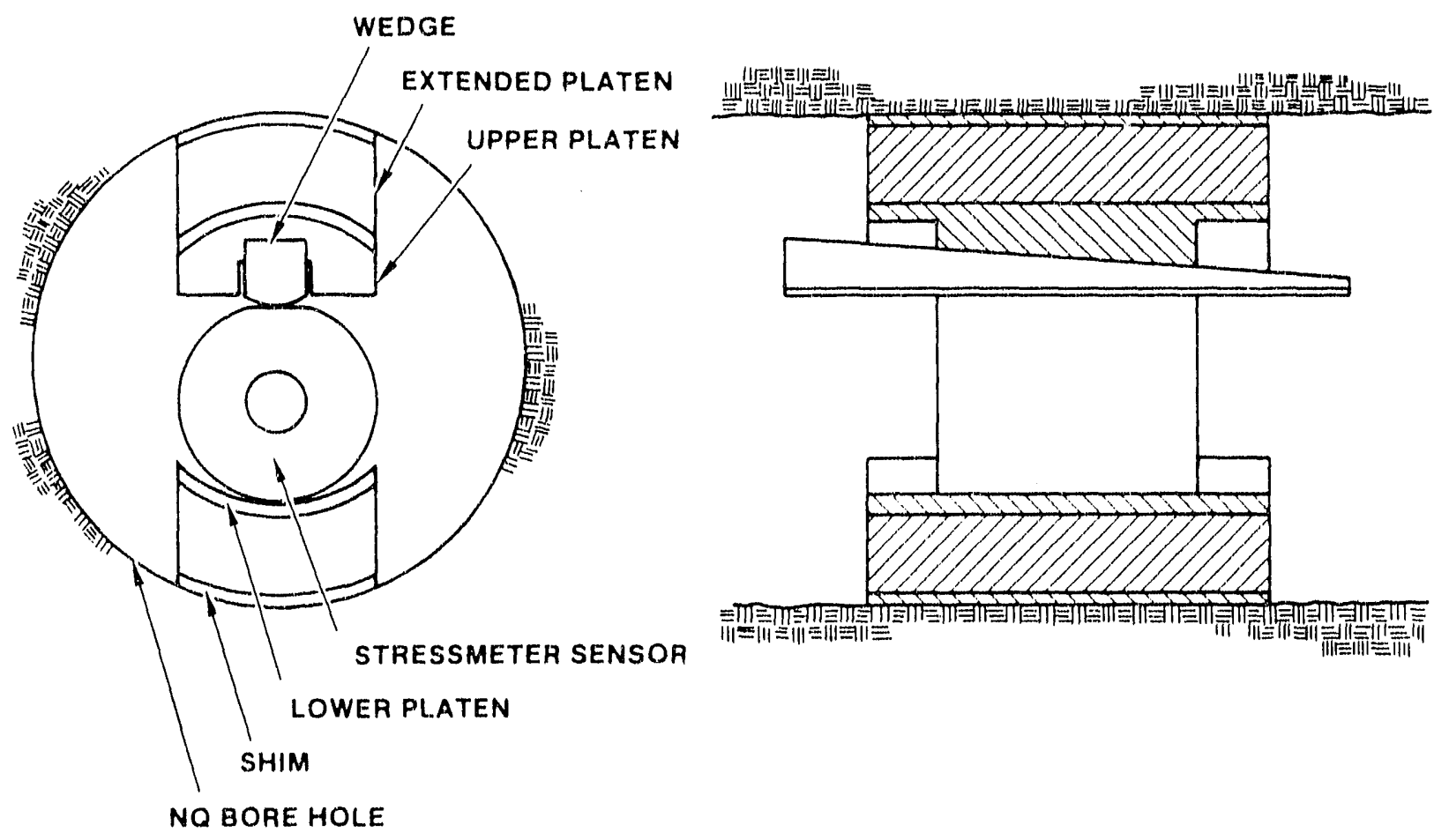

(b) NQ-Sized Hole

Figure 3-7. Schematics Showing BSM Placements 
Thompson et a1. (1986) performed preliminary investigations on developing a calibration process and proposed the values used in the WTM data acquisition system (Zimmerman et a1, 1990). They investigated possibllities of correlating changes in load across the BSM to changes in the far-field stress. Four basic loading procedures were investigated. These procedures involved: loading the BSM between two steel end pieces in two configurations, loading a block with a BSM set in a central hole, and loading the BSM in a split block. The results of the efforts by Thompson et al, are summarized here.

Both BSMs were directly loaded in a $890-\mathrm{kN}$ hydraulic servo-controlled load frame as shown in Figure 3-8a. The BSMs were loaded between two steel end pieces and a single platen (Run A). A second series (Run B) involving two platens was conducted to evaluate the repeatability factor between individual units. These loadings were not considered significant in estimating rock mass responses because of lack of direct interaction between the BSM and a borehole surface.

Table 3-2 summarizes the results of the measurement efforts for the firsi series (Runs $A$ and $B$ ). Maximum forces were $27 \mathrm{kN}$ for these runs. The table provides the conversion factor, which represents the slope of a line, and the standard deviation, which represents the variance in the ordinate parameter (N) with respect to the line based on a linear regression.

Table 3-2. Summary of Conversion Factor Measurements

\begin{tabular}{|c|c|c|c|c|c|}
\hline \multirow[b]{2}{*}{ Series } & \multirow[b]{2}{*}{$\underline{\text { Run }}$} & \multicolumn{2}{|c|}{ BSM $1 \mathrm{~N}$} & \multicolumn{2}{|c|}{ BSM 6N } \\
\hline & & $\begin{array}{l}\text { Conversion } \\
\text { Factor }(\mathrm{N} / \mathrm{mV})\end{array}$ & $\begin{array}{c}\text { Standard } \\
\text { Deviation (N) }\end{array}$ & $\begin{array}{l}\text { Conversion } \\
\text { Factor }(\mathrm{N} / \mathrm{mV})\end{array}$ & $\begin{array}{c}\text { Standard } \\
\text { Deviation }(\mathrm{N})\end{array}$ \\
\hline Direct & A & 2,717 & $\pm 1,710$ & 2,430 & $\pm 4,187$ \\
\hline Loading & B & 2,427 & \pm 982 & 2,635 & $\pm 3,466$ \\
\hline $\begin{array}{l}\text { Split } \\
\text { Block }\end{array}$ & $\mathrm{C}$ & 4,336 & \pm 406 & 2,427 & $\pm 1,088$ \\
\hline
\end{tabular}




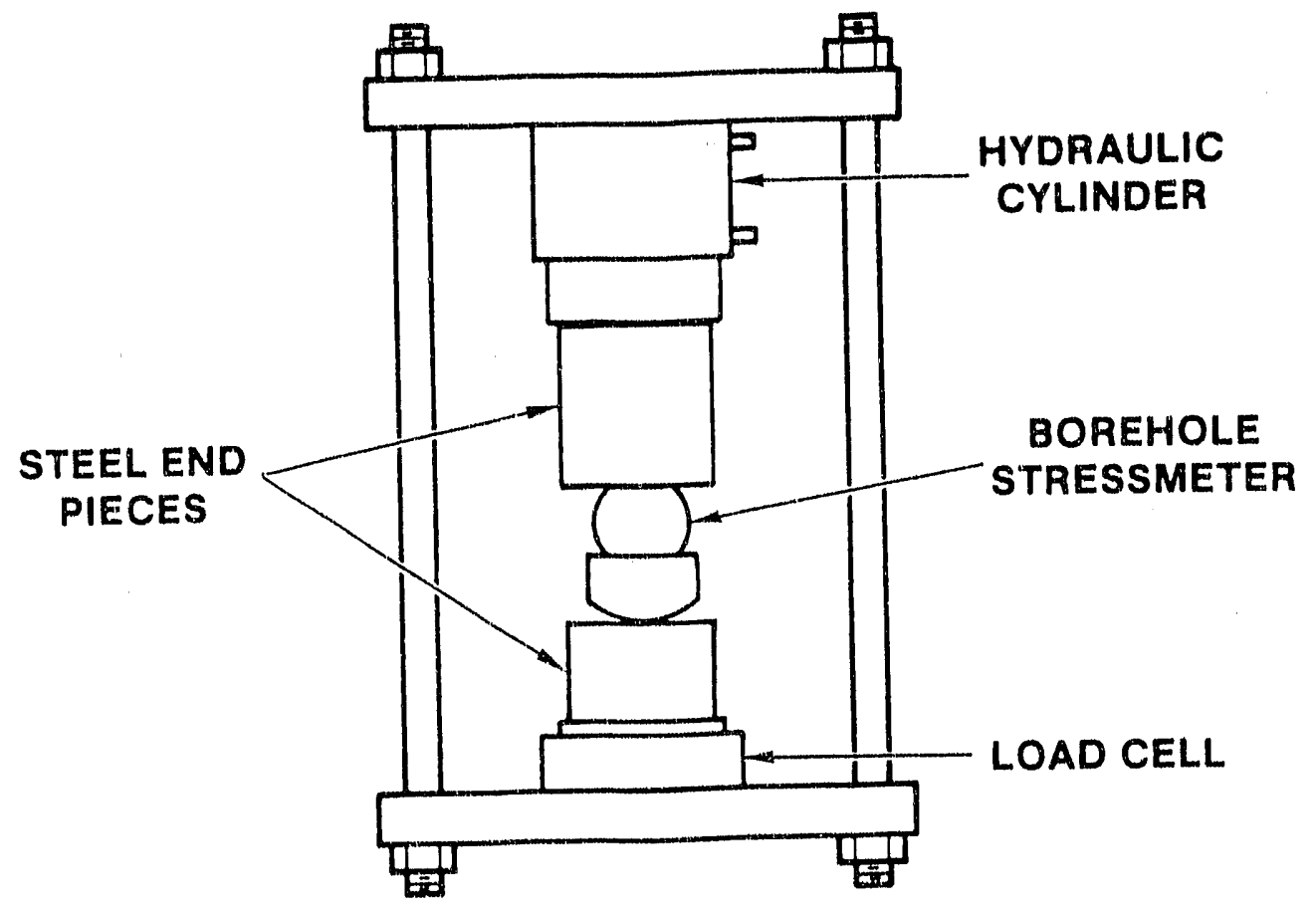

(a) Direct Loading

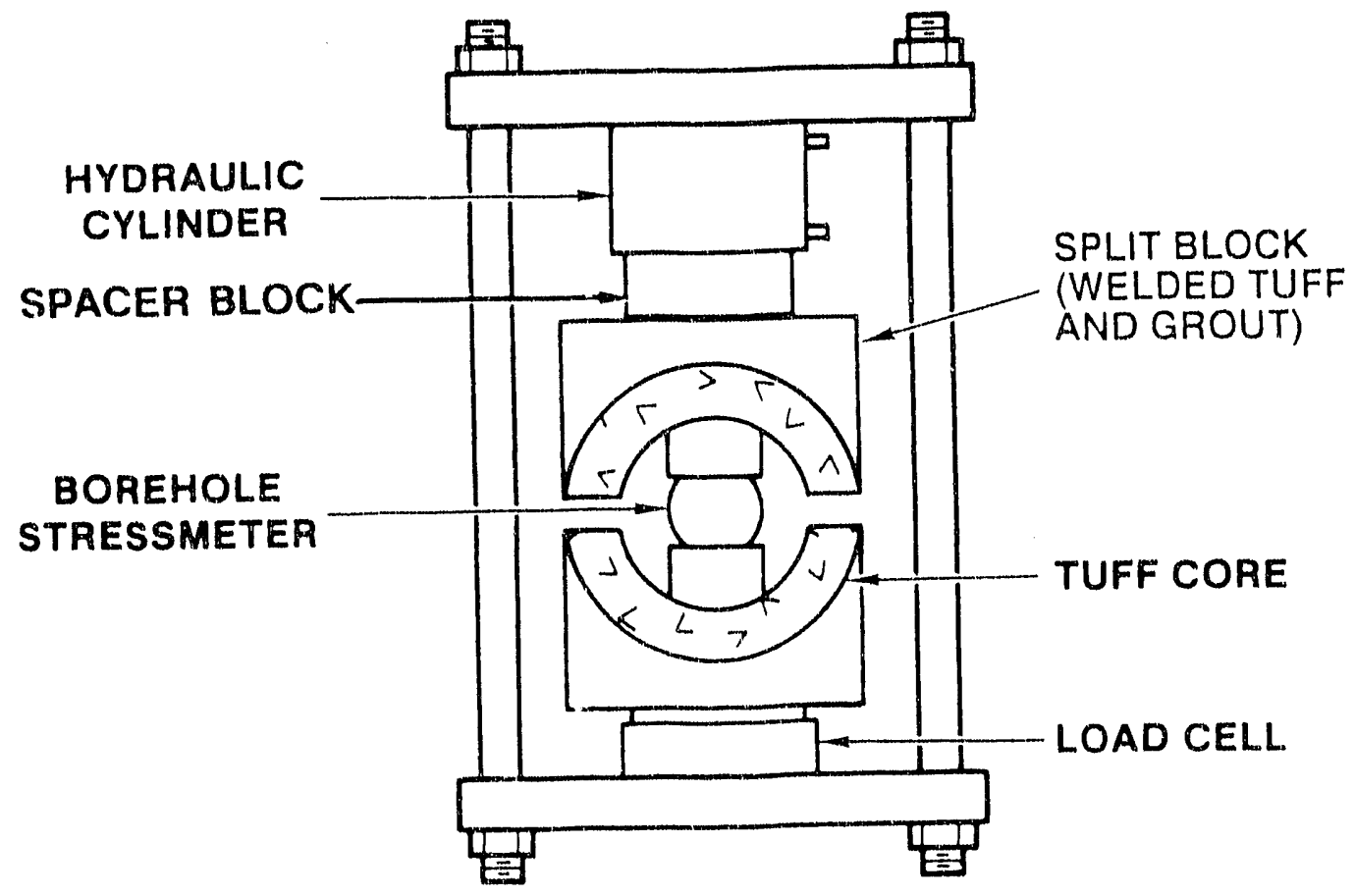

(b) Split Core Loading

Figure 3-8. Schematics Showing Loading Methods for BSM Calibrations 
The second series was directed towards establishing relations between BSM force changes and far-field stress changes. Two solid blocks were prepared using blocks made of tuff and grout. The blocks were made of tuff cores and grout was added to make them square. The intent was to try to represent the borehole configuration in the welded tuff. This was attempted because tuff is much harder than the salt used in the earlier studies by Cook and Ames (1979). A block falled during this testing and a third series was designed with a split-block configuration (Figure 3-8b).

Measurements in the split-block configuration were conducted in a manner similar to the procedures used by Cook and fmes (1979) for establishing experimental relationships between external rock forces and sensor outputs. Table 3-2 shows results of the best of the split-block tests (Thompson et a1., 1986) for each BSM. Maximum forces were $54 \mathrm{kN}$ for these tests. The table shows: (1) considerable scatter in the data and (2) significant differences in the conversion factors for the different size units. Table 3-2 shows that the conversion factors for individual sensors were similar (Runs $A$ and $B$ ) while the differences in split-block test configurations (BSMs $1 \mathrm{~N}$ and $6 \mathrm{~N}$, Run $\mathrm{C}$ ) varied by nearly 808 .

The conversion factors in Table 3-2 are not considered to be accurate calibration factors. Such factors as: hardness of tuff; difficulties in mating a BSM to a rigld borehole surface; difficulties in obtaining large blocks of welded tuff; and budget limitations prevented us from pursuing a better calibration program. We felt that qualitative values would be useful in establishing a proof-of-concept for use of BSMs in a blasting environment. Thus, quantitative values used in calibration files for the WTM measurements are considered to be mathematical conversion factors, but not calibration factors.

The actual conversion factors used in the DAS were based on the split block measurements because these procedures were considered the most compatible with fleld applications. The values used were 
iN $\quad 4,330 \mathrm{~N} / \mathrm{mV}$ (stmplified from 4,336 )

$6 \mathrm{~N} \quad 2,425 \mathrm{~N} / \mathrm{mV}$ (simplified from 2,427 )

\subsubsection{Performance Observations}

Figure 3-9 shows the force history plots for the two BSMs. The BSMs measured force changes in a vertical plane oriented along the axes of the boreholes. The inftial values represent the forces calculated using strain-indicator readings obtained during the installation process, which were $14,420 \mathrm{~N}$ for BSM $1 \mathrm{~N}$ and a lower value of $8,940 \mathrm{~N}$ for BSM $6 \mathrm{~N}$ because of the poor installation location (Report A).

The plots in Figure 3-9 show data spikes around J-Day 263 and J-Day 277 (1986) that were due to the power losses discussed previously. The figure also shows the times for blasts in the Demonstration Drift. Some jumps in the BSM outputs can be correlated visually to blasting activities. BSM IN showed responses to blasting activities as the mining progressed through Station D. The results show that (1) BSM $6 \mathrm{~N}$ was relatively insensitive to the blasts and (2) both BSMs showed a time-dependent loss of force.

The reason for the insensitivity for $B S M 6 \mathrm{~N}$ is belleved to result from the installation difficulties. Even though the BSM was successfully located in the borehole, it was apparently not installed we11 enough to properly engage the rock. It is possible, but highly unlikely, that the BSM was installed in a small isolated block in the vitrophyre and that the stress fields were not changing as a result of the excavations.

The performance of the BSMs somewhat follows the performance reported by Johnstone et a1. (1985). Their BSMs were used in a heating and cooling cycle, and $i t$ was noted that the final readings were less than the initial readings. They postulated that the declines could be a result of creep relaxation under the platens or slight adjustments in the rock mass surrounding the units. 


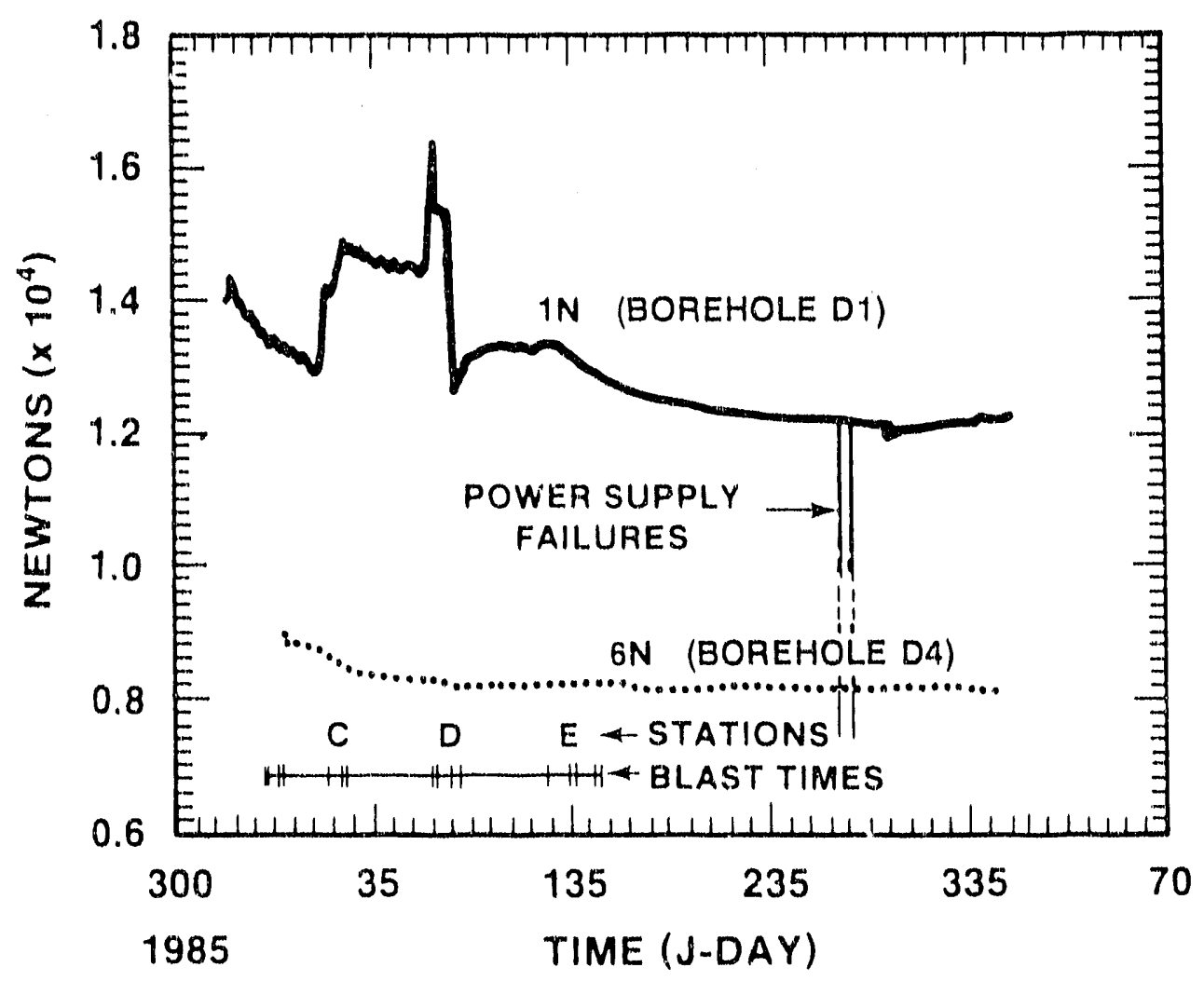

Figure 3-9. Force Histories for BSMs 
It was not readily apparent whether the timendependent loss of force In the BSMs was due to Instrumentation problems, creep and/or stress redistribution th the rock, or molsture. Molsture effects were considered important because of problems with other straln"gage-based Ingtrumentation and they were investigated.

SAIC finstalled "BSM In a ste日l. plpe and monltored the slgnal output for more than 30 days. There was no resulting loss of force. In another effort, SAIC placed a BSM in a steel cylinder for 13 days then placed the entire assembly in a sealed enclosure and subjected tt to conditions of 100 relative hunldity for 70 days. The 100 humidity was to represent the enviromental condition prevalent in the GTUF. Results showed a nearly Inear decrease In signal output of approximately $11 \mu \mathrm{V} /$ day after insertion in the high-humidity enviroment. This amounted to a 58 loss of signal for: this period. The time perfod for the latter experiment was relatively short, but the potential effects of molsture were clearly evident.

\section{2 .4 Evaluation}

Information in this section has shown that potentially useful data were recorded from one of the two BSMs during the blasting. Data from BSM IN showed some senstivity to the excavation process, and results could be used to estimate qualitative force changes, From an instrumentation standpoint, the BSMs were dlfficult to calibrate and some installation difficulties occurred. The results presented here and those presented by Johnstone et a1. (1985) suggest that there are problems in using the units for long-term monitoring. Potentials for loss of data fn a nominality unsealed strain-gage-based instrument located in a high-relative-humldity environment were established.

The discussion in this report points out a basic limitation to the use of BSMs in welded tuffs. At this time a valid calibration process has not been developed. Calfbration efforts must include studies destgned to address experimental problems: (1) in nonlinear behavior, probably due to "bedding in" of the BSM surfaces, (2) In use of compostle blocks of grout and tuff, (3) in establishing proper staes of blocks, the latter sometimes 
1.mited by testing machine capabliftes, and (4) fon controlifng potential. moisture problems.

\subsection{Book Bolt Load Cell}

Rock bolt load cells (RBLCs) normally are used to monltor: changes in forces on rock bolts that occur as a result of displacements in the neatby rock mass. They serve as useful monttoring devloes in evaluating some aspects of underground safety. They were used here, In a scheme considered for ES testing, to augment the MPBX system.

\section{3,3,1 Measurament Equipment:}

Rock bolts are tensioned steel reinforcing bars (rabars) that are placed in percussion drilled holes in the rock mass. The rebars are bonded to the rock and are attached to base plates that transmit the tightening forces to the rock surroundlng the holes. For measurements, an RBLC $1 \mathrm{~s}$ placed at the onl of a selected rock bolt to measure the resultant force that is transmitted to the base plate.

Ordinarlly, RBLCs are applied under conditfons fn which the rock bolts are anchored on the ends and the tenstle forces are distributed between the base plates and the anchors. In vlew of safety considerations in the G'tuF, the rock bolts were fully grouted. Thus, it is assumed that only a fraction of the total force transinted to the rock bolt was diatributed to a base plate. This means that the RBLCs could be expected to be only partially effective in measuring displacements in the rock mass.

Sinco/Terranetrics, Mode]. PC-60, steel. undts were selected for the measurements ('l'able 3-1). The units have a capacity of $535 \mathrm{kN}(120,000$ lbf) with a nomlnal senstulvity of $\pm 267 \mathrm{~N}$ (60 lbf). Sixteen unlts were purchased for the evaluatlons. Four RBLCs were fnstalled on roof rock bolts at each of two stations, as fllustrated In Figure 3-10.

The remainlng elght: RBLCs were posttioned on grout inserts that contained hydraulde pressure cells (HPCs) and only the bottom 30 cin of the rock bolts were anchored. The Inserts were cast in the sldes of the 


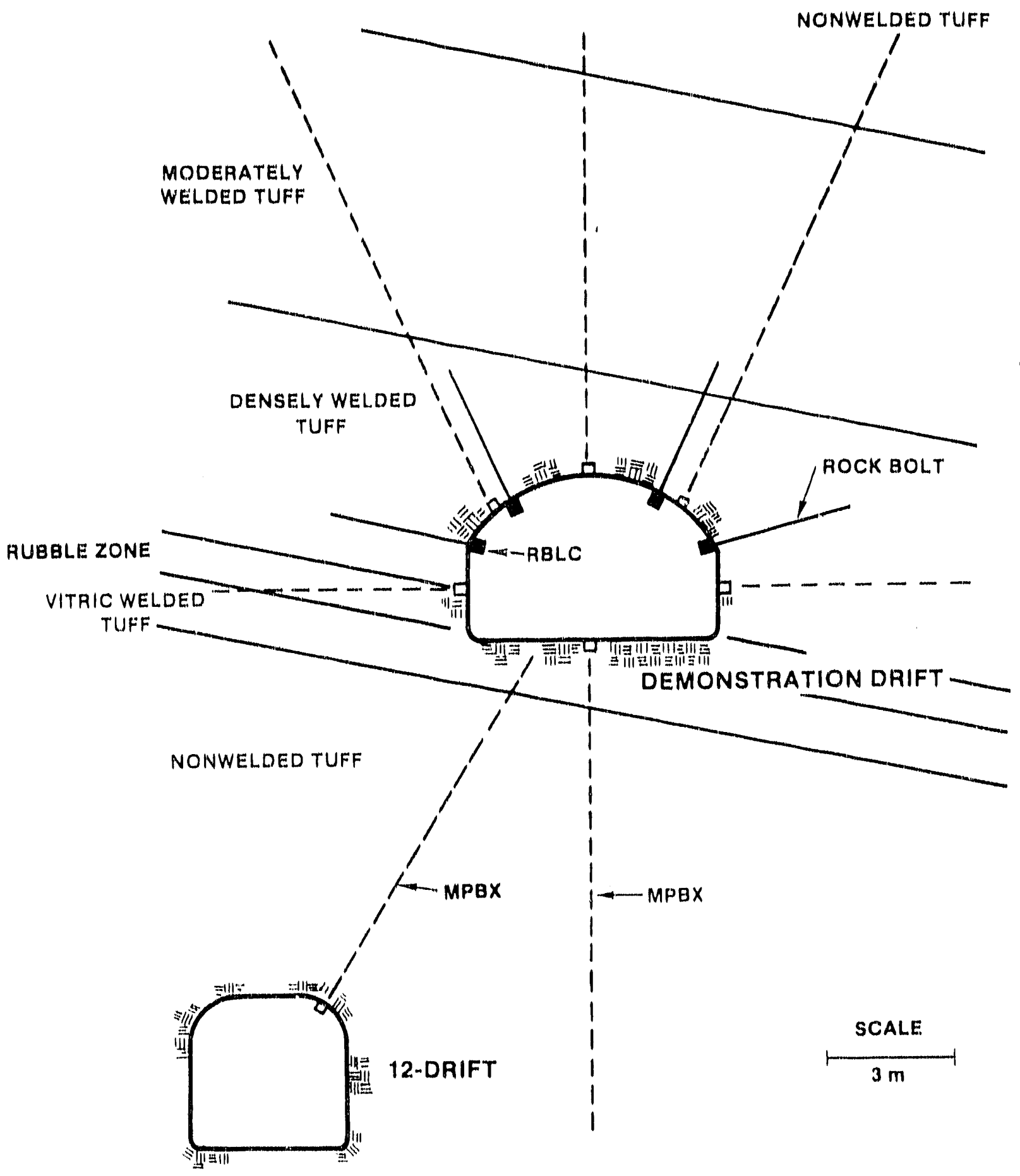

Flgure 3-10. Elevation View Showing RBLC Layout 
Demonstration Drift for HPC evaluations, and RBLCs were applied to surfaces of the inserts to plck up any load that the inserts ind ght recelve. A goal was to observe whether RBLC load changes were compatible in a qualitative sense with pressure changes in the HPCs. Flgure 3-11 shows plan and elevation vlews 11.1ustrating the placement of the RBLCs on one of the inserts.

The use of RBLCs in fractured rock suggested the need to consider proper load cell alignment. The base plate bearing agalngt the uneven rock surface can cause the RBLC and rock bolt to be out of 1 ine, resulting in bending stresses in the rock bolts and possibly the RBLCs. The potential problem was addressed by grouting the base plates to the rock and by providing a spherical seat between the rock and the RBLC tension plate (Report A).

\subsubsection{Performance Observations}

RBLC Units $1-4$ were installed and initialized at Station $C$ on April 29, 1986 (J-Day, 121). Units 5.8 were similarly installed at Station E on Apr11 30, 1986 (J-Day 122). The next blast at the E face was on J-Day 122. With this sequencing, the effects of the blast at stations located both near and relatively far from the blast could be studied. The blast effects on Untes 5-8 (Channe1s 76.82) are shown in Figure 3-12. The blast effects observed In Units 7 and 8 are assumed to be changes in the rock mass near the cover plate because of the permanent nature of the force changes. The posstbility exists that elther a plece of rock hit the Unit 7 apparatus or there was a small rock readjustment buhind the cover plate.

The remaining eight RBLCs were installed on the grout inserts on September 10, 1986 (J-Day 253). RBLC Units 13-16 were partially tightened on September 10 and then tightened further on September 11, 1986, to determine the effects of sequential tightening. Figure $3-13$ shows the effects of the tightening.

Figures $3-14 \mathrm{a}$ and $3-1.4 \mathrm{~b}$ show the RBLC load histordes for the roofmounted unfts. Flgure 3-14a shows the load histories for the four units 


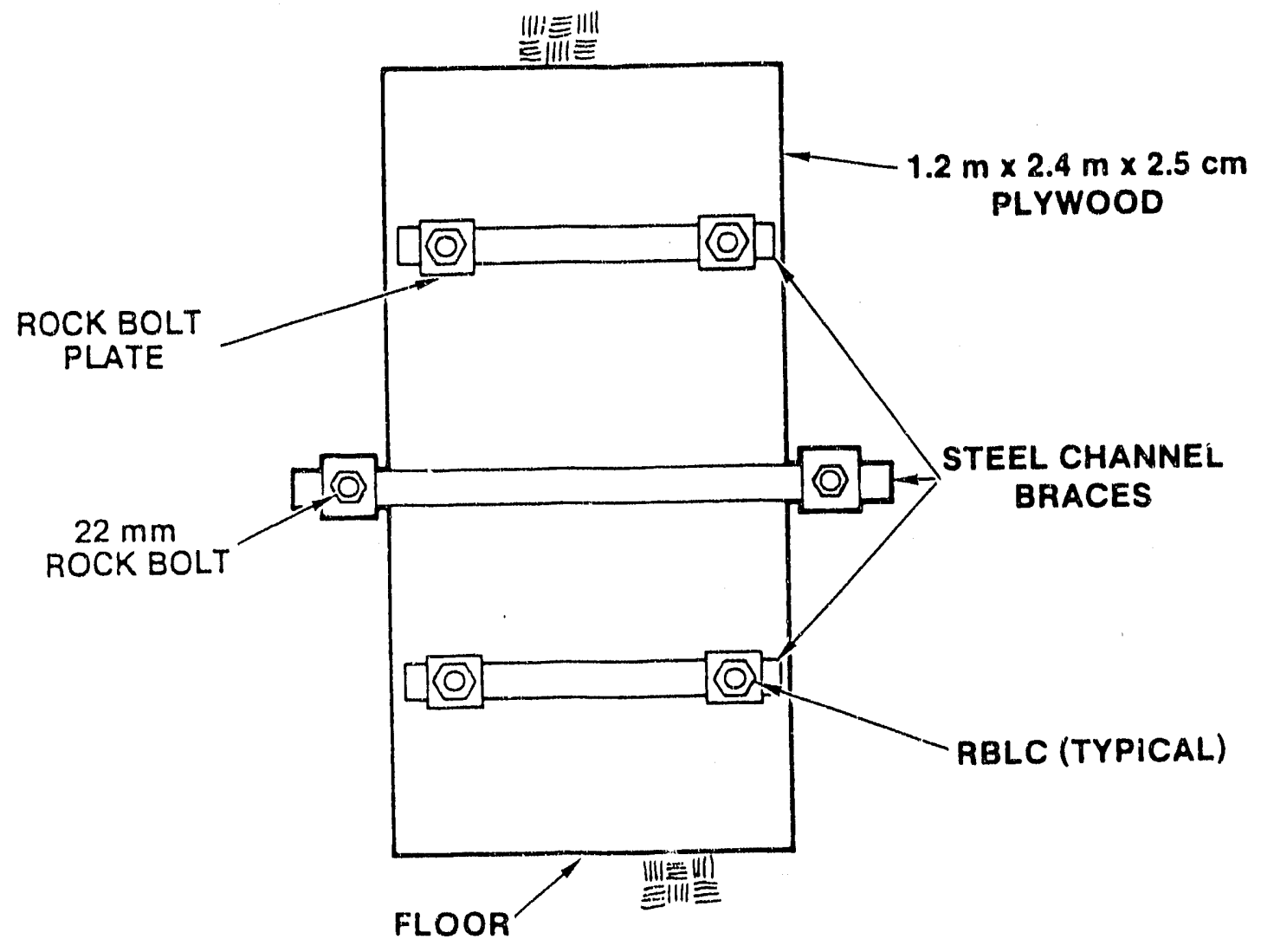

ELEVATION VIEW

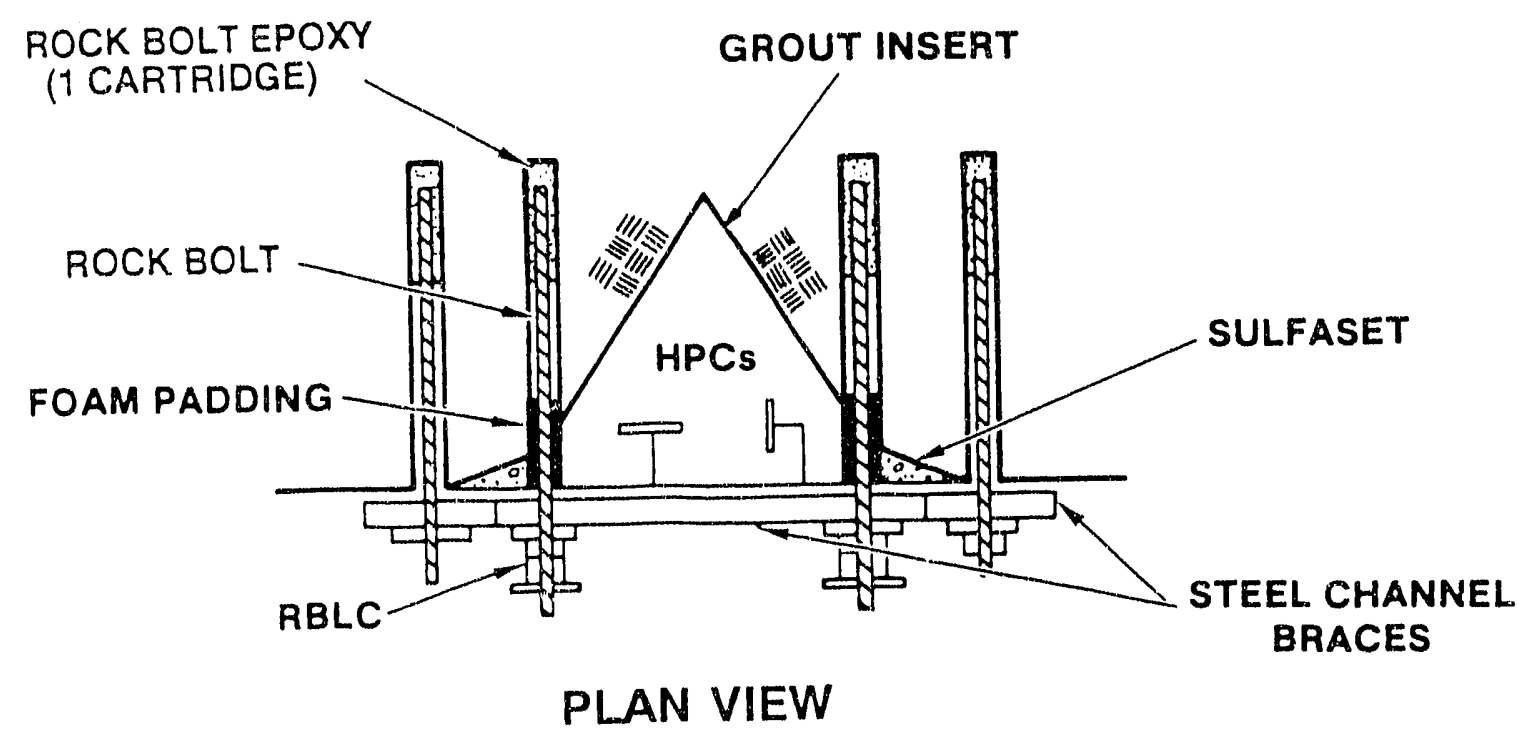

Figure 3-11. Configuration of Pane1 Before Grouting 


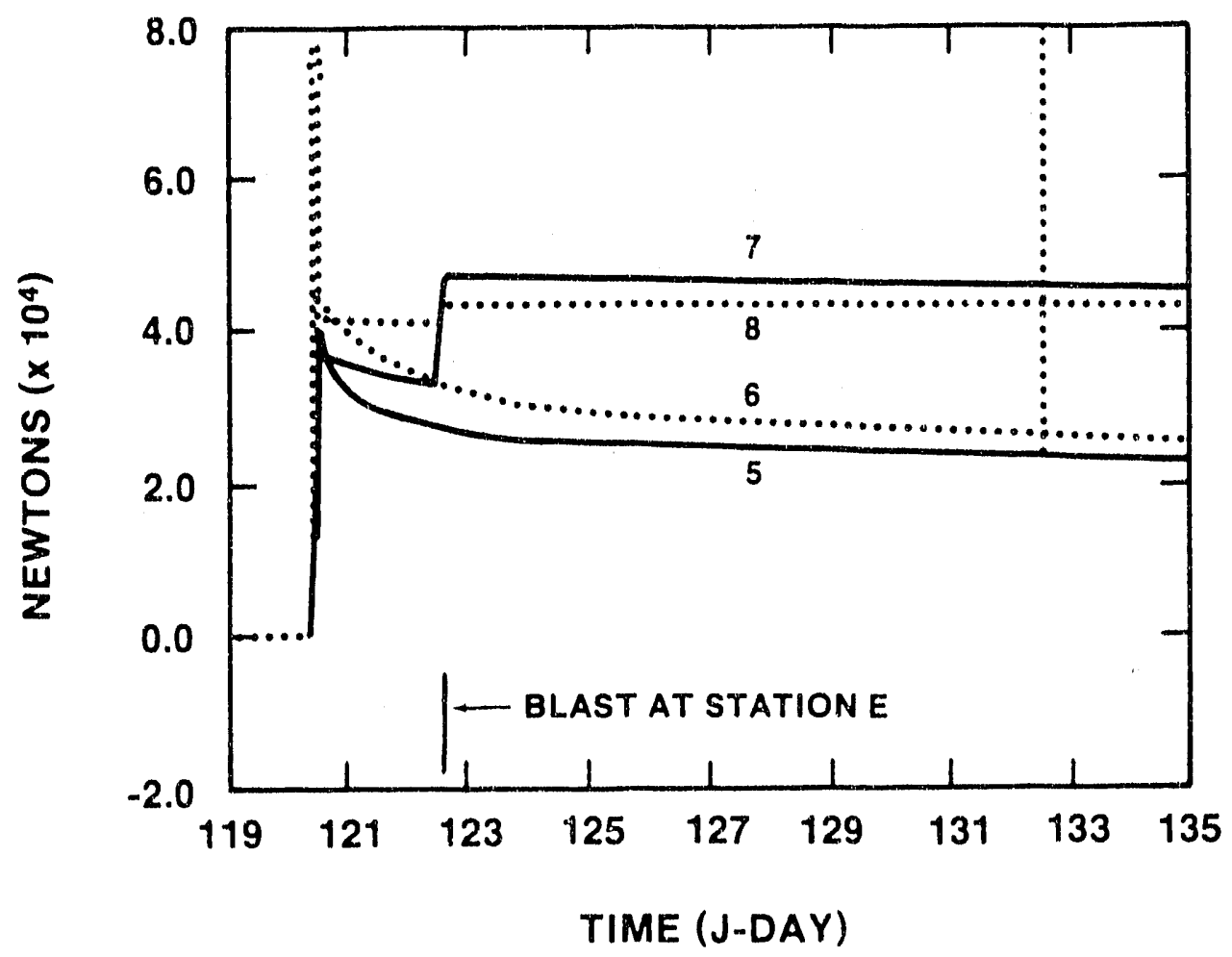

Figure 3-12. Force Histories for RBLC Units 5-8 at Station E Showing Changes Resulting from a Blast

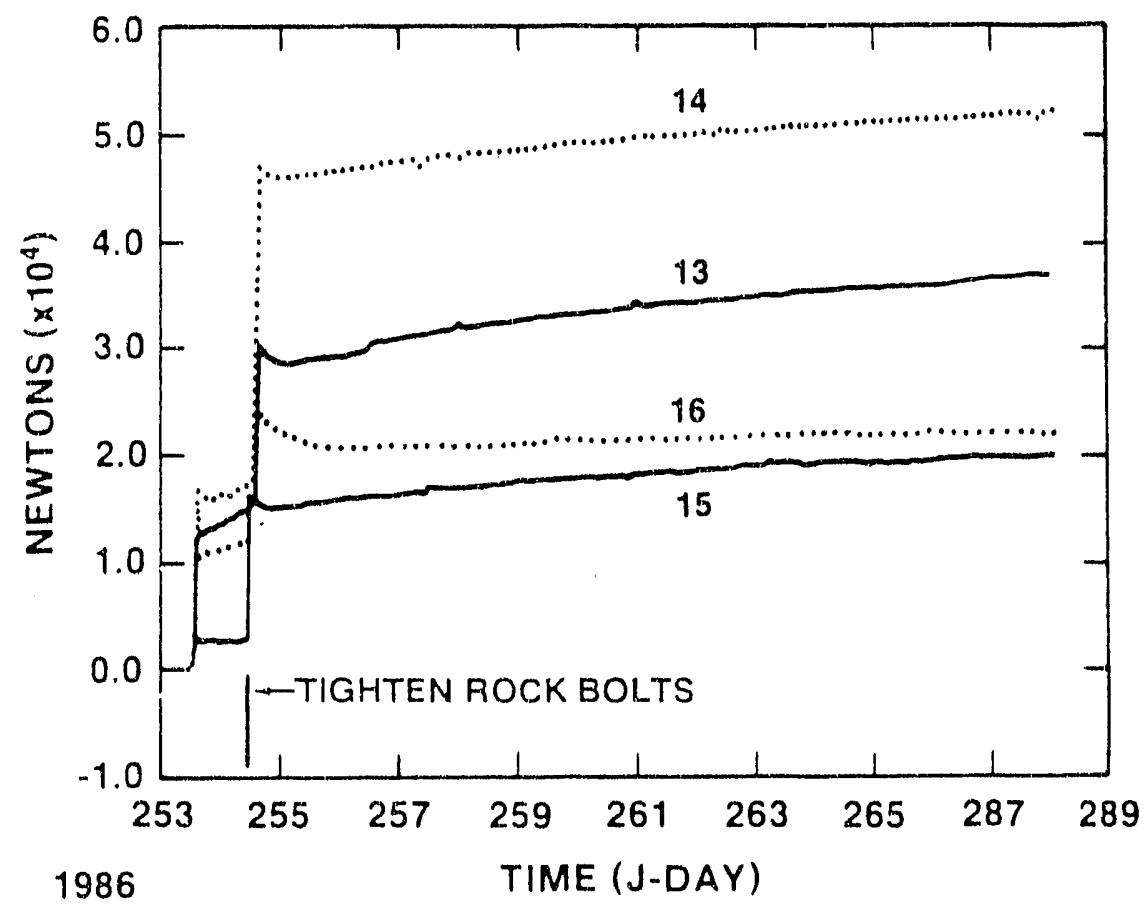

Figure 3-13. Force Histories for RBLC Units 13-16 at Grouting Insert Showing Sequential Tightening Effects 


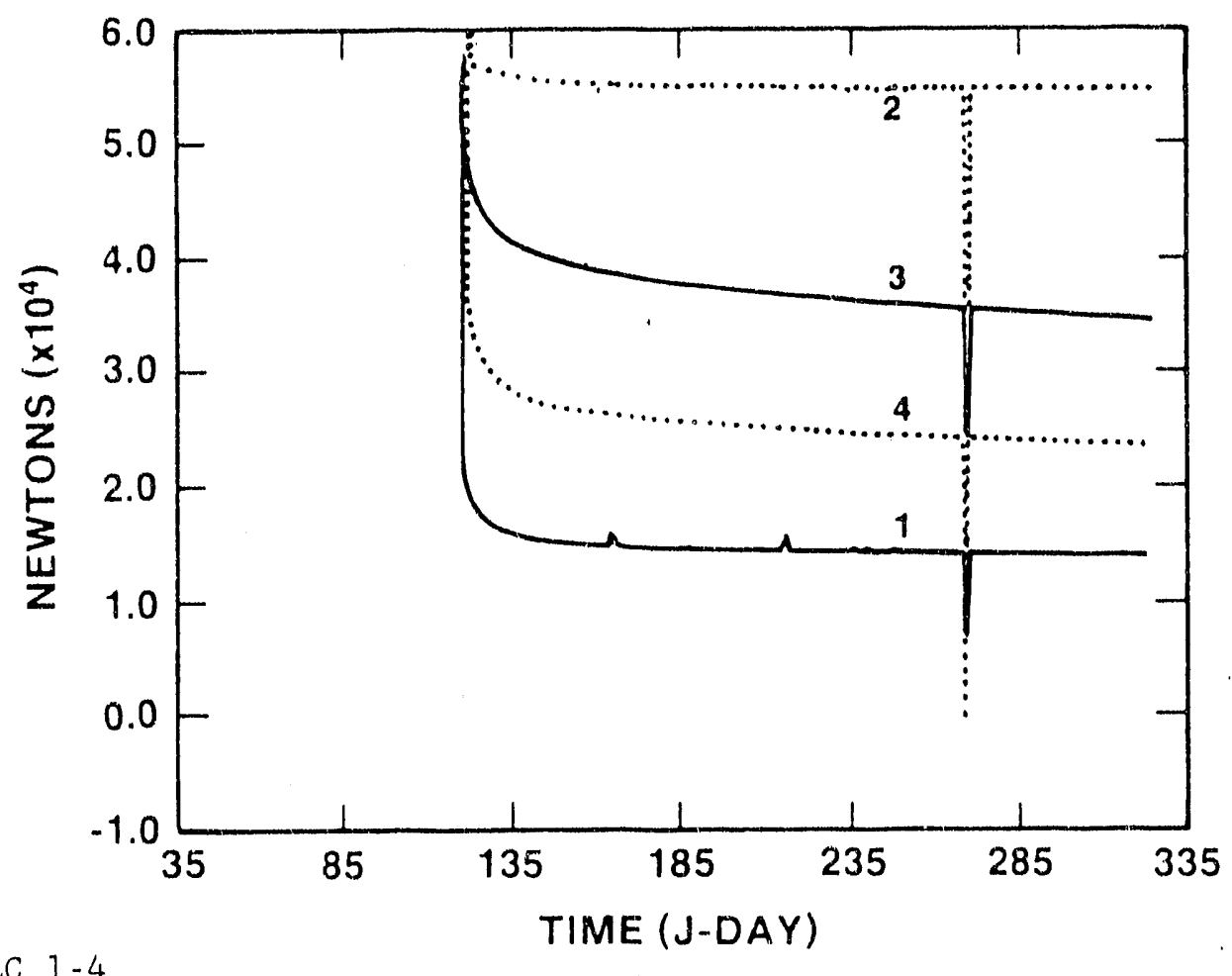

(a) RBLC 1-4

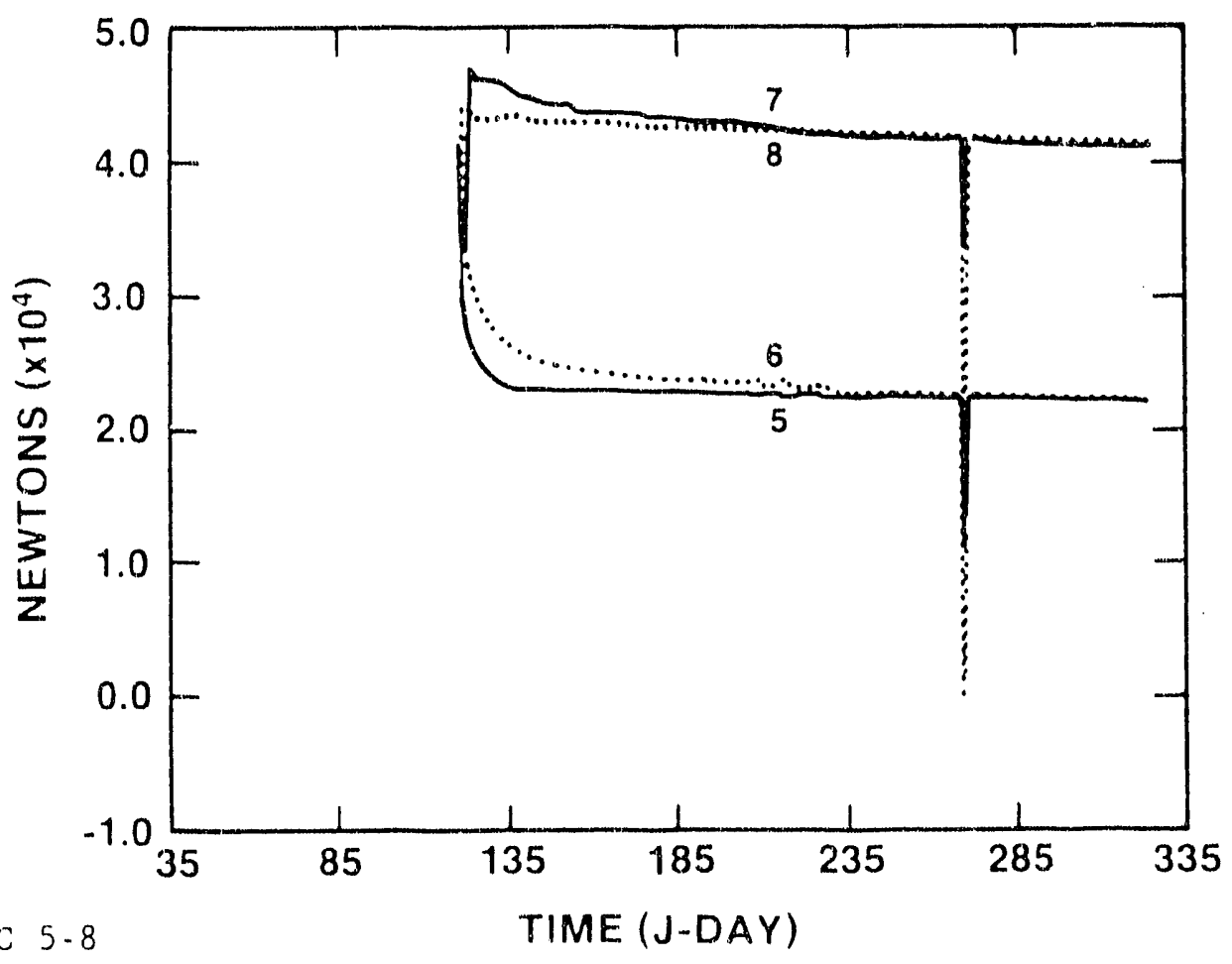

Figure 3-14. Long-Term Force Histories for RBLC Units 1-8 
mounted at Station $C$, and Figure $3-14 \mathrm{~b}$ shows similar histories for Station E. Data splkes have been discussed previously. These long-term plots show relatively uniform load decreases on the order of $1-2 \times 10^{4} \mathrm{~N}$. Using the rock bolt spacing as the influenced area, this magnitude corresponds to a stress decrease of approximately $10 \mathrm{kPa}$. It is quite possible that the decreases were due to a relaxation between the RBLC and the nearby rock. The relaxation also could be a result of creep in the resin grout. The authors were unable to determine the cause.

Figures 3-15a and 3-15b show the load histories for the eight units located on the grout inserts. The trends indicated small load increases after installation. The grout inserts were made with an expansive grout. The measurements suggest that the grout inserts were being loaded slightly.

\subsubsection{Evaluation.}

The RBLCs performed well, and there were no instrumentation-related irregularities observed in the measurements. The RBLCs performed adequately during the blasting activities from a data-recording standpoint. Data interpretations were difficult, however. Two units showed changes that were related to the blast, but the authors were unable to ascertain if changes were due to rock mass adjustments or instrumentation variations. This situation could be improved if strain gages were added to the grouted rock bolts. Also, all gages in the roof showed some time-dependent relaxation. 


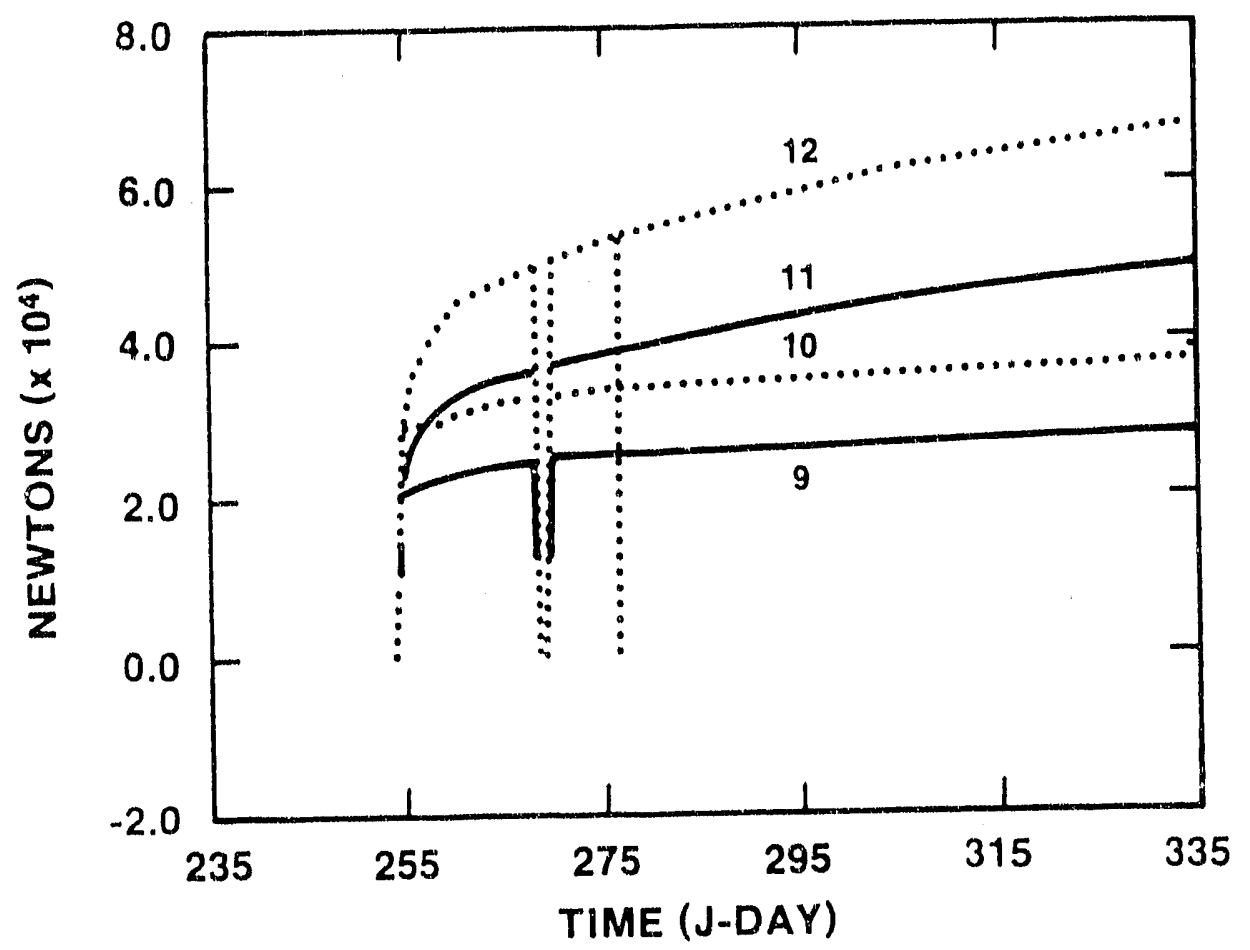

(a) RBLC 9-12

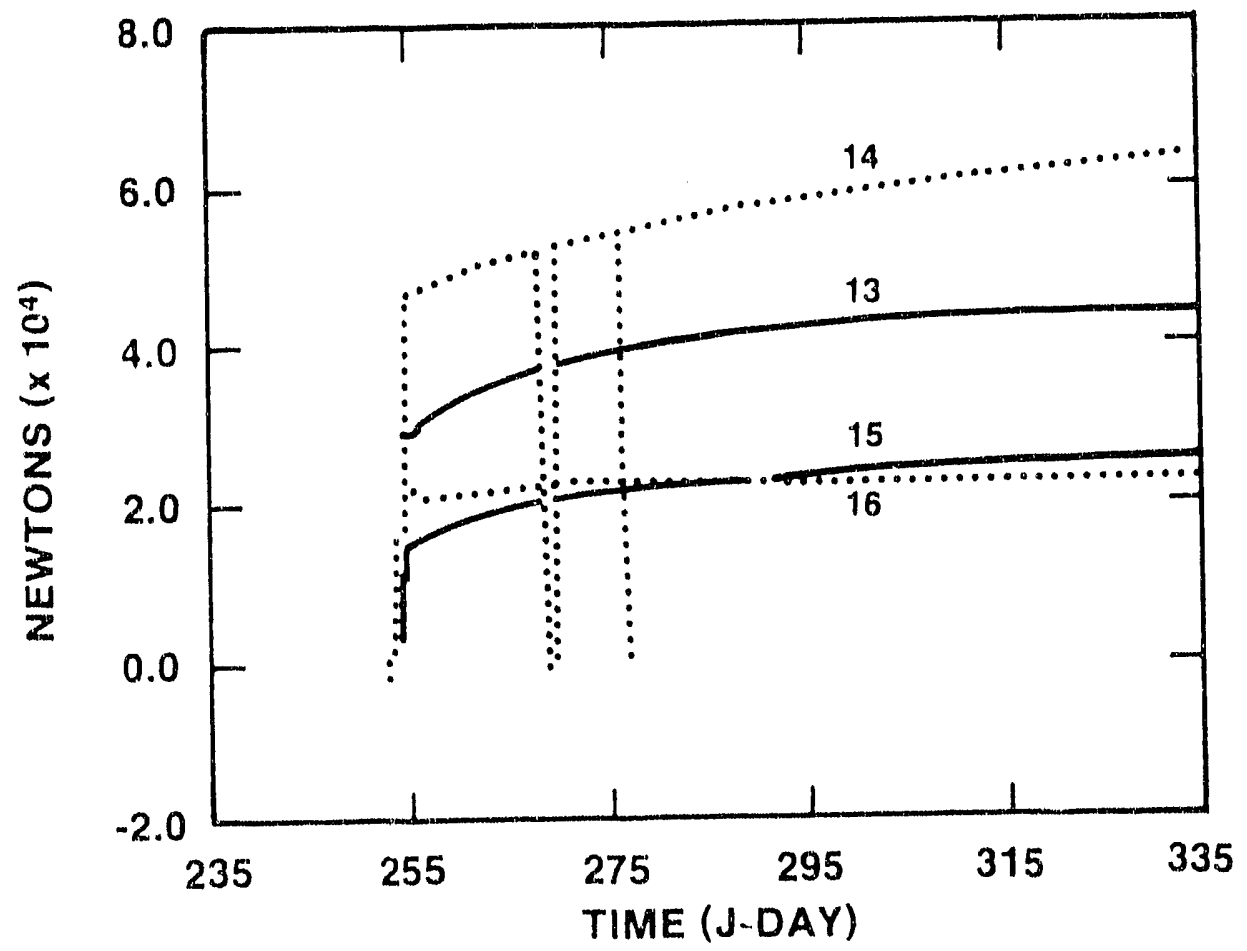

(b) RBLC $13-16$

Figure 3-15. Long-Term Force Histories for RBLC Units 9-16

$$
3-37 / 3-38
$$




\subsection{MANUAL MEASUREMENT DESGRIPTIONS AND EVALUATIONS}

This chapter introduces, describes, and evaluates the manual measurements.

\subsection{Tape Extensometer}

A steel tape extensometer (TE) is a standard instrument for measuring drift convergence. A TE had been purchased for another experiment and had worked well. This was included in test planning as an available tool and a tape convergence measurement system was designed. TE stations were set at. the end of nearly every blast round, and measurements were taken as the mining face advanced. Measurement equipment and performance observations are discussed in this section.

\subsubsection{Measurement Equipment}

A TE measurement was a direct measurement of the distance between two anchors located on opposite sides of the Demonstration Drift. The measurement was made using a special steel tape and an apparatus containing a dial indicator. Figure 4-1. illustrates a typical measurement.

A Sinco/Terrametrics TE was used for all measurements (Table 2-2). It has a precision steel tape perforated at fixed intervals and a dial indicator capable of reading to $0.025 \mathrm{~mm}$. The TE has a special tensioning device that is used to ensure that the same tension is applied at each reading. With the tensioning device, leadings are accurate to $\pm 0.13 \mathrm{~mm}$, according to the manufacturer.

Measurements were made between anchors fabricated from $22-\mathrm{mm}-\mathrm{dia}$ rebar with eyelets attached at the measurement ends. The SAIC-fabricated anchors were epoxied into percussion-drilled holes along a $38 \mathrm{~cm}$ length, with the eyelets recessed to prevent possible damage from blasting. 


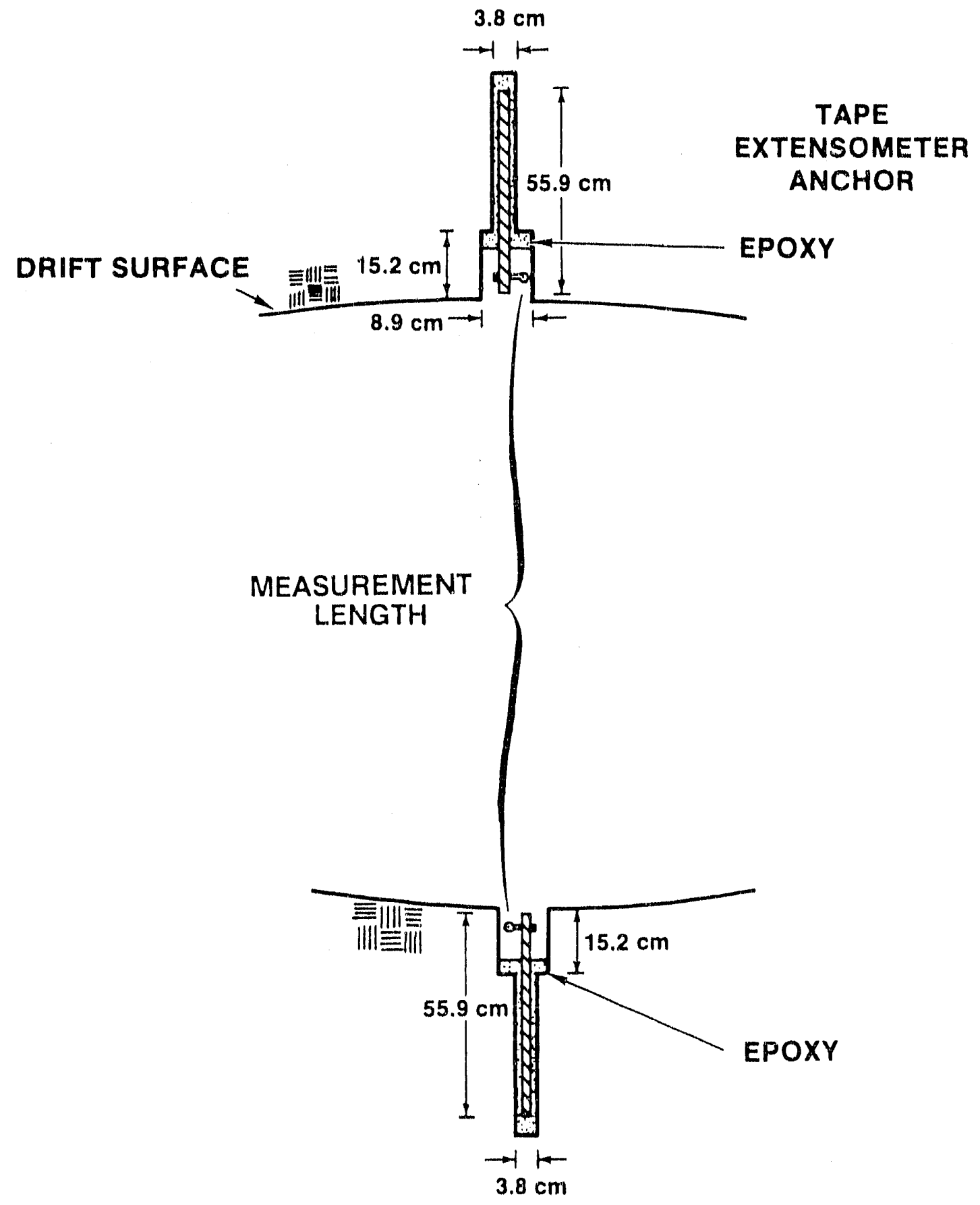

Figure 4-1. Tape Extensometor Measurement Arrangement 
Table 4-1 gives the anchor stations and the fintial measurements. Note that no horizontal convergence station was set at Station I because of lack of solid rock at the destred measurement location.

Table 4-1. Intial Convergence Station Measurements

\begin{tabular}{|c|c|c|c|c|}
\hline \multirow[b]{2}{*}{ Station } & \multirow[b]{2}{*}{ Direction } & \multicolumn{2}{|c|}{ Date Initialized } & \multirow{2}{*}{$\begin{array}{l}\text { Measurement: } \\
\text { (m) }\end{array}$} \\
\hline & & Date & J-Day & \\
\hline AlV & Vertical & $12 / 9 / 85$ & 343 & 3.458 \\
\hline A2V & Vertical & $12 / 9 / 85$ & 343 & 3.828 \\
\hline BV & Vertical & $1 / 13 / 86$ & 13 & 4.126 \\
\hline $\mathrm{CV}$ & Vertical & $1 / 24 / 86$ & 21 & 4.121 \\
\hline DV & Vertical & $3 / 12 / 86$ & 71 & 4.174 \\
\hline EV & Vertical & $4 / 15 / 86$ & 105 & 4.013 \\
\hline FV & Vertical & $5 / 6 / 86$ & 126 & 3.911 \\
\hline GV & Vertical & $5 / 13 / 86$ & 133 & 3.994 \\
\hline HV & Vertical. & $5 / 20 / 86$ & 140 & 3.840 \\
\hline IV & Vertical & $5 / 28 / 86$ & 148 & 3.832 \\
\hline JV & Vertical & $5 / 30 / 86$ & 150 & 4.063 \\
\hline $\mathrm{BH}$ & Horizontal & $1 / 14 / 86$ & 14 & 6.064 \\
\hline $\mathrm{CH}$ & Horizontal & $2 / 27 / 86$ & 58 & 6.218 \\
\hline $\mathrm{DH}$ & Horizontal & $3 / 12 / 86$ & 71 & 6.105 \\
\hline $\mathrm{EH}$ & Horlzontal & $3 / 26 / 86$ & 85 & 6.186 \\
\hline $\mathrm{FH}$ & Horizontal & $5 / 6 / 86$ & 1.26 & 5.900 \\
\hline $\mathrm{GH}$ & Horizontal & $5 / 13 / 86$ & 133 & 5.985 \\
\hline $\mathrm{HH}$ & Horizontal & $5 / 20 / 86$ & 140 & 6.228 \\
\hline $\mathrm{JH}$ & Horizontal & $5 / 30 / 86$ & 1.50 & 6.316 \\
\hline $\begin{array}{l}\text { Average } \\
\text { Average }\end{array}$ & $\begin{array}{l}1 \text { Measurem } \\
\text { tal Measur }\end{array}$ & $\begin{array}{l}42 \pm 0.2 \\
.125 \pm\end{array}$ & & \\
\hline
\end{tabular}

\subsubsection{Performance Observations}

Figure 4-2 is a summary of the vertical. TE measurements for approximately 1 yr of monitoring. Convergence into the drift is considered to be positive. Data points reflect the frequency of measurements.

Data are identified by stations and are provided for Stations A1-G (Figure 1-1). The added $V$ in the label signifies vertical data. All data, with tha exception of that collected from station $A 1$, show convergence 


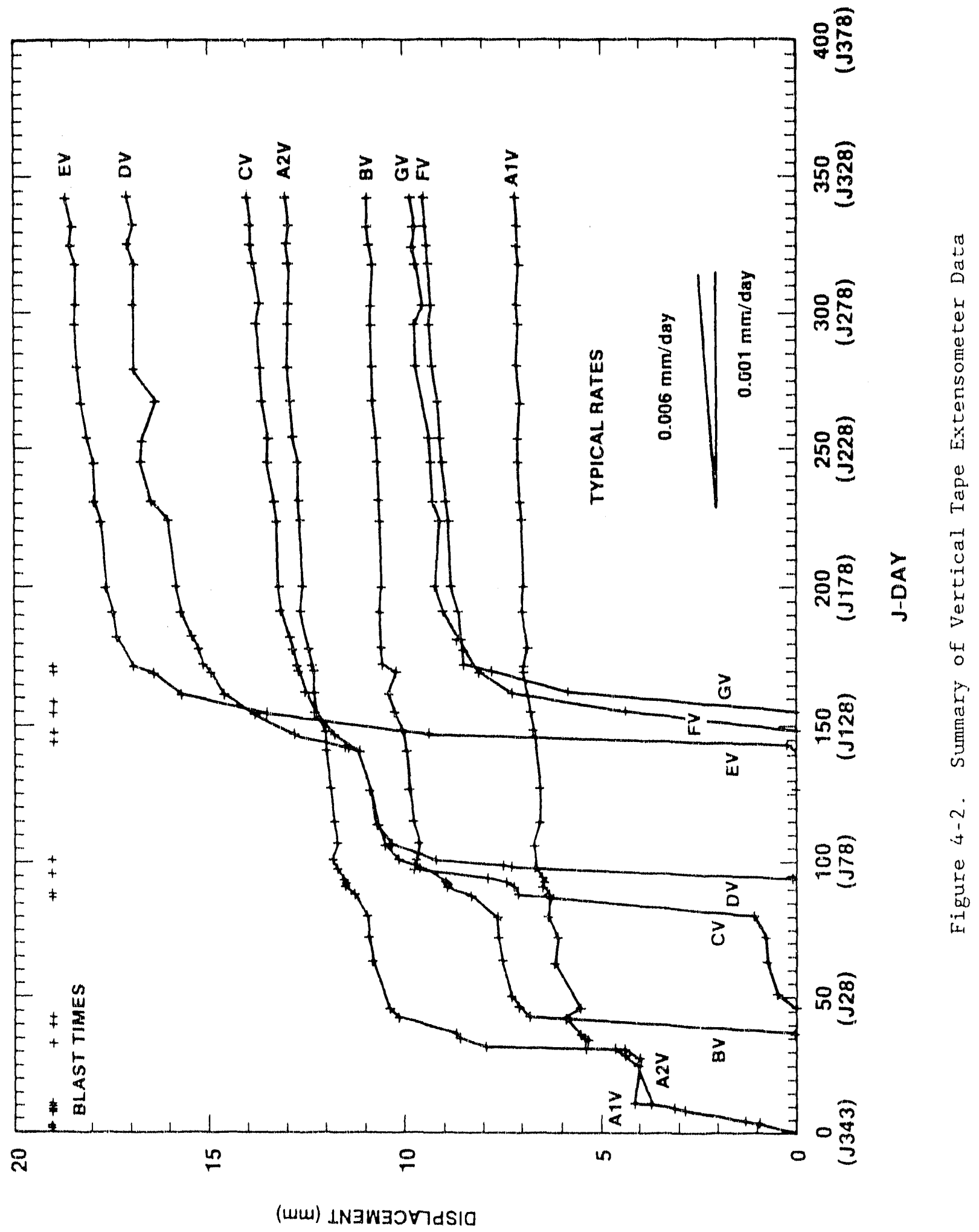


phenomena starting with the measurements taken next to an unexcavated face. Measurements at station A1 were Intefalized aftex some unknown convergence had occurred and were only used as a check for measurement techniques. The data from that station are not included in measurement discussions. Stations beyond $G$ were considered too close to the end of the drift for: meaningful. convergence data; hence, results are not provided in Figure 4.42.

Figure 4-3 is a summary of the horizontal TE measurements for the same time period. Horizontal data measurements started with Station $B$ and ended with Station $G$.

\subsubsection{Evaluation}

The TE measurement system proved to be a reliable masurement system. No anchors were lost or appeared to be threatened by the blasting. The TE proved to be a reliable instrument that was easy to handle.

\subsection{Borehole Injoction}

Water was injected at fixed intervals in six boreholes as a technique to evaluate changes in the rock mass resulting from the mining process. The water pressures and flow rates were measured and combined into a quantity called a hydraulic quotient (HQ) (Report $A$ )." This testing was a developmental effort in which $H Q$ measurements before and after the mining are used to determine changes in the rock mass caused by the excavation process. Pressure and flow rate measurements were essential for HQ determinations.

\subsubsection{Measurement Principles}

The use of flow measurements to estimate fracture properties in boreholes is an established technique in rock mechanics. In a recent: effort, Hodgkinson (1984) used flow measurcments, called permeability

*Zimerman et a1., 1.991 


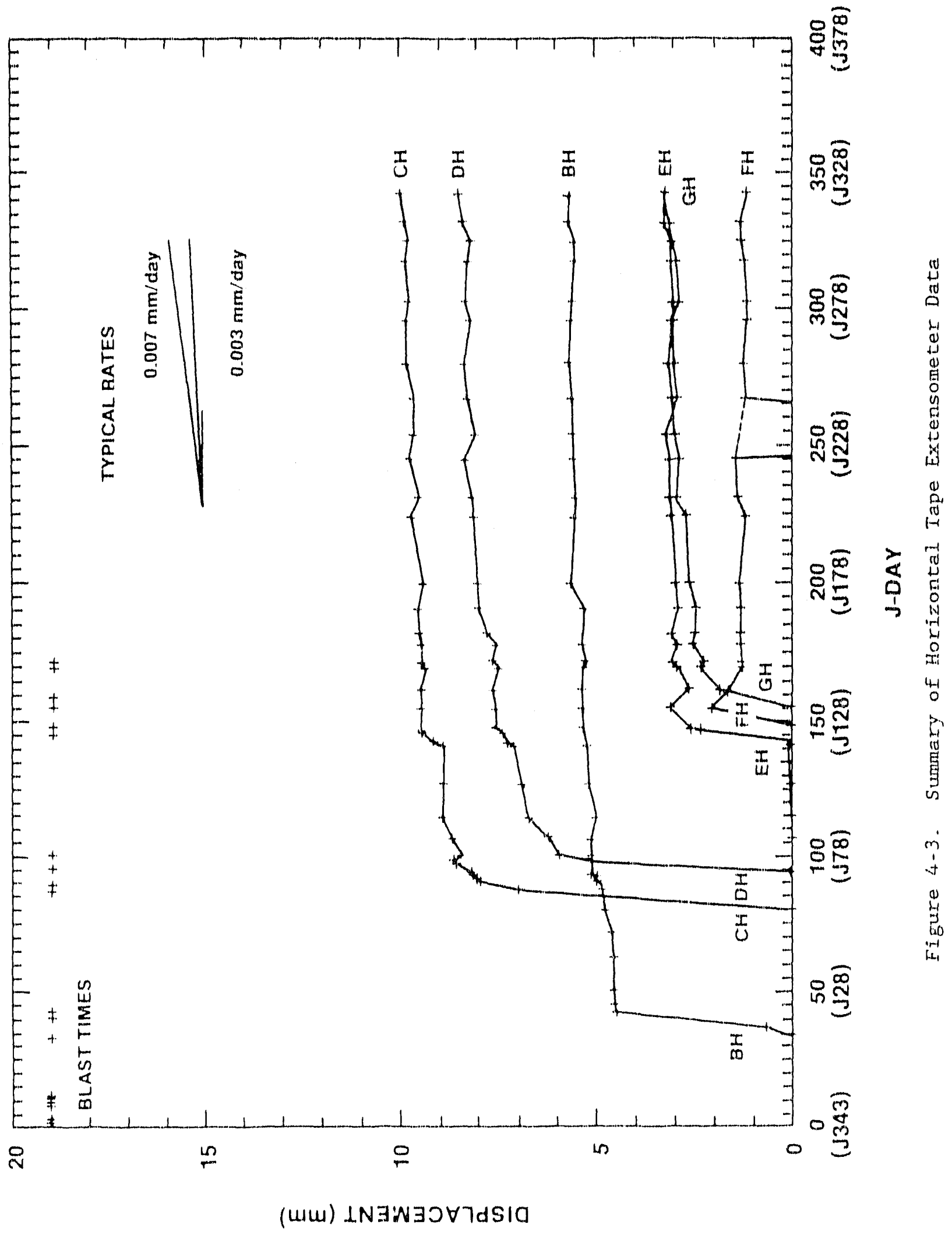




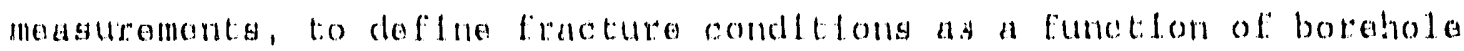
depth. He published resulteg for masumements of flow rate per und

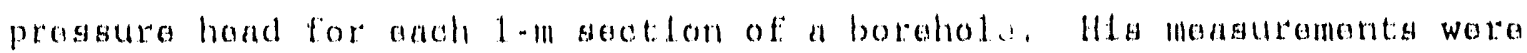
directed toward demonstrating the 1 taltations of us ling a continutum approach In descrlblng rock-mass flows, and he was primatly concenthed with demonstrating, fracture affects in rock masas.

'this developmental effort is an extenston of the Hodgkinson work. Flgure 4.4 shows a schemate 11 lustrating the movable masurement interval, whlch las the basto measurement approach used in thla study. 'Ihe Borehola Injection (B1) testing lnvolved taking the same type of moasurements bofore and after a dreft was mfned through a welded tuff. BI measurements were taken along the lengths of $s$ lx boreholes, which were arranged in patrs of: two at three stations, $B, D$, and F. Flgure 4.4 shows how two boreholes were orfented at one station. The holes orlginated In the 12-Drtft, and they were drllled before the minling of the Demonstation Drift.

The $H Q$ quantity ls taken as the ratio of $Q /\left(H_{0}, \gamma_{w}\right)$, whote $Q$ is the fllow rate $\left(\mathrm{m}^{3} / \mathrm{s}\right), \mathrm{H}_{\mathrm{o}}$ is the pressure head on the Interval ( $\mathrm{m}$ of $\mathrm{H}_{2} \mathrm{O}$ ), and $\gamma_{\mathrm{w}} \mathrm{t}_{\mathrm{s}}$ the undt welght per und volume of water $\left(\mathrm{N} / \mathrm{m}^{3}\right)$. Thls means that the HQ quantely has generle unlts of $\mathrm{m}^{5} / \mathrm{Ns}$. In the WTM testing the HQ is converted to undts of $\mathrm{m}^{3} / \mathrm{skPa}$ to be conslstent with the measurements that: were taken (Roport A). Thus, discusstons of lnstrumentation are focused on flow rate $\left(\mathrm{m}^{3} / \mathrm{s}\right)$ and pressure $(\mathrm{kPa})$.

\subsubsection{Measurement: Equlpment:}

Figure 4-5 shows a schenatio of the BI testing apparatus. The equlpment was assembled from components avallable $1 \mathrm{n}$ G-Tunnel and attached to a permeabl11ty cart, which had been fabrlcated for another SNL study. Some BI equipment was spectally fabricated for these measurements,

The key controls for the hydraulic system were valves regulating the flow race, Wator was pumped at a constant rate of $6 \times 10^{-4} \mathrm{~m}^{3} / \mathrm{s}$ (9.5 gal/min). The flow rate to the injection plping was regulated untel a clesfrec pressure at the infecton packer was achleved. The excess water 


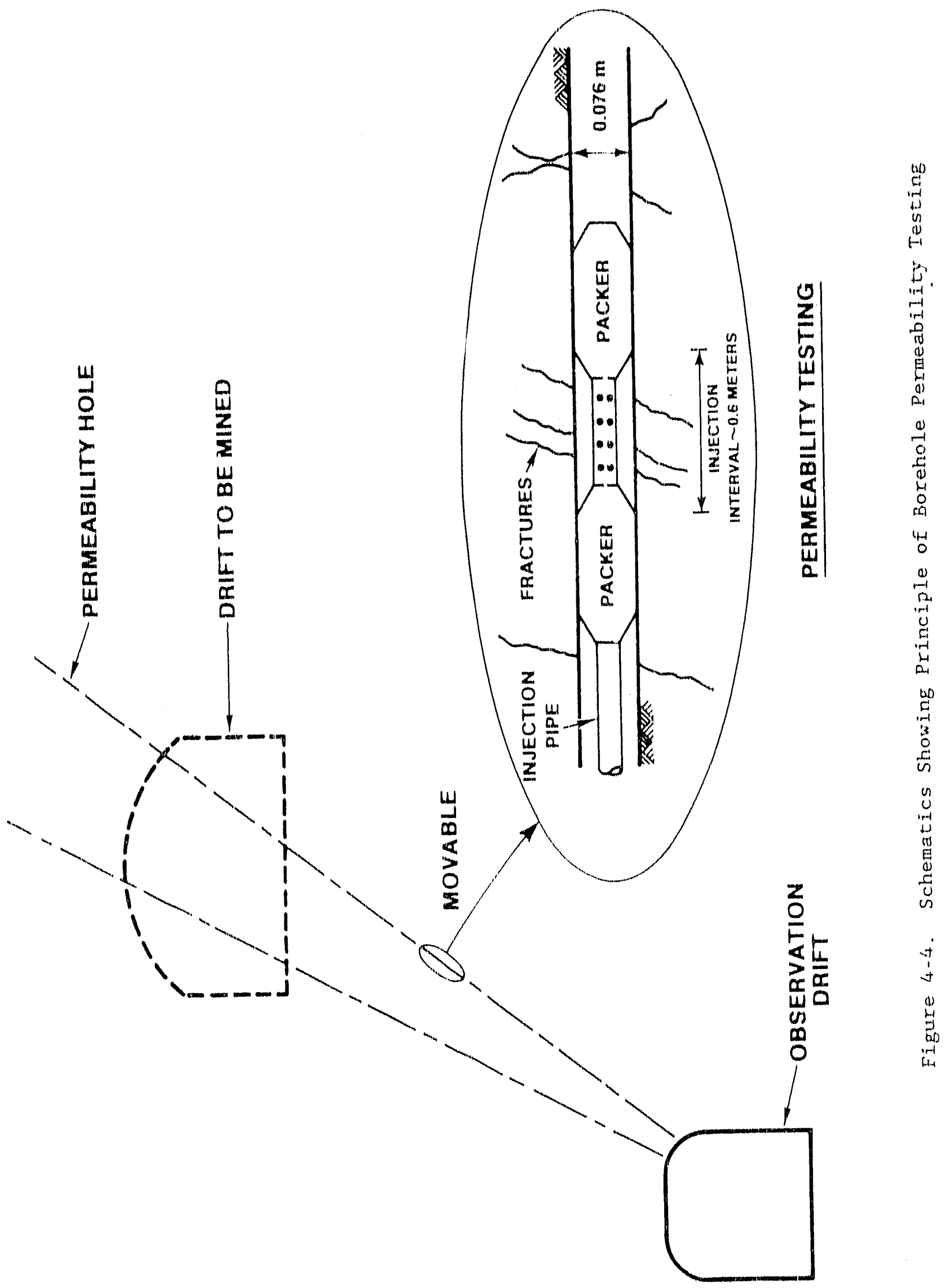




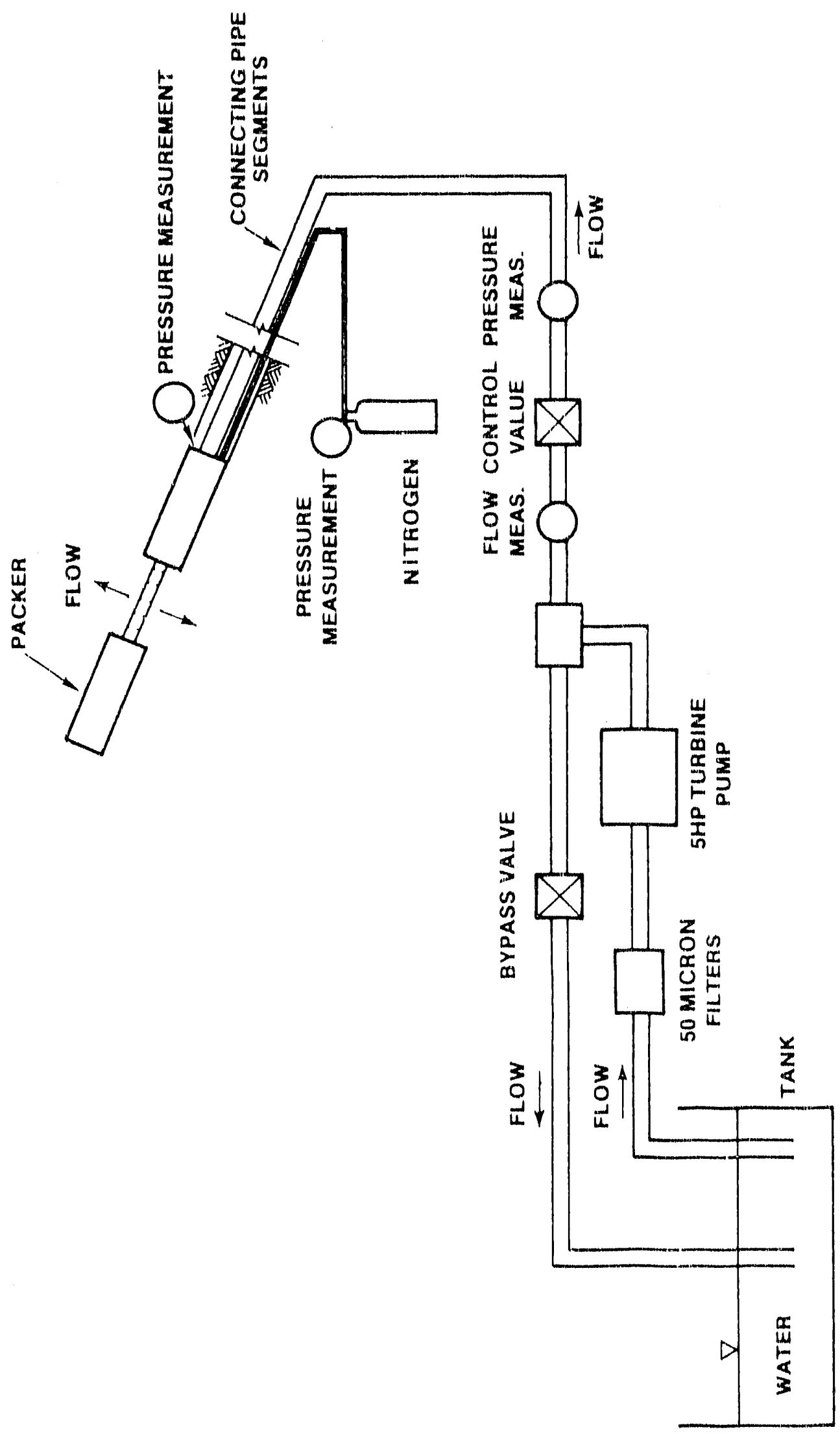


was returned to the tank through a bypass valve (Figure 4-5). When the desired pressure was achieved, the flow rate in the injection pipe was maintained at a steady-state condition and monitored for a specified time.

There were three key measurements in determining the HQ quantities: flow rate, pressure at the injection interval, and time. Additional pressure measurements were taken near the flowmeter, which was located on the permeability cart, to provide a better record of the hydraulic behavior of the flow system. Also, total flow volume was measured with the flowmeter to facilitate quality controls.

The flow rate and total flow volume were measured hy a flowmeter manufactured by Flow Technology (Model FT8). The flowmeter could measure flow rates up to $6 \times 10^{-4} \mathrm{~m}^{3} / \mathrm{s}(9.5 \mathrm{gal} / \mathrm{min})$. The lowest reading of the flowmeter was $6 \times 10^{-7} \mathrm{~m}^{3} / \mathrm{s}(0.01 \mathrm{gal} / \mathrm{min})$. The flow volume was read to the nearest $3.8 \times 10^{-4} . \mathrm{m}^{3}(0.1 \mathrm{gal})$.

The primary pressure gage, manufactured by Kulite (Mode1 XTM-1902006), had a range up to $1.4 \mathrm{MPa}$ (200 psi). Pressure could be read to the nearest $0.7 \mathrm{kPa}(0.1 \mathrm{psi})$.

Both the flowmeter and pressure gage were calibrated as part of the calibration program at the NTS. These gages were calibrated at nominal 6-mo intervals to maintain stability in the measurement systems. Also, part of the measurement procedure included checks to ensure that the measurement systems remained stable between calibrations. Time was measured with a commercially available stopwatch. Time was measured to the nearest second.

\subsubsection{Performance Observations}

A total of $440 \mathrm{HQ}$ determinations were made (Report $\mathrm{B}^{*}$ ). In many cases, the measurements were repeated by the operator if the results were questionable. In Report B, 36 of the 440 measurements were considered to

*Zimmerman et a1., 1990 
be suspect and were deleted from further analyses. Reasons for the deletions, which included statistical and error analyses, are provided in the report. Five sets of readings were taken at each measurement position in the boreholes and a mean and standard deviation was established for each HQ determination. As part of the overall measurement considerations, rock mass changes between pre- and postmining measurements should be outside the statistical variance of the measurements.

Figures 4-6 through 4-11 show HQ profiles for pre-and postmining situations for the six boreholes. The data shown are the average of all of the nonsuspect measurements for a particular depth. The range of \pm 1 standard deviation is shown for the included data for each plotted point so that statistical inferences can be applied to the measurement trends. The figures also show the ranges of the excavated region and the limits for the welded and nonwelded tuffs. The region between the welded and nonwelded tuffs is not identifled because it is difficult to characterize the vitrophyre and the rubble zone. Many of the differences occurred in the transition zone between the nonwelded and welded tuff units, such as in Borehole B3, and were most likely influenced by the rubble zone. These were not the changes that were of interest. The primary changes of interest were in the welded tuff above the excavated region.

An important consideration was whether the flow measurements were sensitive enough to detect changes in the rock mass. The figures show that, in most cases, there were distinct differences between pre- and postmining measurements. The observed changes were greater than the errors of measurements.

A final comment on the data presented in Figures 4-6 through 4-11 deals with measurement limitations. Because of the configuration of the packer assembly, the center of the measurement interval could not be located closer to the drift surface than a distance of $0.8 \mathrm{~m}$. This means that fracture influences within $0.4 \mathrm{~m}$ ( $1 / 2$ the measurement interval) were not included in the measurements. The actual measurement could be at an 


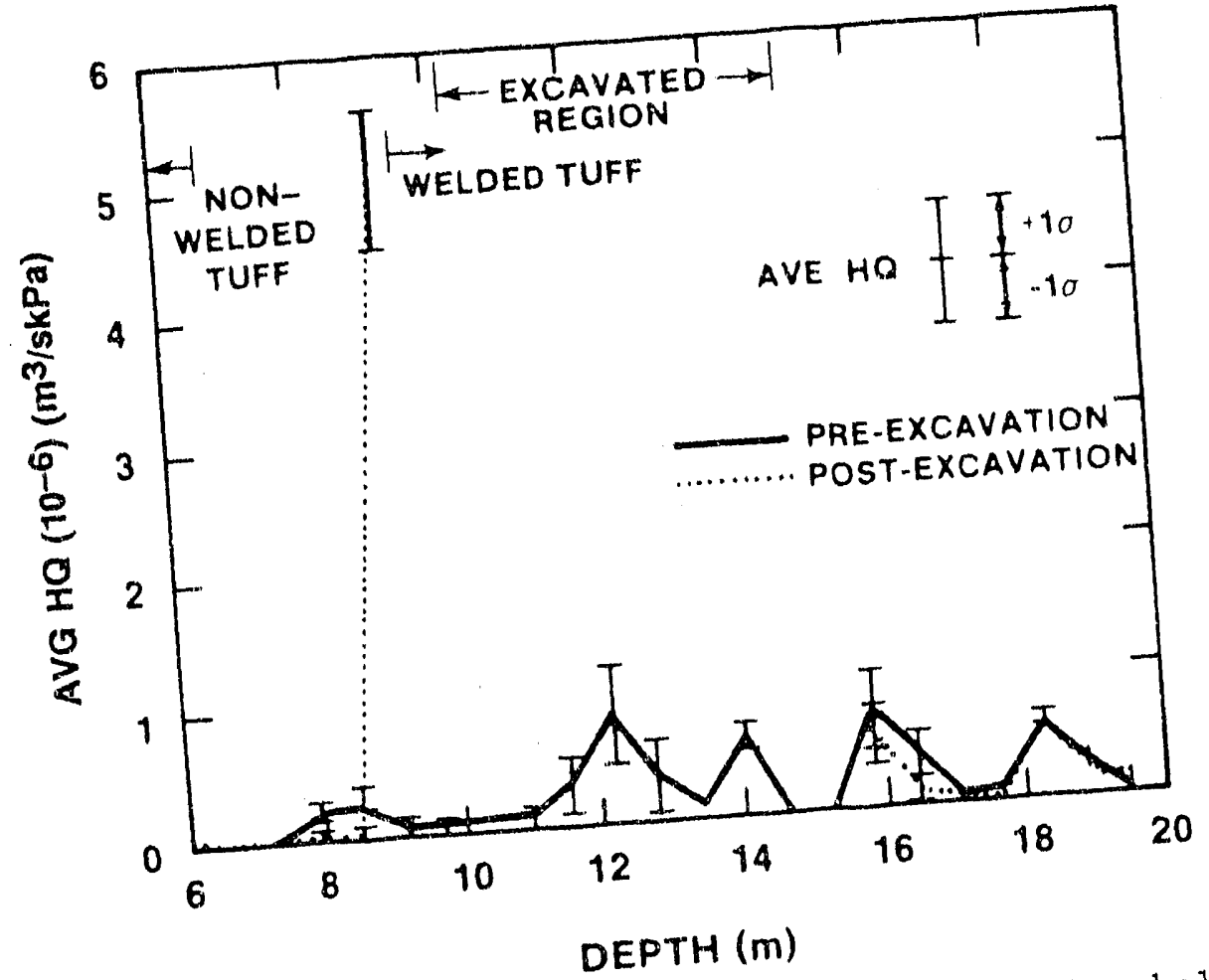

Figure 4-6. Pre- and Postmining HQ Profiles for Borehole B2

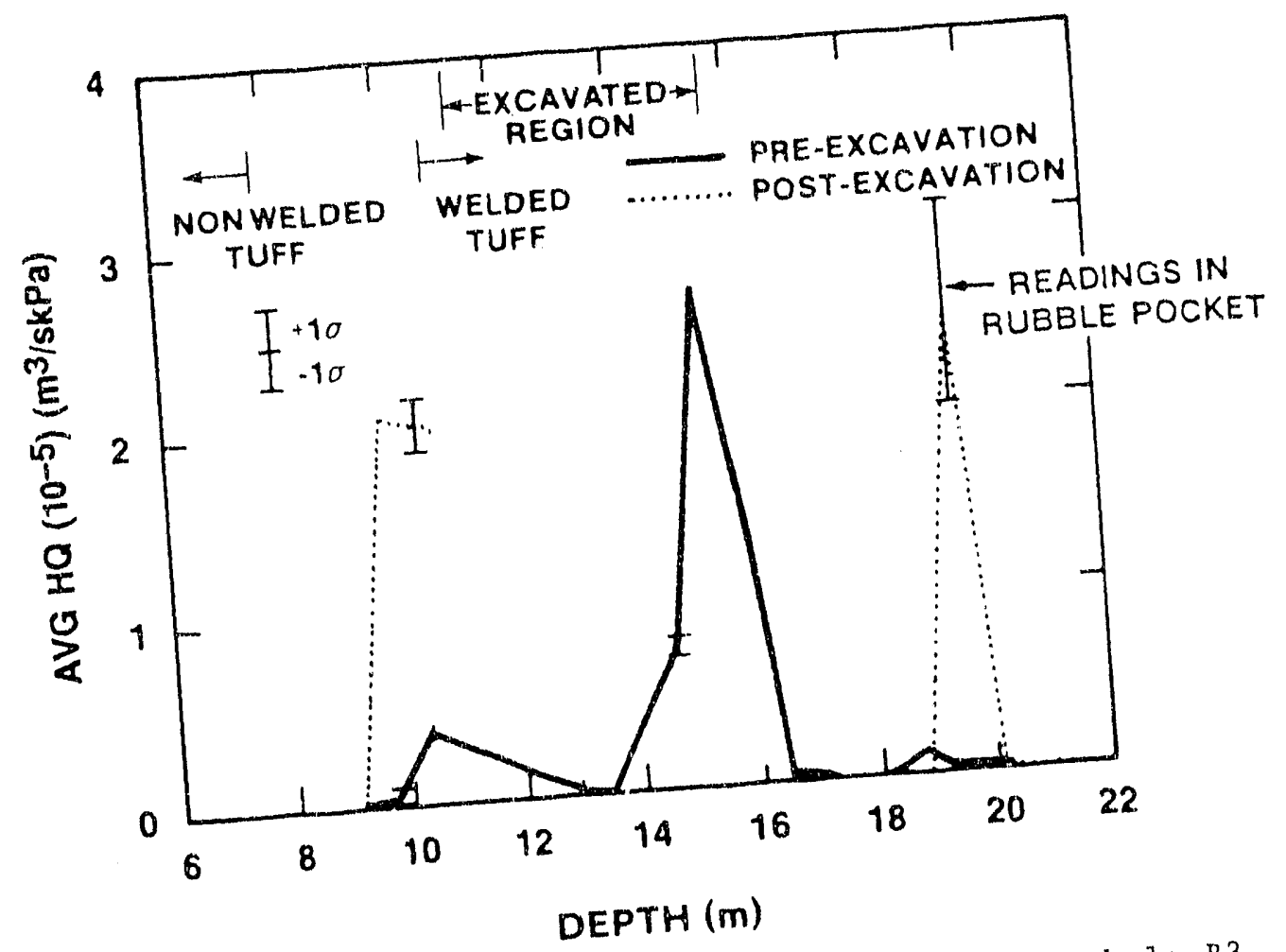

Figure 4-7. Pre- and Postmining HQ Profiles for Borehole B3 


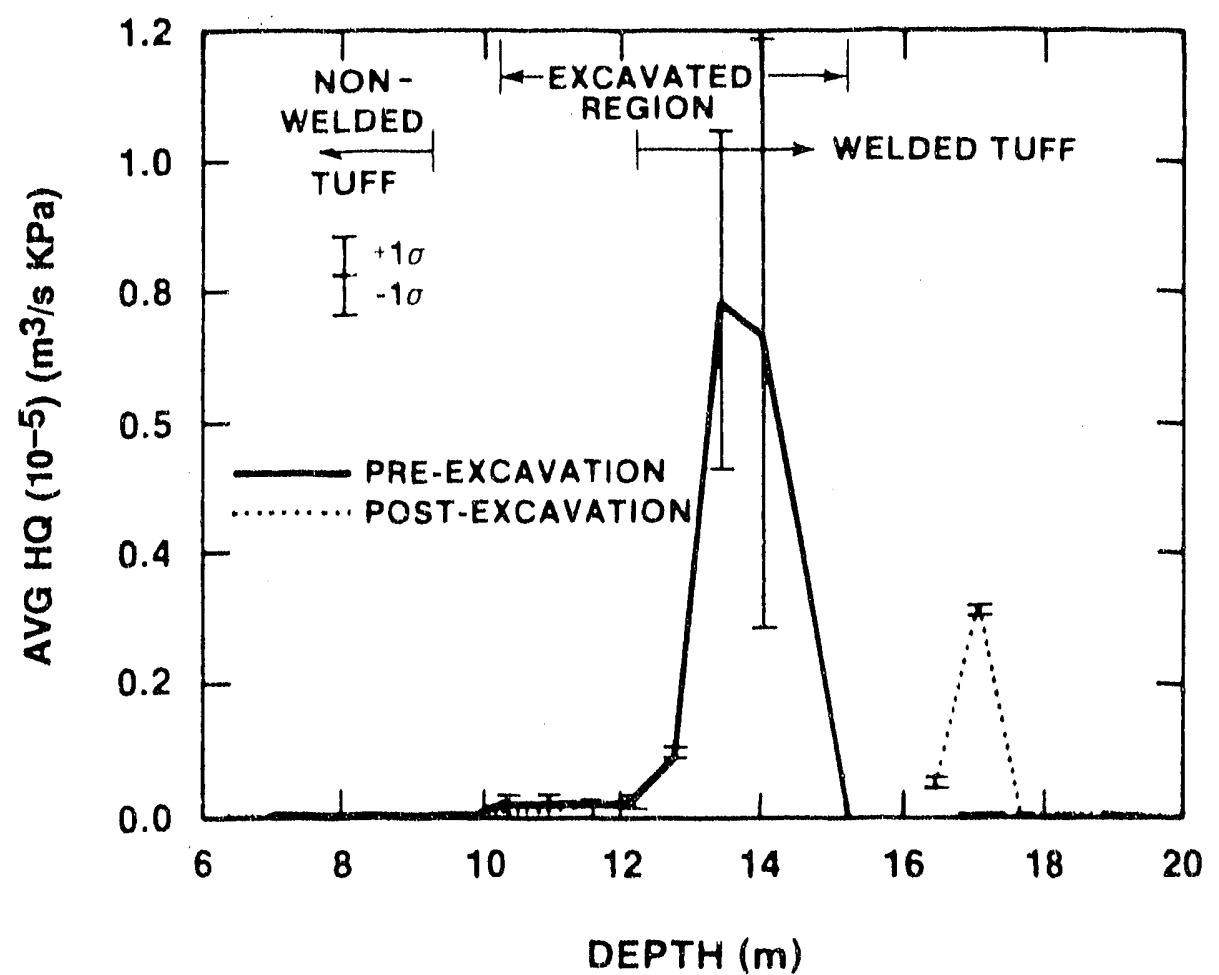

Figure 4-8. Pre- and Postmining HQ Profiles for Borehole D2

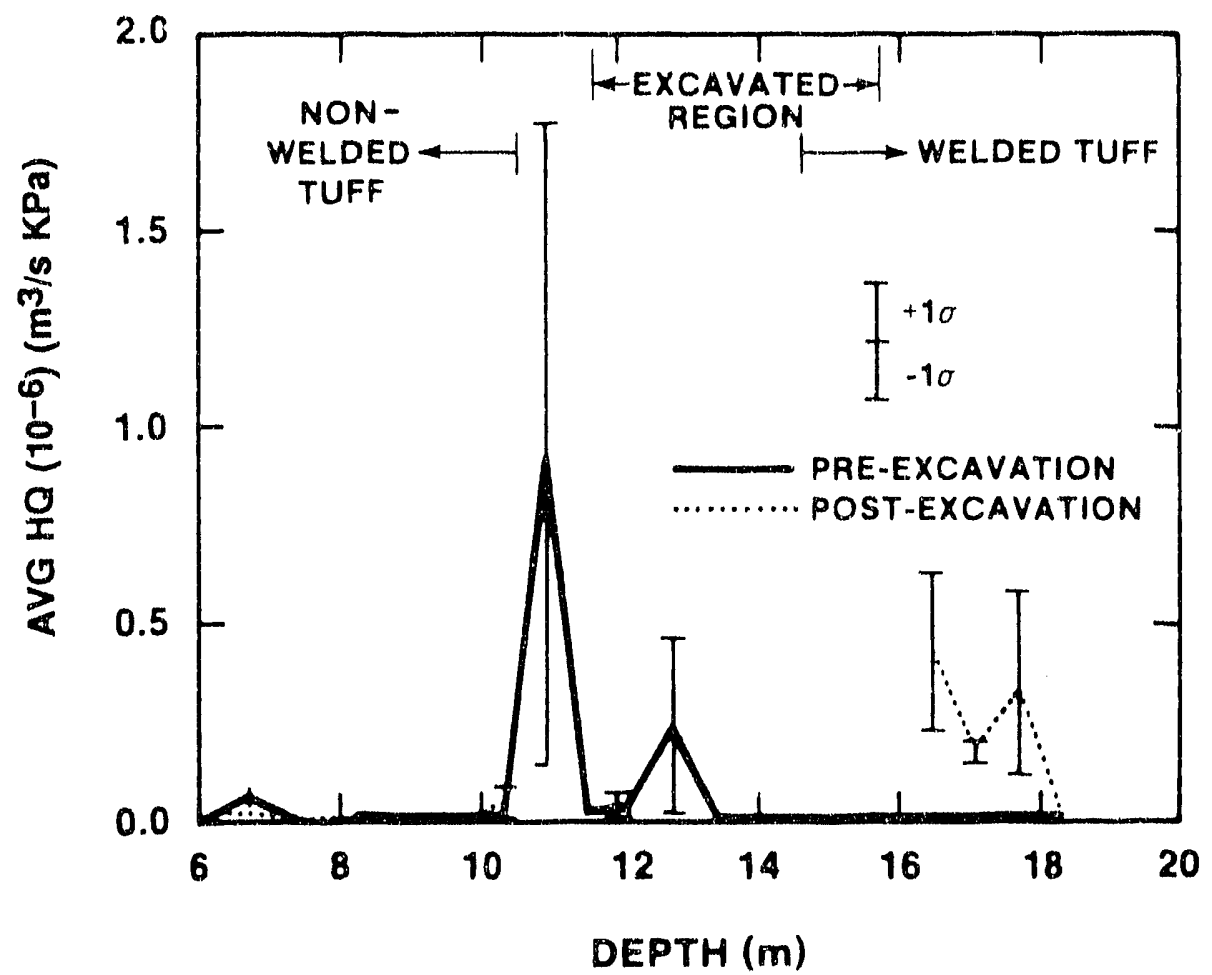

Figure 4-9. Pre- and Postmining HQ Profiles for Borehole D3 


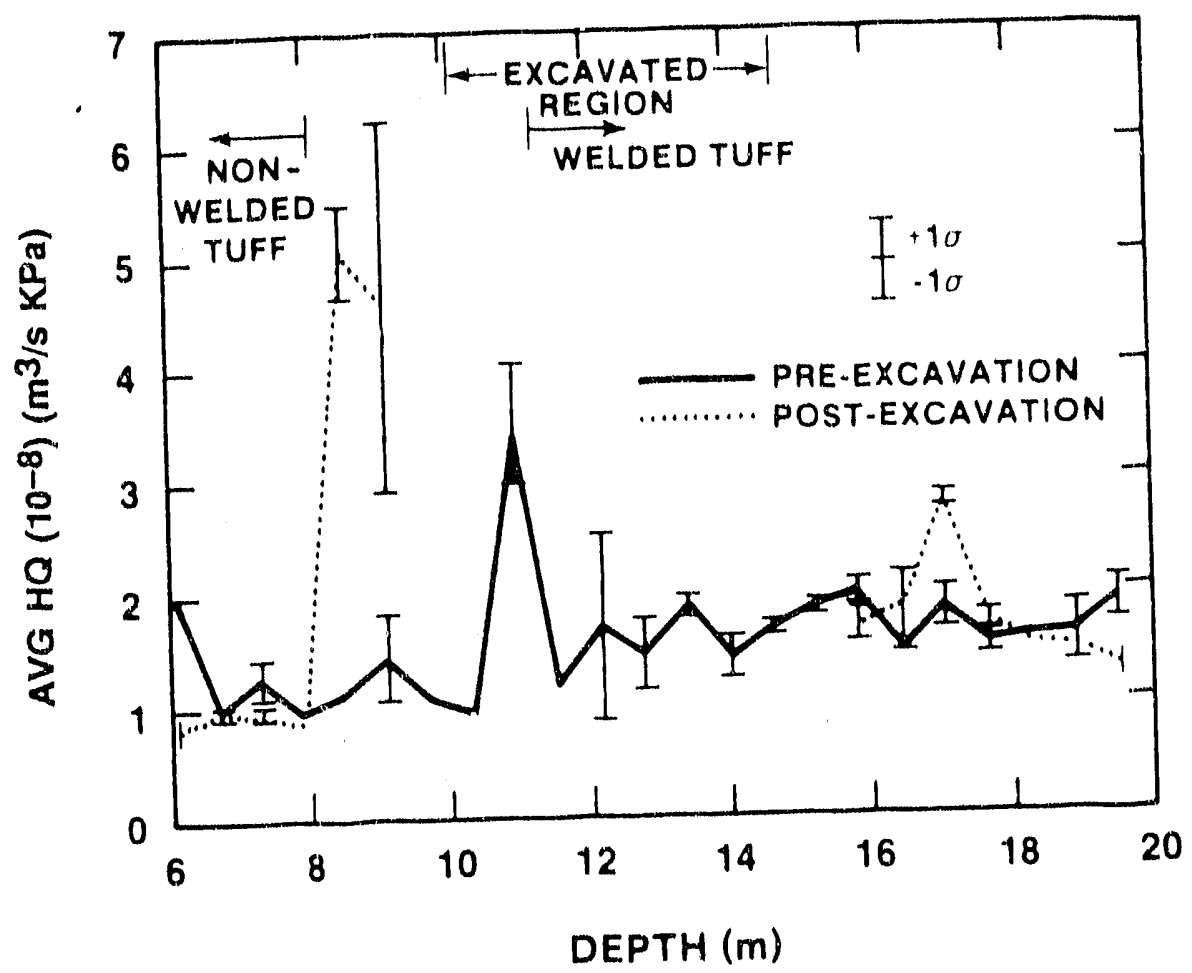

Figure 4-10. Pre- and Postmining HQ Profiles for Borehole F2

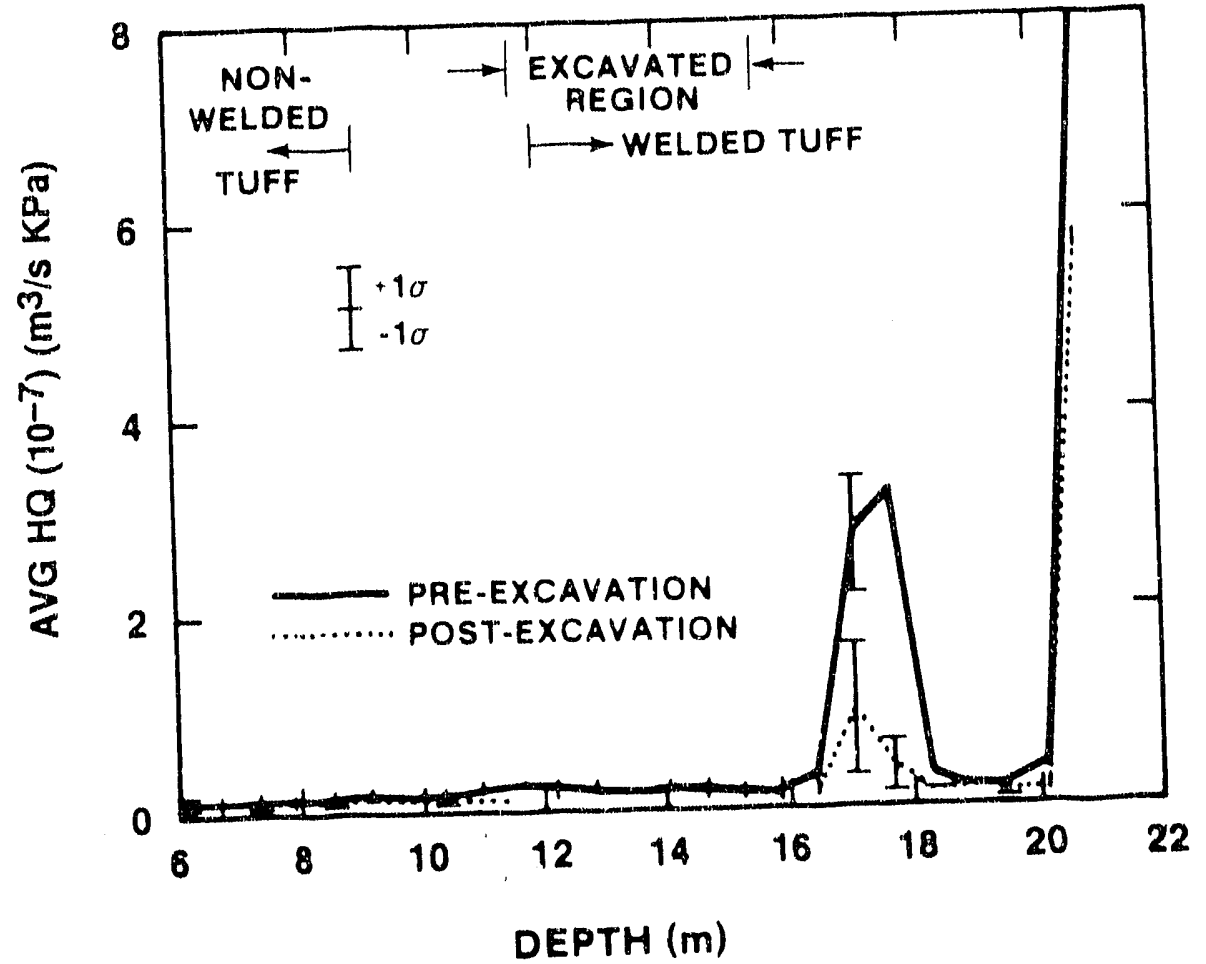

Figure 4-11. Pre- and Postmining HQ Profiles for Borehole F3 
even greater distance because the inftial measurement intervals were referenced to the collars in the 12 -Drift, and a normal measurement location could be deeper into the rock.

A factor in the data collection was the operability of the Vishay. Strain Indicators (Model P-3500) that were used to read pressures. The units are normally used with strain-gage type measurements and were stored underground between measurements. Moisture from the high relative humidity in the tunnel collected in the units, On occasion, the digital displays would not be readable or the unit could not be balanced, and the operator would have to take the unit outside to dry out before using. Once the unit was dry, it appeared to operate properly.

\subsubsection{Evaluation}

Error evaluations in Report B provided an analysis of measurement and operational errors for the permeability testing. A rational approach was used to cull suspect data so that the resulting data would be meaningful. The analyses showed that most of the errors occurred at the low flow rates, where measurements were not generally applicable to welded tuff evaluations. Figures 4-6 through 4-1.1 show that there were distinct differences between pre - and postmining data. These differences were most likely caused by changes in the rock mass. The statistical analyses support the premise that the differences were caused by the rock behavior.

Major problems were insensitivity of the measurement equipment at low flow rates and variations in flow rates during testing (Report B). The equipment problem can be resolved easily through procurement specifications. The problem of evaluating variations in flow rates is a judgement that the operator needs to make. The operator had the responsibility to evaluate the data at the time of collection and repeat any measurement series that were suspect in his mind. A considerable amount of data was collected, some later found to be unnecessary. For future efforts it is recommended that the operator be better trained in equipment operation and data analyses. Emphasis in the latter could be based on the error analyses discussed in Report $B$. 
In summary, the BI method appears technically feastble for consideration for future testing efforts in the ES. The measurement components functioned satisfactorily. This was a developmental effort and, in evaluation, there were an unusually high number of measurements taken because of a lack of criterla for identifying suspect measurements. Better operator training should improve this.

\subsection{Borehole Deflectometer}

A borehole deflectometer ( $B D$ ) was used to attempt to determine changes in alignments of boreholes drilled around the excavated region. The changes were to be related to mining effects. This was a third developmental effort because measurements of this type had not previously been conducted in a hard rock. The method was selected to determine whether the BD could be used as a supplement to the MPBXs, which are not as sensitive to detecting rockmass changes perpendicular to the borehole (Heuze et. al., 1981).

\subsubsection{Measurement Principle}

Figure 4-12, a schematic illustrating the basic principle involved in these measurements, shows a borehole in the pre-and postmined position. After mining, the borehole axis is expected to move toward the excavated region and deform slightly. Ideally, the deformed alignment of the borehole axis can be obtained by making the same type of measurements before and after the mining process. The borehole deflections are smal1, and measurements are possible because of the availability of an extremely sensitive $B D$, which can have an inherent sensitivity of 1.0 arc-second $(1 / 1,296,000)$.

The alignment of a borehole can be measured with a $B D$ by taking angle change measurements as a function of the borehole length. This is called a borehole traverse, and the plot of the resulting angle change measurements is called a borehole angle change protile. A proflle was established in these efforts by measuring angle changes at intervals of $0.76 \mathrm{~m}(2.5 \mathrm{ft})$. At each interval, an analog reading, representing an angle between two 


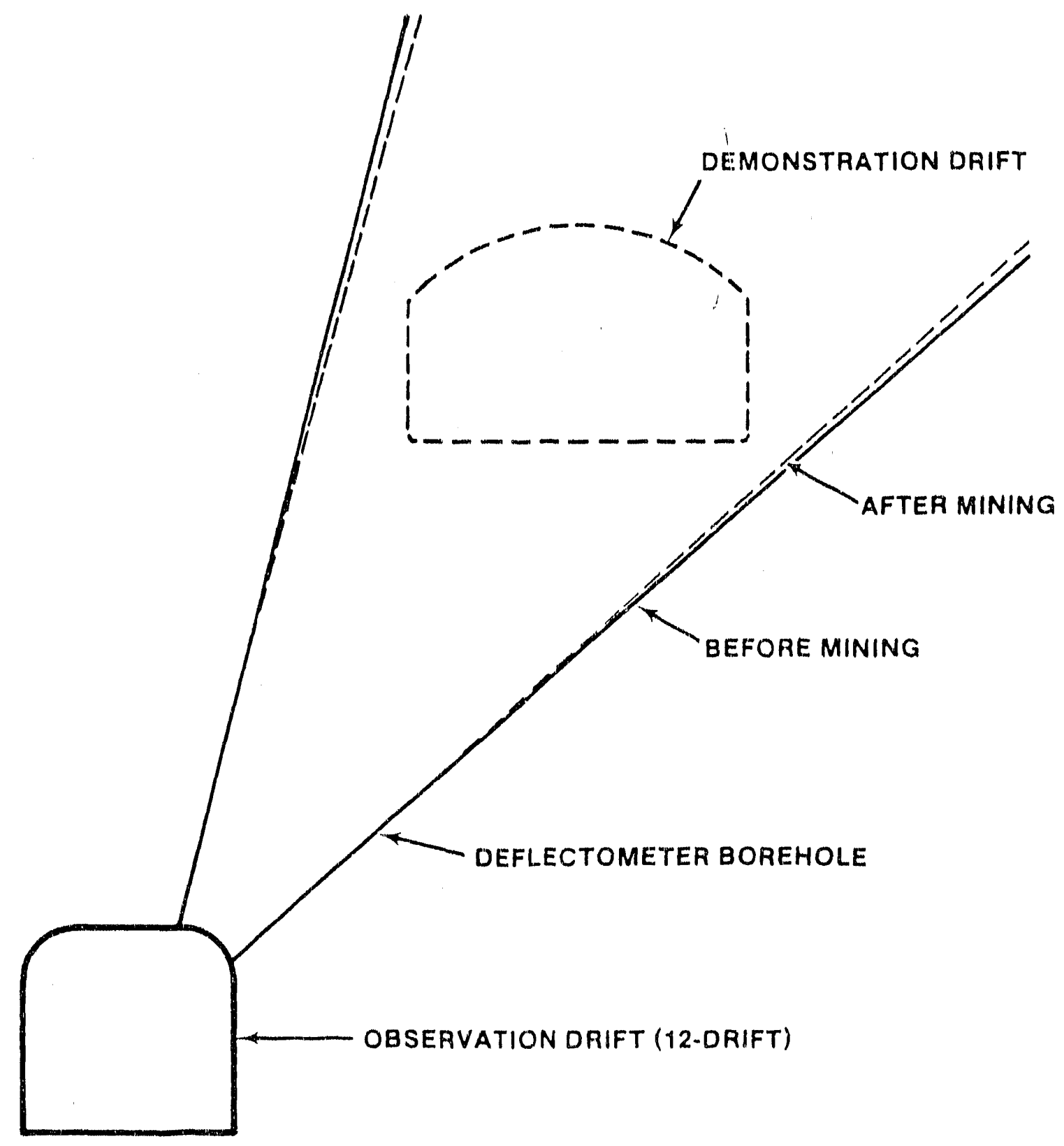

Figure 4-12, Schematic Showing Mining-Related Deflectometer Measurement Concept 
arms of an articulated deflectometer, was displayed in digital form on a digltal display meter (DDM) located outside the borehole. The digital readings were manually recorded and later converted to degrees using a conversion factar.

Figure 4-13 shows a schematic of the BD and the angle change that can be measured with $1 t$. Also shown is a representation of the tangential deflection. The tangential deflection is a useful extension of the angle change measurements because it translates angle measurements into linear measurements.

\subsubsection{Measurement: Equipment}

The BD was manufactured by Stnco/Terrametrics, Mode1 PBD/TCD (Table 2-2). The $B D$ consists of two straight fixed-length segments linked together with a strain-gaged flexible connection. The BD was manufactured so that the three permanently positioned wheels were the primary reference set for traverses, and a set of three spring-mounted wheels was used to keep the BD aligned In a grooved PVC casing. During a traverse, the flexible connection transmits a continuous signal that is the analog of the angle between the two segments.

A specially grooved PVC casing was grouted into each of the boreholes to ensure good coupling with the rock. The casing, which is $69.5 \mathrm{~mm}$ in diameter, was purchased in 3.0 -m lengths and glued together during installation. The casing was fabricated so that the $B D$ could be orfented in two orthogonal positions. Specifically, the casing has four small. grooves $[1.65 \times 5.1 \mathrm{~mm}(0.065 \times 0.2 \mathrm{fn})$.$] cut in the inside wall of the$ casing at four quadrant points.

\subsubsection{Performance Observations}

Fifteen borehole traverses were conducted before, during, and after the mining (Report B). Table 4-2 provides information about the 15 borehole profiles that were recorded (Report $B$ ). The information in the first two columns is descriptive. Quantities in Columns 3 and 4 provide 


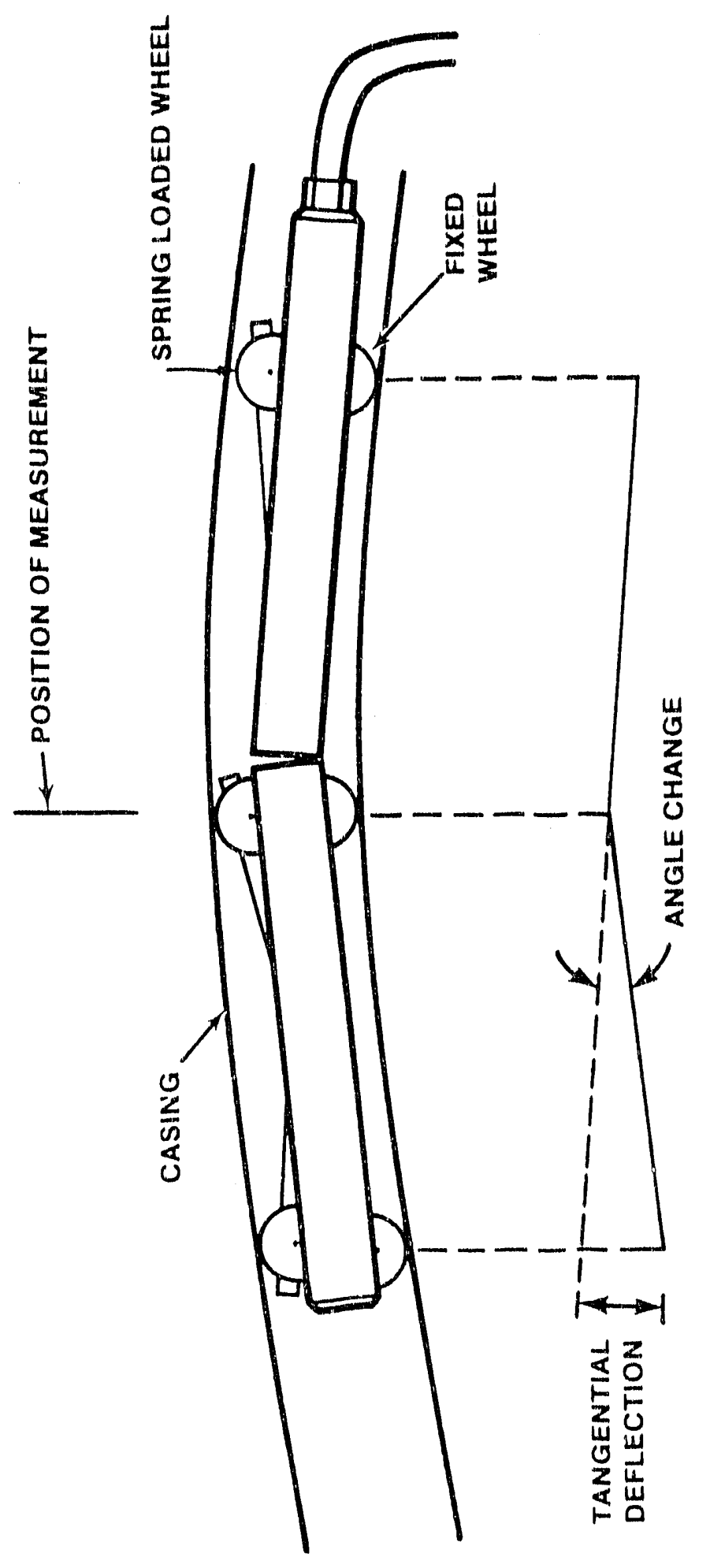

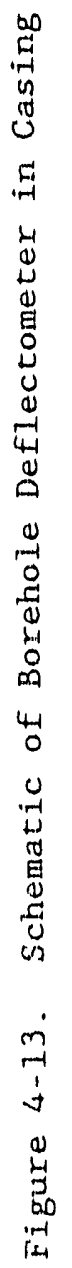


T'able 4-2. Sumnary of Computed Values for BD Exror Anelyses

\begin{tabular}{|c|c|c|c|}
\hline Borehole & Date & $\begin{array}{l}\text { SUM RI } \\
\text { ASC }\end{array}$ & $\begin{array}{l}\text { SUM RI } \\
\text { Desac }\end{array}$ \\
\hline$B 1$ & $\begin{array}{l}8511.01 \\
860.29 \\
860<17 \\
860602\end{array}$ & $\begin{array}{r}-27.4 \\
-100.9 \\
-130.4 \\
-148.5\end{array}$ & $\begin{array}{r}-21.2 \\
-104.5 \\
-134.6 \\
-162.2\end{array}$ \\
\hline$B 4$ & $\begin{array}{l}851101 \\
860129 \\
860417 \\
860602\end{array}$ & $\begin{array}{r}25.0 \\
.65 .9 \\
-75.4 \\
-70.0\end{array}$ & $\begin{array}{r}35.6 \\
-30.0 \\
-71.5 \\
-70.3\end{array}$ \\
\hline F1 & $\begin{array}{l}851101 \\
860417 \\
860602\end{array}$ & $\begin{array}{l}-1.41,6 \\
-221,7 \\
-259,0\end{array}$ & $\begin{array}{l}-141.4 \\
-223.4 \\
-252.0\end{array}$ \\
\hline $\mathrm{F} 4$ & $\begin{array}{l}851024 \\
86011.0 \\
860417 \\
860602\end{array}$ & $\begin{array}{r}10.4 \\
-55.3 \\
-90.9 \\
-102.4\end{array}$ & $\begin{array}{r}4.6 \\
-57.1 \\
-101.4 \\
-108.2\end{array}$ \\
\hline
\end{tabular}

a summary of the sum of angle changes for the ascending and descending traverses. If the quantities in these columns are the same, then there were no cumulative errors that affected the traverses and the traverse repeatabilities are considered excellent. Differences indicate cumulative angle measurement errors that can lead to a rather large estimated error (Report B).

Time-dependent initial measurement changes were observed. This can be seen through a listing of a sample of the readings. Table $4-3$ lists the digital readings for the first two intervals for each of the traverses. The first: two intervals were selected because they should be the least sensitive to location errors in the borehole. These data are useful for error analyses. The table shows that there were time-dependent changes of the values. The time-dependent drift as a function of date of testing is most noticeable for the 0.76 -m intervals as each one showed a negative change with time. This drift is symptomatic of zero shift, a common occurrence in working with strain gages that are placed in warm, molst environments. 
'Table 4-3. BD Readings at Flest: Two Intervals

\begin{tabular}{|c|c|c|c|c|c|}
\hline \multirow[b]{3}{*}{ Borchole } & \multirow[b]{3}{*}{ Date } & \multicolumn{4}{|c|}{ Digtal Readings } \\
\hline & & \multicolumn{2}{|c|}{ Ascendfing } & \multicolumn{2}{|c|}{ Desuend Ing } \\
\hline & & 0.00 & 0.76 (in) & 0,00 & $0.76 \mathrm{~m} 2$ \\
\hline \multirow[t]{4}{*}{ B1. } & 851.01 & -25.49 & 2.40 & -2.4 .95 & 2,51 \\
\hline & 860129 & -28.79 & .0 .01 & $-28,90$ & 0.00 \\
\hline & 860417 & $-30,23$ & .1 .15 & .29 .25 & -1.55 \\
\hline & 860602 & $.31,90$ & $-2,67$ & .31 .55 & -3.26 \\
\hline \multirow[t]{4}{*}{$B 4$} & 851.101 & 45.78 & -2.98 & 45.96 & -2.51 \\
\hline & 860129 & 36.25 & -3.32 & 44.03 & -6.10 \\
\hline & 860417 & 42.63 & .7 .89 & 42.34 & -6.96 \\
\hline & 860602 & 43.52 & -8.00 & 41,92 & -7.35 \\
\hline \multirow[t]{3}{*}{ F1 } & 8511.01 & -69.06 & $-31,11$ & $-6,7.73$ & $-30,91$ \\
\hline & 8604.17 & .70 .59 & -36.04 & -70.90 & -36.42 \\
\hline & 860602 & -71.92 & -37.55 & -71.71 & $-38,18$ \\
\hline \multirow[t]{4}{*}{ F4 } & 851.02 .4 & -1.6 .08 & 10.71 & -16.76 & 10.22 \\
\hline & 860110 & -22.70 & 7.62 & -23.31 & 7.19 \\
\hline & 86041.7 & -25.58 & 5.64 & $-26,11$ & 4.48 \\
\hline & 860602 & -25.82 & 4.68 & -26.20 & 4.30 \\
\hline
\end{tabular}

The reading of 36.25 for $34-860129$ (ascending) 1s an apparent anomaly In Table 4-3. The difference between that and the corresponding descending value was the largest measured. All other ascending and descending reading trends were simflar to the values represented by the other data in the table!.

Table 4-3 also shows that the first readings were relatively high for all of the holes. The larger values could have been caused by (1) vartations in the hole alignment at the collar, (2) vartations in the position of the PVC tube in the hole, and (3) the fact that the end of the PVC tube was not supported by the grout. No single cause was identffied.

Performance of the BI) can be best 11lustrated with an analysis of the data. For a setting of the BD in a borehole the angle of the two segments can be determined from the following (Report $B$ ):

$$
A_{1}=C_{1} \times R_{1}
$$


where

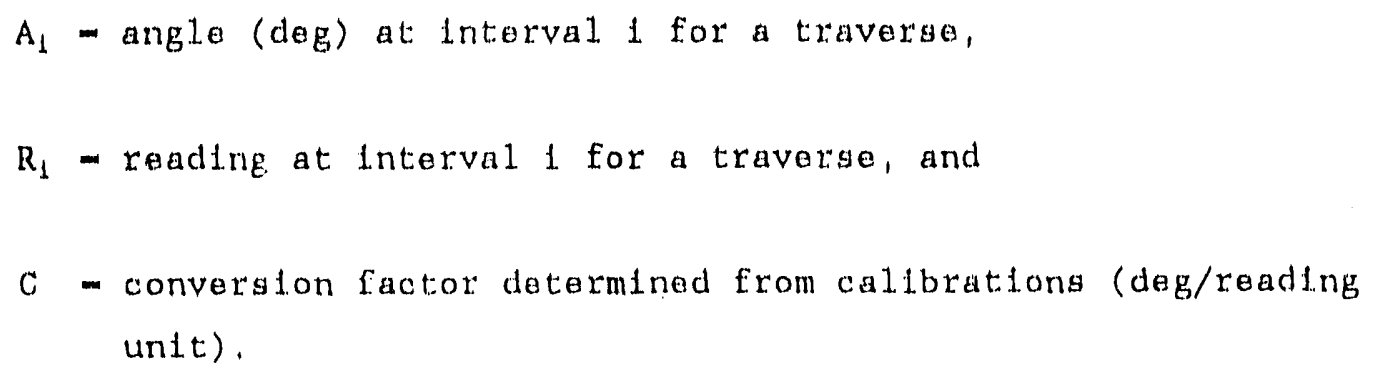

Angles calculated with Equation 4-1 can be Influenced by timedependent signal drift in the BD sensor or digltal readout box, Long-term signal drift problems shown in Table $4-3$ can be reduced by considering, angle changes as a function of borehole length. The assumption is that short-term signal drift, which might occur in a chay of testing, is negligible. An angle change relationship is expressed as (Report B);

$$
D A_{1}=C \times\left[R_{1}-R_{1-1}\right]
$$

where

$\mathrm{DA}_{1}$ walle change (deg) at interval position 1 for a traverse, and $\mathrm{DA}_{1} \quad 0$ and $2<1<23$.

Error analyses were performed on the data (Report B). The analyses showed that there was an estimated angle change error of at least $0.034^{\circ}$ for each measurement. The two major sources of error were temporal. instablitty of the conversion factor (C) and the repeatabllity of measurements in a single traverse. The temporal instability of the conversion factor was discovered in successlve callbration checks performed at SAIC.

Flgures 4-1.4 through 4-17 show average angle changes plotted as discrete quantities for intervals defining the traverse lengths. Maximum error estimates are shown in Figures 4-14 through 4-17 to assist in the analyses. Plots are from Report $B$. The intention of the measurements was 


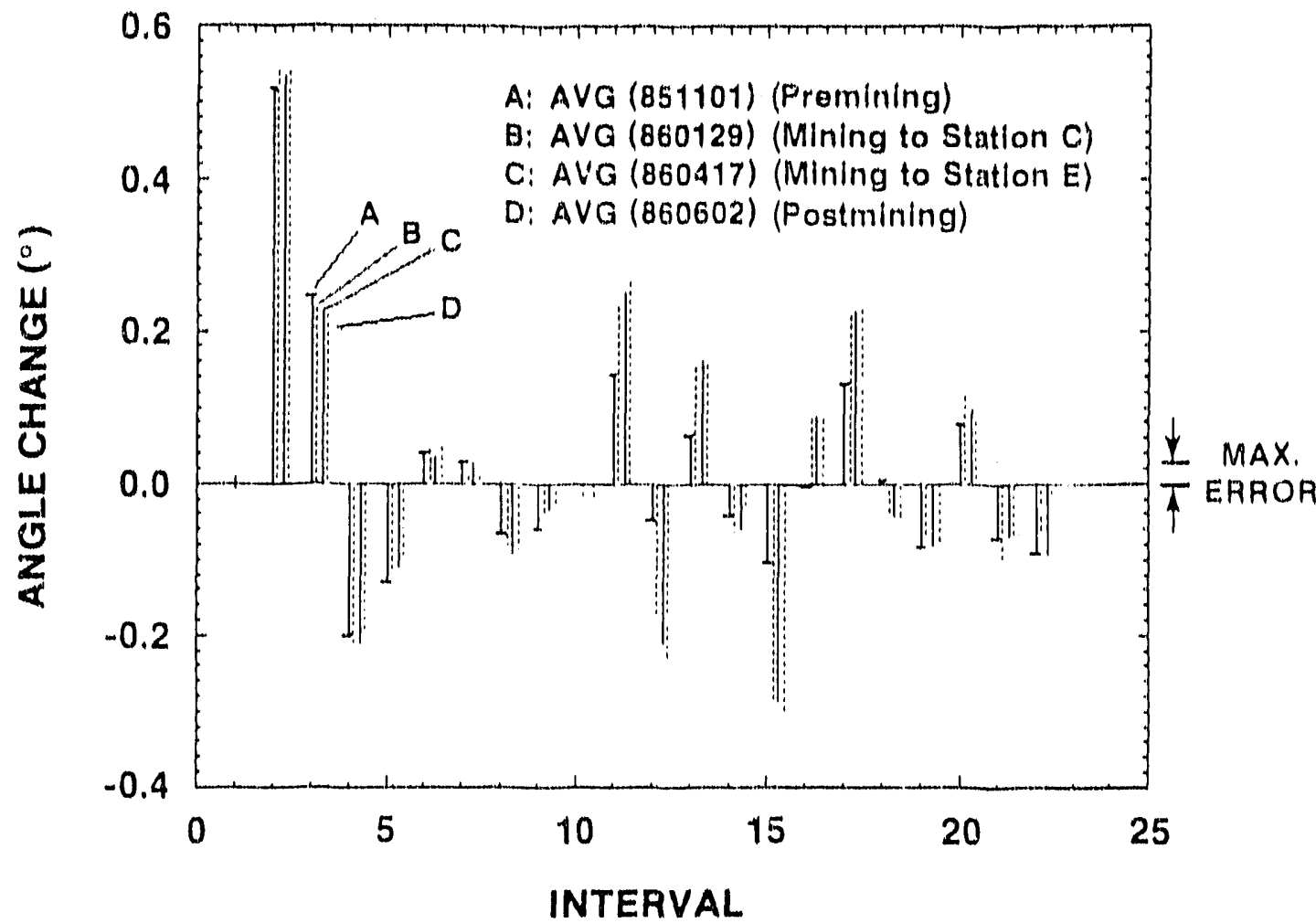

Figure 4-14. Angle Change Profiles for Borehole B1

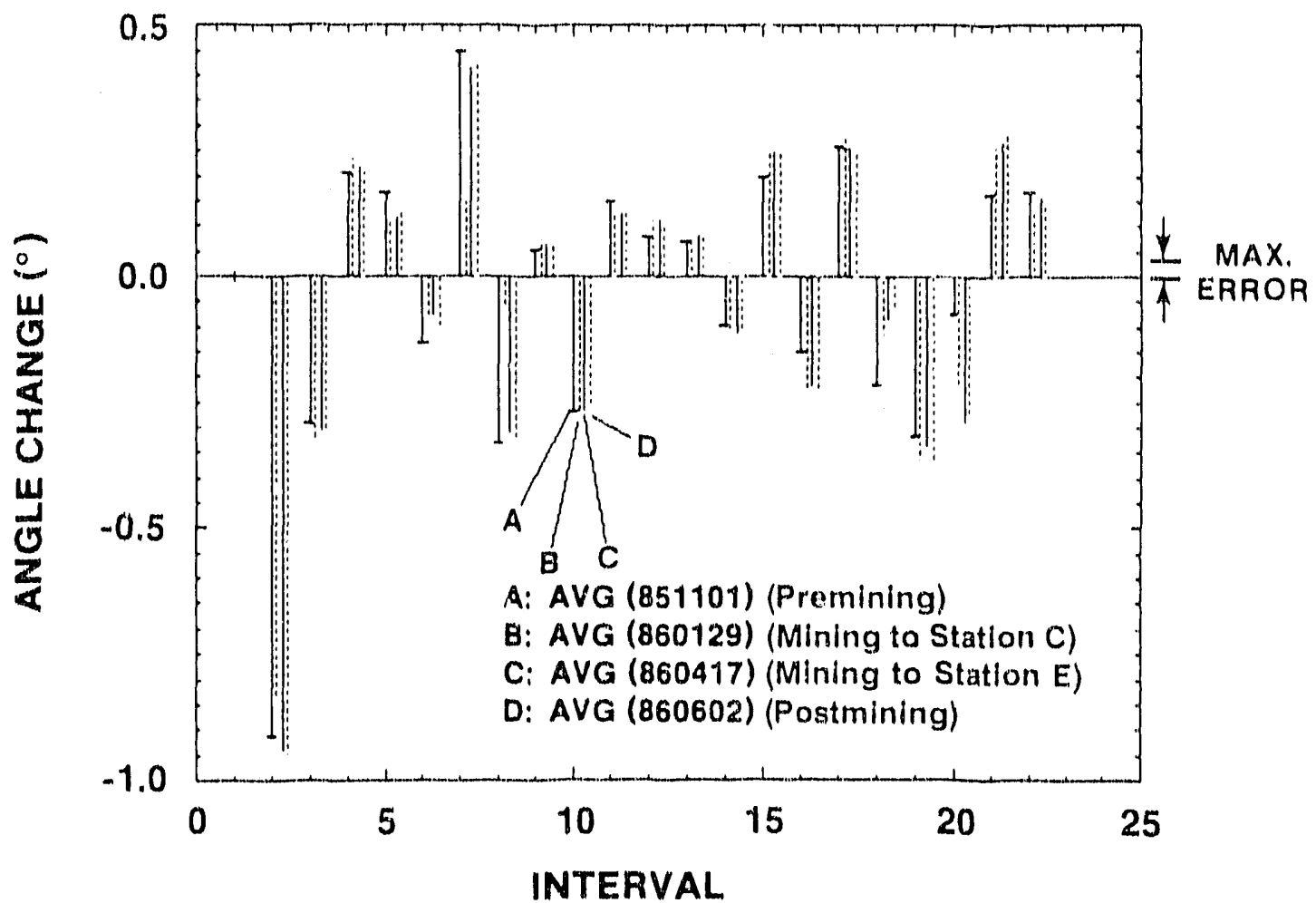

Figure 4-1.5. Angle Change Profiles for Borehole B4 


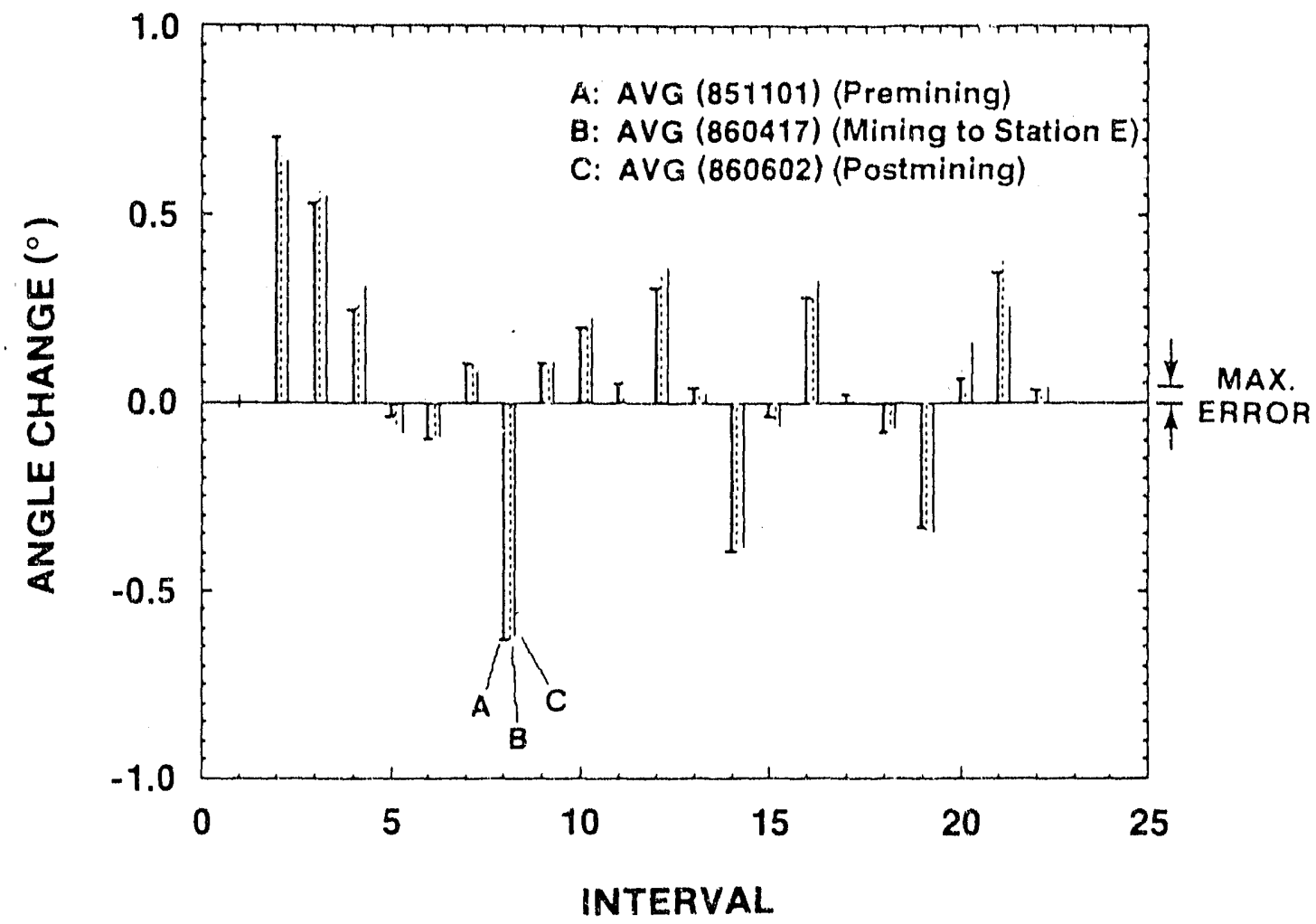

Figure 4-16. Angle Change Profiles for Borehole F1

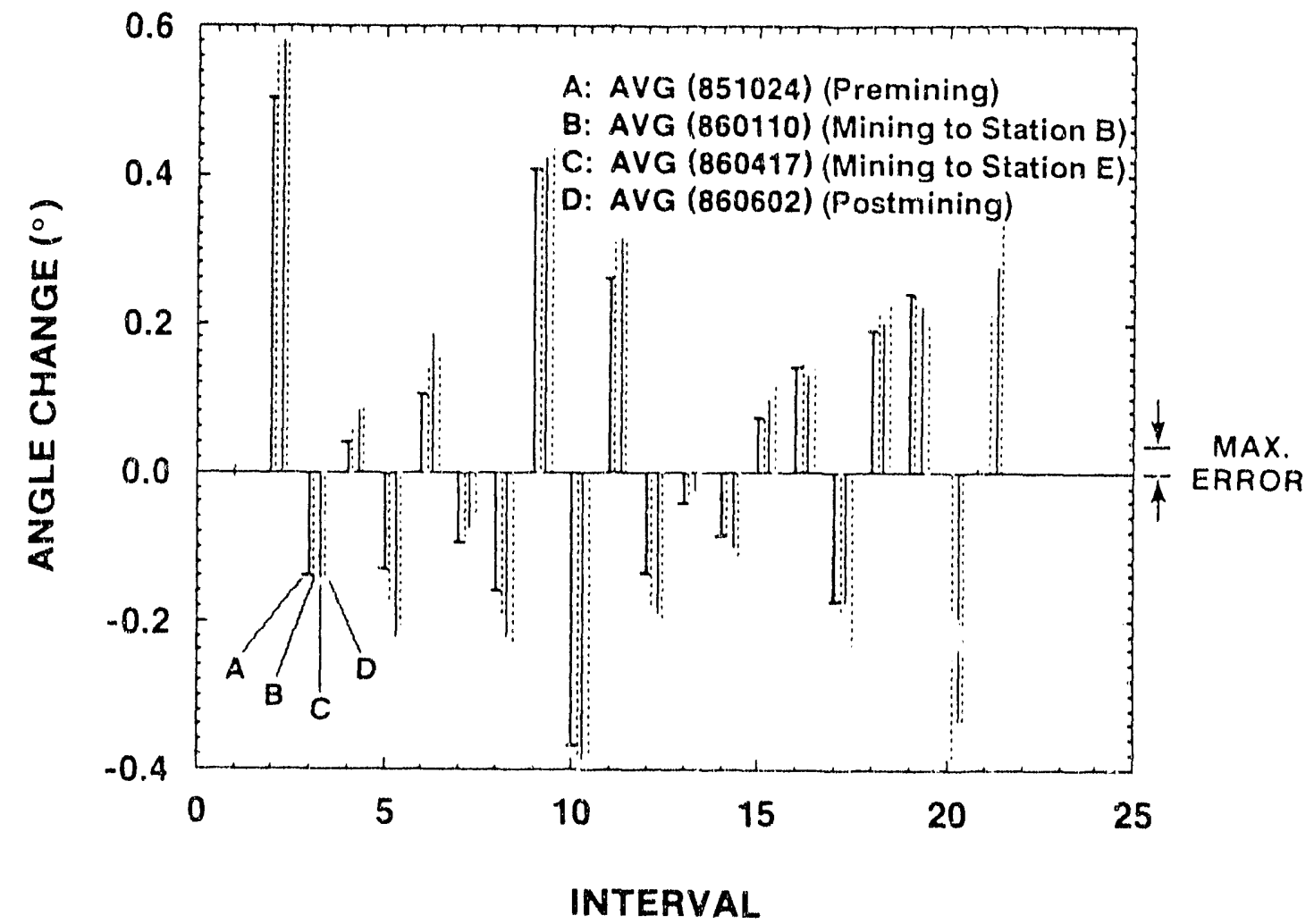

Figure 4-17. Angle Change profiles for Borenole Fi 
to determine relative changes in the rock mass due to the mining activities. The measurements between intervals $1 U$ and 16 were the closest to the excavated regions.

In general, angle changes in excess of the maximum error might have significance. Figure 4-14 shows in the 10.20 intervals that measurements in Borehole B1 indicated the most significant changes due to the mining processes. If the $B D$ could be successfully used in detecting rock mass alignment changes due to the mining, it would be expected that the differences between pre- and post-mining angle changes would have the same sign for a number of consecutive intervals and then possibly the sign of the differences would change. Figure 4-14 indicates that there are significant sign changes over only two to four intervals, a distance of 1.5 to $3 \mathrm{~m}$. Even in a fractured rock it is unlikely that the rock behaved in this manner. As an explanation, there could have been some complex stresses in the rock/grout/PVC casing interactions that contaminated the measurements. The casing might not have retained its original shape as a result of the rock mass movements. It is also possible that the measurement error of $0.034^{\circ}$ was underestimated.

\subsubsection{Evaluation}

Error analyses in Report $B$ and discussions here have shown that the $B D$ can be used to measure time-dependent changes in a hard rock mass, but that data interpretation is difficult and measurement errors are large. From an instrumentation standpoint, one problem was signal drift that appeared to be time dependent. The signal difft appeared to be predominantly a zero shift. Another major problem was the poor repeatability of measurements between ascending and descending traverses. This was a major contributor to the relatively large predicted errors (Report B). The measurement results suggest that a $B D$ might be developed for use to measure borehole alignment changes but that (1) there should be more system checks at the beginning of each borehole traverse to better document signal drifts, (2) measurement repeatabilities must be improved, and (3) PVC

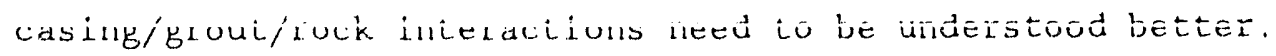


The DDM was stored underground in G-Tunnel in humidities normally over 808. Strain indicators used with the HQ measurements required occasional drying out for proper operation. Similar problems were not noticed with the DDM used with the BD measurements, but it is possible that there were undetected moisture problems.

\subsection{Hydraulic Pressure Ce11}

Hydraulic pressure cells (HPCs) were installed in wedge-shaped grout inserts to simulate underground installation conditions as a preview for planned ES testing. HPCs are used in underground applications to measure changes in stresses in concrete liners or possibly in cavities cut in rock surfaces. HPCs are planned for use in the ES liner, and the testing described here represents a familiarization effort in working with the cells. Grout was substituted for concrete to facilitate G-Tunnel operations (Report A).

\subsubsection{Measurement Principle}

Figure 4-18 is a schematic showing the major components of an HPC in place. Normally, the pressure cell with the hydraulic transducer and connecting pressure lines is cast in concrete. The cell fluid is mercury, and hydraulic oils are used in the pressure system. After the concrete has set up, the end of the repressuring tube is squeezed, thus driving the surfaces of the pressure cell firmly against the concrete surface surrounding the cell. This action integrates the HPC into the concrete structure. The repressuring line is fixed so that the mating of the cell to the surrounding material is permanent, and the action is called "lockoff." It is assumed that the cell becomes a part of the concrete structure. The pressure cell then detects any changes in the concrete stress field acting normal to the cell, and the changes in the cell pressure are assumed to be equal to the stress changes in the surrounding medium. The pressure measurement is made with the aid of a hydraulic system. Fluid is pumped into the pressure line, and it bears against the diaphragm. When the input hydraulic pressure is slightly greater than the 


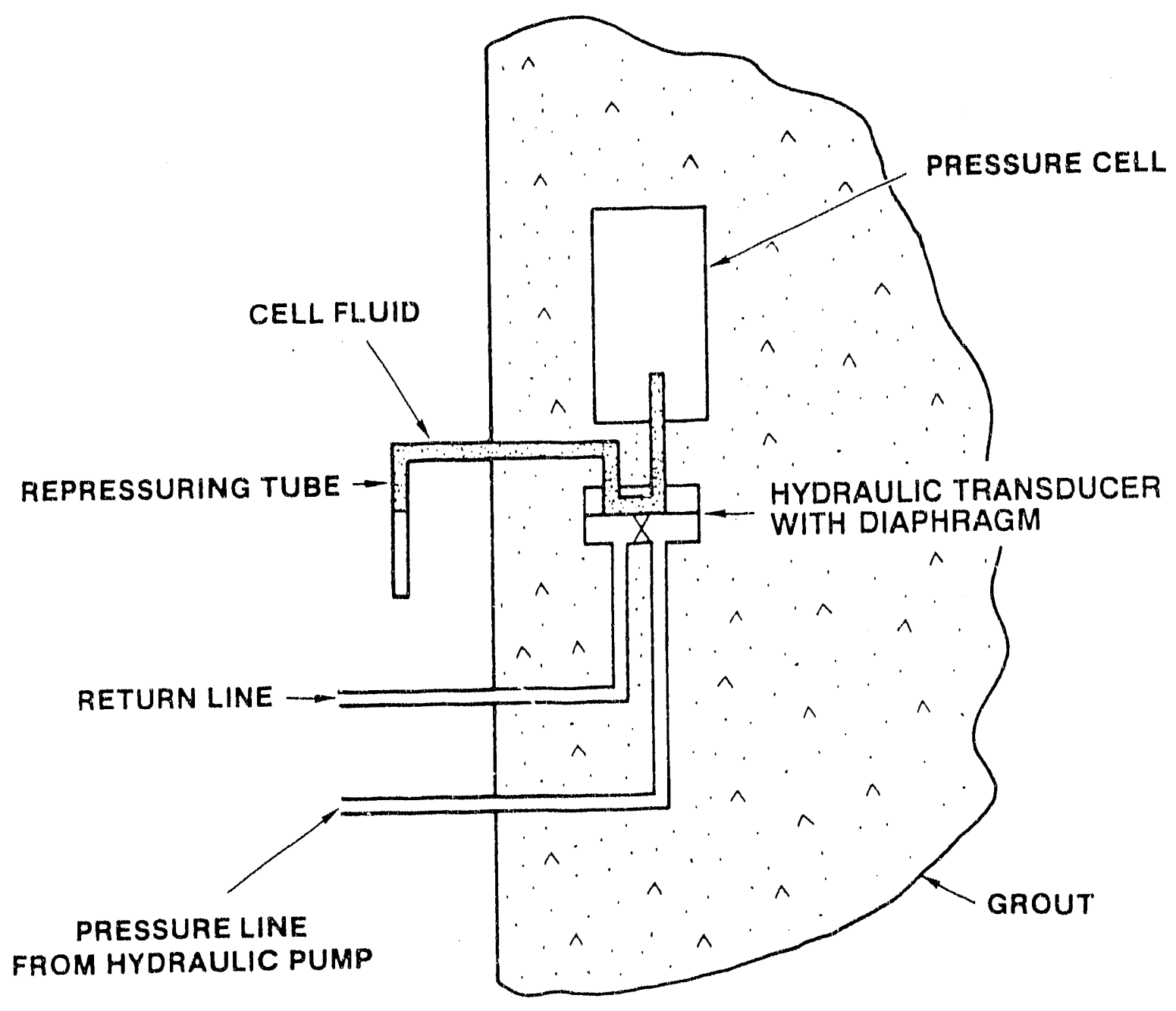

Figure 4-18. Schematic Showing Major Components of Hydraulic Pressure Cell 
cel. fluid pressure, the diaphragm in the hydraulic transducer causes a valve to open and the hydraulic fluld is pumped back to a reservolr near the hydraulic pump in the return ine.

\subsubsection{Measurement: Equipment}

Glotzl concrete stress cells, Model B 10/20, were used in the grout inserts (Table 2-2). The pressure cell was capable of measuring pressures up to $30.4 \mathrm{MPa}(4,400 \mathrm{psi})$ with a reported accuracy of $\pm 30 \mathrm{kPa}$ (4.4 psi). Each unt was $10 \times 20 \mathrm{~cm}(4 \times 8 \mathrm{in}$.). The cells were pressurized with an M1H16 hand pump, and the pressure was read directly with a pressure gage provided with the cells. The pressure gage was callbrated by the manufacturer.

\subsubsection{Installation Features}

The main goal in the use of the HPCs was to evaluate installation procedures that might be used in the $E S$. The aithors were concerned about falling concrete disturbing the HPC placement and the possibility of air pockets forming around the HPCs during the concrete placement.

Figure 4-19 is a schematic of the testing concept. A wedge-shaped cavity was mined into cwo ribs of the Demonstration Drift. The cavity was covered with a sheet of plywood which was rock-bolted to the rock, forming an enclosed cavity (Figure 3-11). The plywood held the HPCs in configurations expected for the 0.3-m-thick ES liner. An opening was made at the top of the plywood and a stiff grout, a substitute for concrete, was punped in to fill the cavity, forming a grout insert. After the grout had hardened, the pressure cells were activated to establish the lockoff pressure, and then pressures were monitored periodically afterward.

\subsubsection{Performance Observations}

Figures 4-20 and 4.21. show the pressure changes in the HPCs after the repressurization period. The pressure changos do not have any definable physical meaning. The figures show gradual increases, a trend that is 

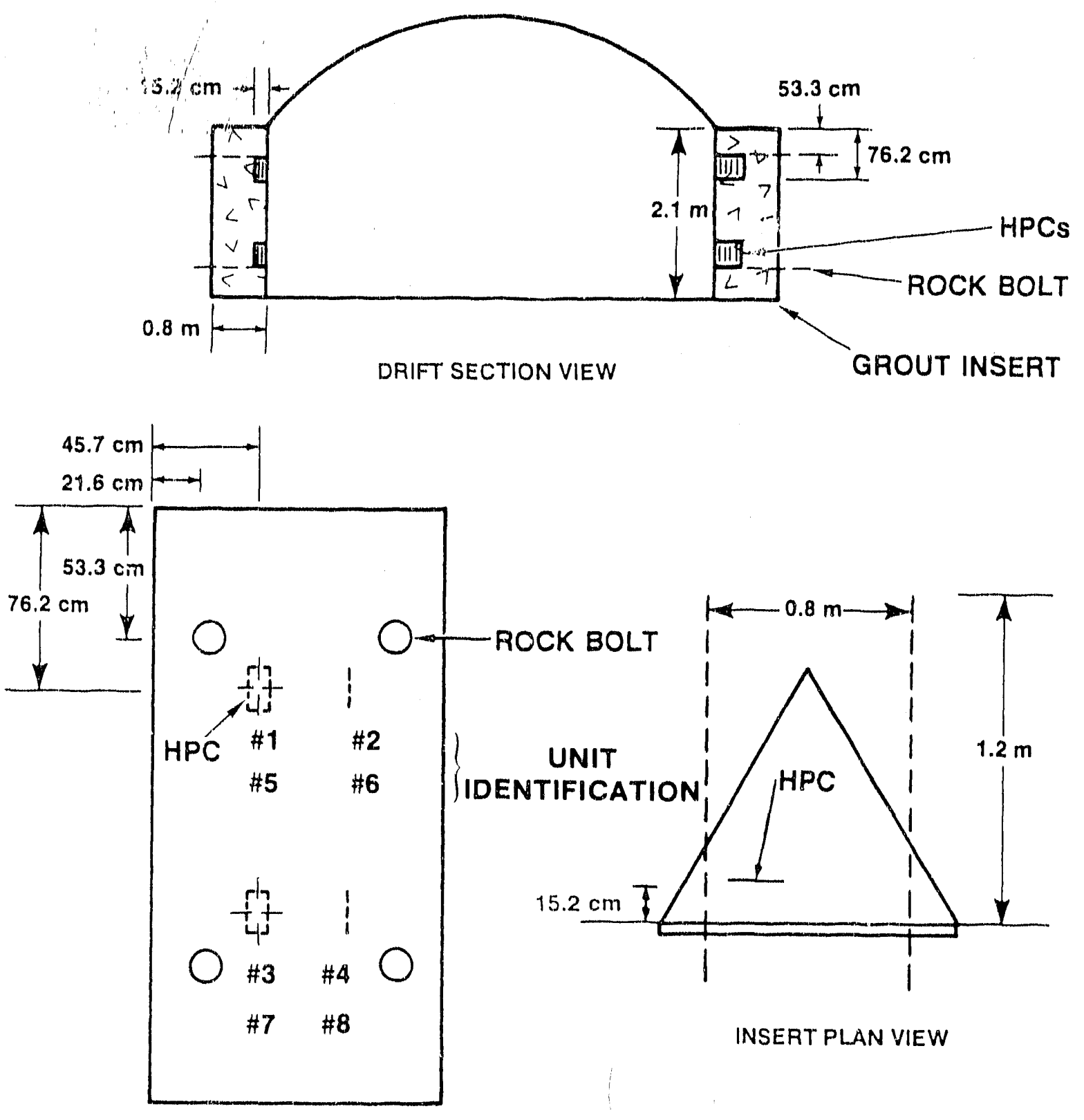

INSERT EELEVATION VIEW

Figure 4-1.9. Schematics Showing Details of the Hydraulic Pressure Cell 


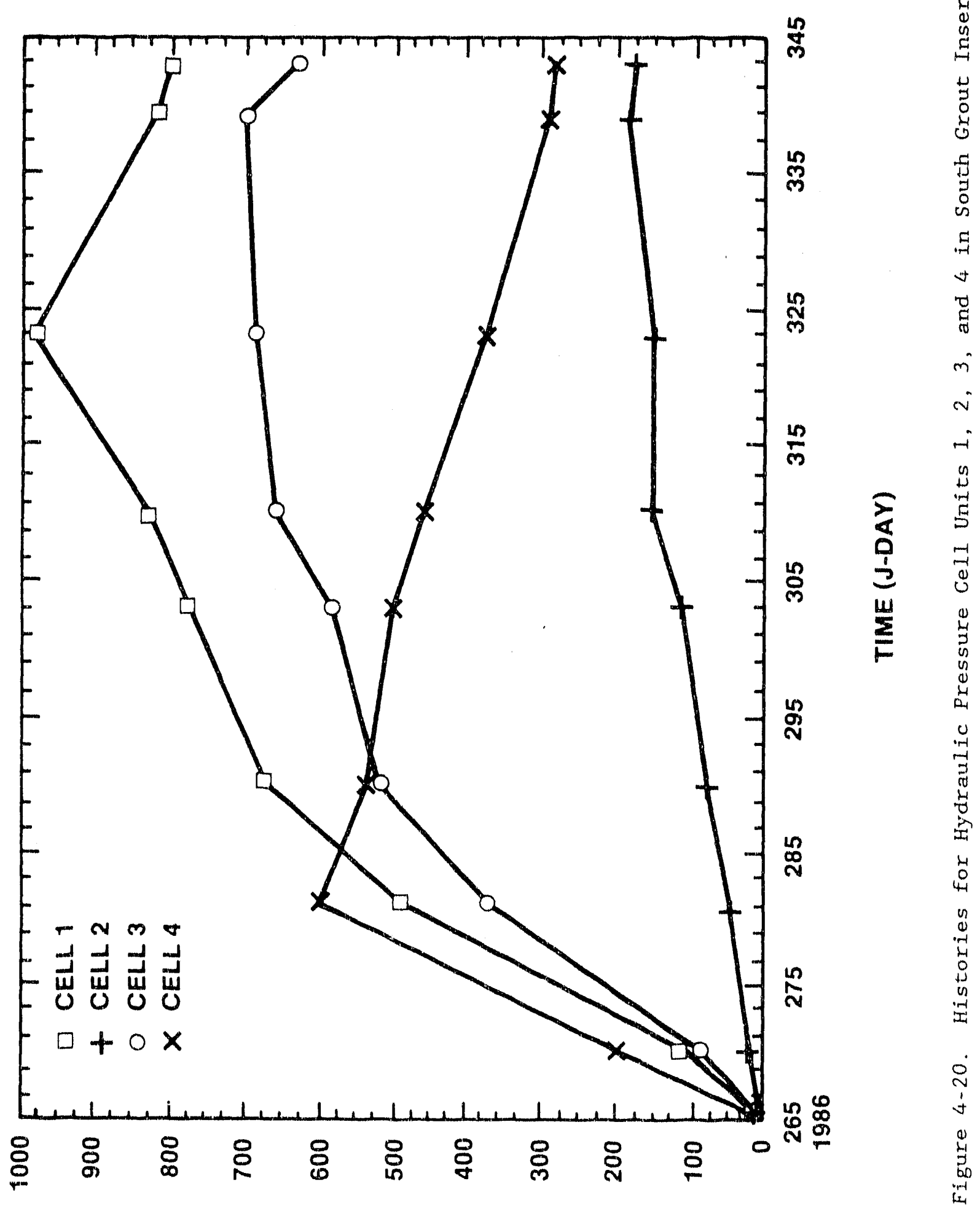

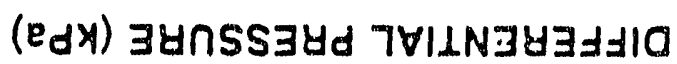




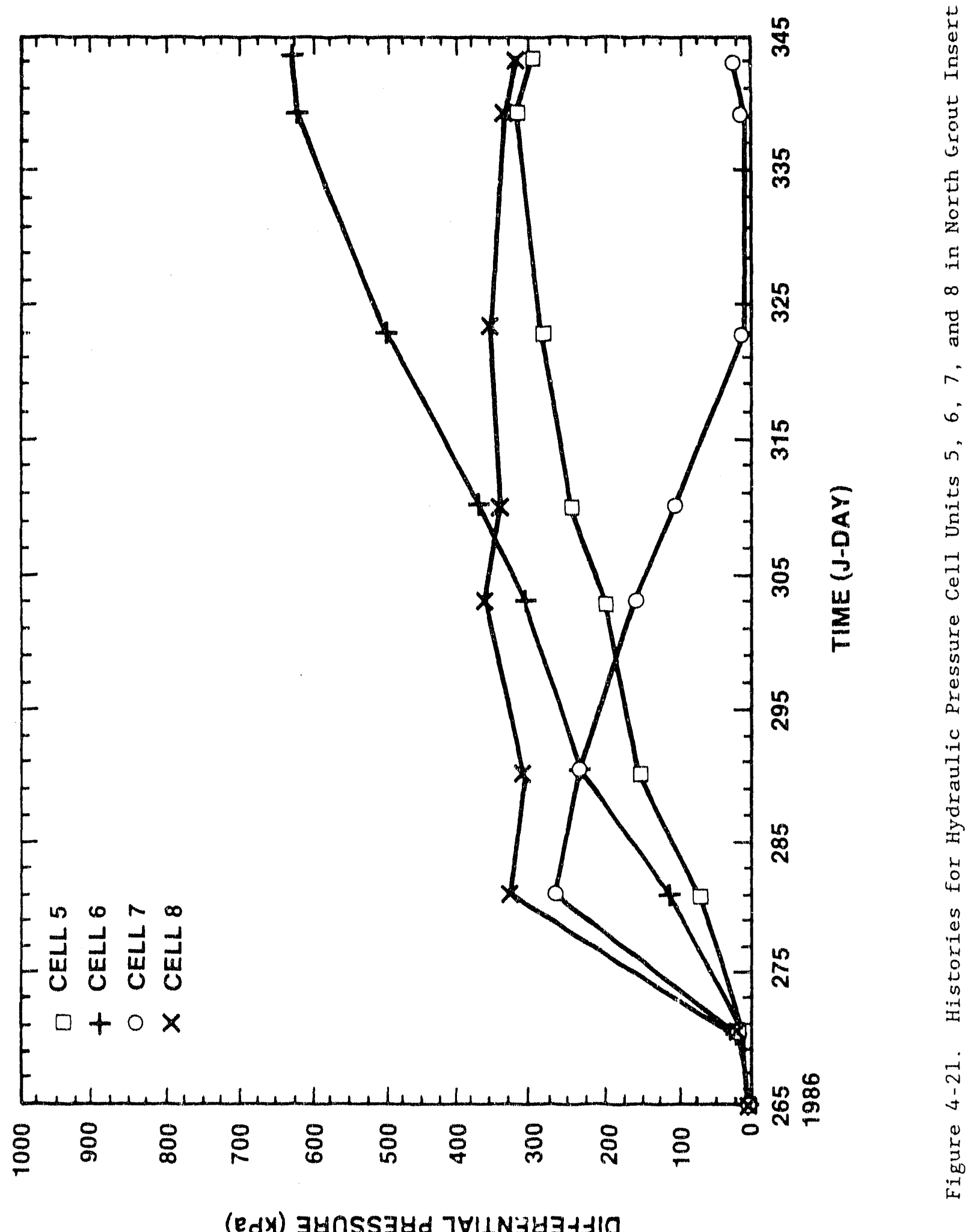

(edy) $\exists \forall \cap S S \exists \forall d 7 \forall / \perp N \exists \forall \exists \exists \unlhd 10$ 
similar to the RBLC changes (Figure 3-15). Apparentiy the grout inserts were elther plcking up load from the surrounding rock or expanding as a result of the expansive cement used in the grout (Report A).

After a pertod of 50 days (J-Day 350, 1986), the HPCs on the left $\mathrm{r}$ ib were exposed through carefully cutting away the surrounding grout to inspect for air pockets, etc. A pneumatic chipping gun was used to excavate the hardened grout from around the four cells and their hydraulic 1ines. An attempt was made to remove material from both surfaces of the cell in order to observe the quality of the grout/pressure pad interface. The cells then were photographed (Report B).

\subsubsection{Evaluation}

The HPCs were not damaged during the assembly, transportation, or installation. The surfaces were coated with a protective epoxy-based paint that minimized corrosion during use. After excavation of the cells in the left $\mathrm{rlb}$, only minor corrosion was observed on the loading surfaces and assoclated hydraulic lines. No air pockets were observed. The installation techniques appeared adequate.

Comparisons of outputs from the RBLCs and the HPCs show that there were general load increases in both cases. The irregular geometry of the grout wedge and the uncertainties of describing the structural interactions of the grout inserts and surrounding rock preclude mathematical comparisons of RBLC and HPC outputs. Thus, we can show only that the trends were similar.

One item that needs attention was noted during the pressurization of the HPCs: the tubes containing the cell fluid were not long enough for two of the eight cells. The workers had to chip away a few centimeters.of grout before the seating pressure was established. A longer tube should have been ordered. 


\subsection{SUMMARY AND RECOMMENDATIONS}

The purpose of this report is to provide descriptions and evaluations of instruments and measurement systems used in the WTM project. This report is the capstone effort for three prevtous reports dealing with preparations (Zimmerman et a1., 1991); a data sumuary (Zlmmerman et a1., 1990), and mining evaluations (Ztmerman et al., 1988). The fitrst report provides detalis of the WTM experiment and instrumentation used. The second report provides a data summary of all measurements along with calibration data and error analyses. The focus of the third report was on rock mass behavior. This report emphasizes measurement equipment and performance of instrumentation, Evaluations are provided for possible applications of these instruments in future exploratory shaft testing.

Measurement activilies for the WTM experiment were divided into two mafor groups, continuously monitored in the DAS and manually collected data. Data were collected in the underground DAS over a period of a year. Much of the instrumentation was installed in confunction with the mining process. Fourteen MPBXs, from three different manufacturers, were used to monitor displacement changes around the surface of the Demonstration Drift. Two BSMs were used to monitor pre- and postmining force changes, in the welded tuff. This was a development investigation. Sixteen RBLCs were attached to rock bolts on the drift surface and on grout inserts to detect: internal changes in the rock around the rock bolts.

A single tape extensometer was used for al1 manual cross-drift convergence measurements that were taken, generally on a weekly basis, for up to a year. In a new development, 440 HQ determinations were made from borehole pressure and flow rate measurements over a similar period of time to assess rock-mass response and relaxation resulting from the excavation process. Actually, five sets of measurements were taken for each $H Q$ determination to improve statistical significance. Fifteen BD traverses were made in another new development to investigate effects of mining on borehole alignments. Finally, eight HPCs were installed to evaluate installation and typical measurement features. Instrunentation-related evaluations are summarized by the two major groupings. 


\subsection{DAS-Monltored Instruments}

\subsubsection{Multiple-polnt Borehole Extensometers}

Three different types of MPBX.s were used in the WTM experiment. Twelve of the fourtean units were installed in recesses limmediately next to unmined faces and subjected to the high ground shock of the mining blasts. MPBXs next to unmined faces were recessed into the rock and protected from blast debris with metal plates (Report $A^{*}$ ). Two unlts were installed in the nearby 12-Drift. All MPBXs had grouted anchors and electronfc based sensors and all survived the blasting activities without apparent problems. Al1 MPBXs had adequate sensitivities to respond to the magnitudes of measurements taken. Special borehole grouting techniques had to be developed for this testing. Detalls are described 1 in Report A. From an overal1 instrunentation standpolnt, shock protection and borehole grouting procedures were manageable and appeared to be successful.

\subsubsection{IRAD Multiple-Point Borehole Extensometer}

Sonic probe IRAD MPBXs were selected for use because of two design features: (1) high resistance to electrical interference and (2) the abflity to interchange electronic and manual sensing units. The electronic units survived the blast shocks and there was no need for the manual units.

The sonic-probe MPBX had to be modifted in two ways for the experiment. First, the units had to be transformed from manually read to computer-interfaced. This was accomplished with an SNL-designed signal conversion unit. The signal conversion unit had minor problems in the form of noise and completeness in data transformation. These problems could be improved with a different design. Second, the units were shortened by the manufacturer to measure rock movements near the surface. The shortening process, in combination with the location of a nearby anchor, was not.

"Zimmerman et a1., 1991 
entirely satisfactory. Once Installed, the unlts performed well, and data were lost from only one of 12 measurement channels; this loss was attrib. uted to a slgnal conversion problem.

\subsubsection{Sinco/Terrametrics Mu1t1ple-Point Borehole Extensometer}

DC-LVDT-based MPBXs (SInco/Terrametrics) were selected for use because of (1) previous satisfactory uses in $G$ Tunne1, (2) the use of tenstoned anchor rods, and (3) the built-1n ablitty for in situ callbrations. The capability for in situ calibration allowed technicians to perform a system calibration check from sensor to DAS output. Generally, precisions achieved in laboratory calibrations (Report $B^{*}$ ) were not achievable in the fleld checks because of difficulties in measuring head displacements accurately. The main advantage was that overall measurement system confidence was enhanced because of the complete system check.

The DC-LVDT MPBX featured high measurement sensitivities. The units proved to be especially sensitive to power supply variations that were not regulated properly in the DAS. Only 1 out of 36 sensors became faulty during operation, and this could be traced to the collection of molsture in the MPBX head. The tensioned rods appeared to work properly, and data indicated that the borehole grouting process was adequate.

\subsubsection{Geokon Multiple-Polnt Borehole Extensometer}

Linear-potentiometer-based MPBXs (Geokon) were selected because of (1) simplicity of electronics and (2) potential for use with short collar pipes. A short collar pipe is significant in trying to measure convergence near the surface,

The Ifnear-potentiometer MPBX was the least sophisticated of the three. The unfis were installed easily. Three of the 12 sensors showed intermittent electrical problems. One occurred aarly in the testing, and no data were recorded. The other two performed adequately for a good

*Zimmerman et a1., 1990 
portion of the montoring perlod. An exposed wire was found on one of these two, and it is thought that molsture affected that sensor.

\section{$5,1.2$ Borehole Stiessmeters}

BSMs were selected for developmental evaluation because of their ablilty to be wedged in boreholes with the potential of surviving high ground shocks associated with blasting. BSMs are difflcult to oalibrate to obtain reliable stresses. Several callbration methods were tried (Thompson et al, 1986) and none proved to be satisfactory. The measurements Indicated that the two sensors had the same sensitivities, but attempts to relate the sensor sensitivity to rock stress predictions resulted in a discrepancy of nearly 80 percent between two unts. The measurement results should be considered qualitative at best. Clearly, BSM calibration development work is needed if BSMs are to be used in welded tuffs. Suggested areas to investigate are (1) nonlinear behavior partiliy attributed to "bedding in" of the platen into the rock and (2) calibration block material compositions and size effects.

Two BSMs were installed in the WTM effort; unfortunately, they were installed in the fault zone. One of the BSMs showed nearby blast influences in a qualitative sense, while the other did not. The Insensitive BSM was difficult to install and posslbly was not in good contact with the rock. Both BSMs showed decreases of force (implied stress) fnr a period of 100-200 days after installation. Laboratory measurements indicated that the BSMs were stable if placed in a relatively dry steel pipe, but that there were time-dependent signal losses when placed in a steel pipe under 100 r relative humidity. In general, the behavior of the BSMs suggested a need for additional development to reduce molsture sensitivities.

\section{1 .3 Rock Bolt Load Cells}

Elght RBLCs were installed on rock bolts on the roof of the Demonstration Drift and eight were on grout inserts. They were installed In an attempt to detect changes in the rock mass around the surface of the Demonstration Drift as a result of the mining activities. All were 
Installed with speclal seats to minimize alignment lnaccuracles. The rock bolts on the roof were fully grouted for safety consldarations and were not expected to plck up much load. Two out of alght showed qualitative type blasting Influences, suggesting that some rock loosenlng occurred. The RBLCs that were placed on the grout inserts showed load increases with the comparable to the HPCs. None of the RBLCis displayed instrumentation problems and they functioned as expected.

\subsection{Manually Read Measurements}

\subsubsection{Tape Extensometer}

The TE was used to obtain vertical and horizontal cross-drift measurements. The TE has a reported accuracy of $0.13 \mathrm{~mm}$; this proved satjsfactory for the measurements, which were as large as $19 \mathrm{~mm}$ (Report C). From a measurement standpoint, the TE proved to be a very rellable measuring instrument.

\subsubsection{Hydraulic Quotient:}

In a development effort, a quantity called the hydraulic quotient (HQ) was established to define changes in the rock mass using BIs. Measurements required to calculate the $H Q$ quantity were pressure, flow rate, and time. Total flow measurements were taken at each interval for quality control. BI equipment was fabricated; the instrumentation was commercially avaliable. The measurement systems proved to be reliable, with the exception that the strain indicator for the pressure measurements would sometimes become too molst and would have to be dried out. Pre- and postmining measurements showed that the accuracies of the measurements were significant to the extent that rock-mass responses were not masked by measurement uncertainties (Report $B$ ).

For the actual. HQ determinations, there were measuremerit procedures that could be improved to reduce the number of measurements taken. Better training for the operator could reduce data quality uncertainties. 


\subsubsection{Borehole Deflectometer}

In another development effort, a BD was used in an attempt to measure changes in alignments of boreholes as a function of the mining process. The BD measurements displayed time-dependent drift, which could have been influenced by storage of the $B D$ and digital readout equipment in the moist underground environment. The data displayed relatively poor repeatability for ascending and descending measurements. Repeatability was the main factor that influenced the maximum expected error. Time-dependent signal drift influenced the measurements and the concept of reviewing angle changes for measurements during a traverse was developed (Report B). Angle changes were plotted as a function of position in the boreholes. Results indicated that either complex rock/PVC casing interactions or larger than estimated measurement errors were significant and no useful data were found.

If $a \mathrm{BD}$ is to be used in future hard-rock investigations, then development work is needed. Emphasis should be on reducing measurement errors. Scoping calculations can be generated to show that the angle change for a circular arc having a $10-\mathrm{m}$-1ong chord and a radius of $2500 \mathrm{~m}$ would be less than $0.002^{\circ}$ for a $0.76-\mathrm{m}$ interval. This arc corresponds to an arc with a 5 -mm maximum deviation from the chord. Clearly measurement erxors would have to be reduced corisiderably if measurement of changes of this magnitude is to be attempted.

\subsubsection{Hydraulic Pressure Cells}

HPCs were installed in wedge-shaped grout inserts to simulate underground placement conditions. No installation problems were encountered. The units appeared to work well; the only problem was in the initial pressurization process, where workers had to chip away a few centimeters of the grout before the seating pressure was established. 


\subsection{Recormmendations}

Sections 5.1 and 5.2 provide a summary of the measurement equipment performance and evaluations. Recommendations are made in light of the findings in this report and growth in our thinking as a result of the overal1 WTM evaluations.

RECOMMENDATION 1 - MPBXs (al1 three types), RBLCs, the TE, HQ equipment, and HPCs should be favorably considered for future ES testing involving blasting.

From a measurement standpoint this equipment performed as intended and provided data. Data interpretations were easiest with the MPBXs and the TE. RBLCs were not configured for maximum response for safety reasons, but they performed well and survived the blast environment. As a posttest recommendation, strain gages with proper moisture protection should have been added to the rock bolts in lieu of the RBLCs when fully grouted rock bolts are needed. The HQ equipment could be improved as discussed in the report and appears to present a feasible way to detect rock-mass relaxation phenomena. Finally, HPCs were used to evaluate installation procedures and this process appeared to be adequate.

RECOMMENDATION 2 - BSM and BD measurement techniques should be investigated and studied for potential applications considering the problems encountered in this effort.

The BSM showed a sensitivity to the blasting in a qualitative sense. Calibration of the BSM has been known to be difficult and procedures must be improved if quantitative data are to be obtained in tuffs. The BD as configured in this effort appeared to be too insensitive for use in detecting changes in alignments. Considerable improvements in measurement techniques and possibly equipment refinements are needed before the BD can be used as intended in this study. 
RECOMMENDATION 3 - ES test procedures should include system checks for the DAS to ensure that malfunctions such as battery discharges or autostart diesel fallures are prevented.

DAS problems were discussed with the individual sensors. The main problem was in maintaining a stable voltage system in the underground environment. Underground work is complicated by a harsh environment and frequent absences of operating personne1. System quality checks are needed on a frequent basis so that operating personnel can find problems early.

RECOMMENDATION 4 - Strain-gage-based instrumentation that is to be used in a humid underground environment should be designed for that use, and test procedures should be prepared to minimize high humidity effects.

There were frequent measurement problems associated with strain-gagebased sensors and sometimes related measuring equipment. It appears that strain gage techniques should be developed for underground work and equipment should be subjected to tighter specifications. 


\subsection{REFERENCES}

Cook, C. W., and E. S. Ames, "Borehole Inclusion Stressmeter Measurements In Bedded Salt," Proceedings 20th U.S. Symposium on Rock Mechanics, Austin, TX, 1979. (NNA.890906.0182)

Hawkes, I., and W. V. Bailey, "Design, Develop, Fabricate, Test, and Demon. strate Permissible Low Cost Cylindrical Stress Gages and Associated Components Capable of Measuring Change of stress as a Function of Time in Underground Coal Mines," OFR-54-75, U.S. Bureau of Mines, Washington, DC, November 1.973. (NNA.900418.0001)

Heuze, F. E., W. C. Patrick, R. V. De la Cruz, and C. F. Voss, "In Situ Geomechanics, C1imax Granite, Nevada Test Site," UCRL-53076, Lawrence Livermore National Laboratory, Livermore, CA, April 1981. (NNA.890906.0169)

Hodgkinson, D. P., "Analysis of Steady-State Hydraulic Tests in Fractured Rock," AERE-R 11287, United Kingdom Atomic Energy Authority, Oxfordshire, UK, 1984. (NNA.900418.0005)

Johnstone, J. K., G. R. Hadley, and D. R. Waymire, "In Situ Tuff Water Migration/Heater Experiment: Final Report," SAND81-1918, Sandia National Laboratories, Albuquerque, NM, March 1985. (HQS.880517.1655)

Thompson, T. W., R. A. Bellman, Jr, and K. L. Mann, "Calibration of Rigid Inclusion Type Borehole Stressmeter Used in WTM Project," Science Applications International Corporation Report to Sandia National Laboratories, SAIC No. 1-209-07-588-00, Las Vegas, NV, 1986. (NNA. 891106.0224)

Zimmerman, R. M., R. L. Schuch, D. S. Mason, M. L. Wilson, M. E. Hall, M. P. Board, R. P. Bellman, Jr., and M. L. Blanford, "Final Report: G-Tunnel Heated Block Experiment," SAND84-2620, Sandia. National Laboratories, Albuquerque, NM, May 1986. (HQS.880517.1724)

Zimmerman, R. M., R. A. Bellman, K. L. Mann, and D. P. Zerga, "G-Tunnel Welded Tuff Mining Experiment Preparations," SAND88-0475, Sandia National Laboratories, Albuquerque, NM, January 1991. (NNA. 901127.0256)

Zimmerman, R. M., R. A. Bellman, Jr., K. L. Mann, D. P. Zerga, and M. Fowler, "G-Tunnel Welded Tuff Experiment Data Summary," SAND88-0474, Sandia National Laboratories, Albuquerque, NM, March 1990. (NNA.900214.0309)

Zimmerman, R. M., R. A. Bellman, and K. L. Mann, "G-Tunnel Welded Tuff Mining Experiment Evaluations," SAND87-1433, Sandia National Laboratories, Albuquerque, NM, December 1988. (HQS.880517.3224) 


\section{APPENDIX A}

\section{Information from the Reference Information Base \\ Used In this Report}

This report contains no information from the Reference Information Base.

\section{Candidate Information \\ for the \\ Reference Information Base}

This report contains no candidate information for the Reference Information Base.

\section{Candidate Information \\ for the \\ Slte \& Engineering Properties Data Base}

This report contains no candidate information for the Site and Engineering Properties Data Base. 
1 J. W. Bartlett, Director (RW-1)

Office of Civilian Radioactive Waste Management

U.S. Department of Energy

1000 Independence Avenue, S.W.

Washington, DC 20585

1 F. G. Peters, Deputy Director (RW-2)

Office of Civilian Radioactive Waste Maragement

U.S. Department of Energy

1000 Independence Avenue, S.W.

Washington, DC 20585

1 T. H. Isaacs (RW-4)

Office of Strateric Planning and International Programs

office of Civilian Radioactive Waste Management

U.S. Department of Energy

1000 Independence Avenue, S.W.

Washington, DC 20585

1 J. D. Saltzman (RW-5)

Office of External Relations

Office of Civilian Radioactive Waste Management

U.S. Departilent of Energy

1000 Independence Avenue, S.W.

Washington, DC 20585

1 Samue1 Rousso (RW-10)

Office of Program and Resources Management

Office of Civilian Radioactive Waste Management

U.S. Department of Energy

1000 Independence Avenue, S.W.

Washington, DC 20585

1 J. C. Bresee (RW-10)

Office of Civilian Radioactive Waste Management

U.S. Department of Energy

1000 Independence Avenue, S.W.

Washington, DC 20585

1 C. P. Gertz (RW-20)

Office of Geologic Disposal

Office of Civilian Radioactive

Waste Management

U.S. Department of Energy

1000 Independence Avenue, S.W.

Washington, DC 20585
1 S. J. Brocoum (RW-22)

Analysis and Verification Division

Office of Civilian Radioactive

Waste Management

U.S. Department of Energy

1000 Independence Avenue, S.W.

Washington, DC 20585

$1 \mathrm{~J}$. Roberts, Acting Assoc. Dir. (RW-30)

Office of Systems and Compliance

Office of Civilian Radioactive Waste Management

U.S. Department of Energy

1000 Independence Avenue, S.W.

Washington, DC 20585

$1 \mathrm{~J}$. Roberts (RW-33)

Director, Regulatory Compliance Division

Office of Civilian Radioactive Waste Management

U.S. Department of Energy

1000 Independence Avenue, S.W.

Washington, DC 20585

1 G. J. Parker (RW-332)

Office of Civilian Radioactive Waste Management

U.S. Department of Energy

1000 Independence Avenue, S.W.

Washington, DC 20585

1 R. A. Milner $(\mathrm{RW}-40)$

Office of Storage and Transportation

Office of Civilian Radioactive Waste Management

U.S. Department of Energy

1000 Independence Av rue, s.W.

Washington, DC 2058'

1 S. Rousso, Acting Assoc. Director (RW- 50)

Office of Contract Business

Management

Office of Civilian Radioactive Waste Management

U.S. Department of Energy

1000 Independence Avenue, S.W.

Washington, DC ? 9585 
1 Trudy Wood (RW-52)

Director, M\&O Management Division

Office of Civilian Radioactive

Waste Management

U.S. Department of Energy

1000 Independence Avenue, S.W.

Washington, DC 20585

1 D. U. Deere, Chairman

Nuclear Waste Technical Review Board

1100 Wilson Blvd. \#910

Arlington, VA 22209-2297

l. Dr. Clarence R. Allen

Nuclear Waste Technical Review Board 1000 E. California Blvd.

Pasadena, CA 91106

1 Dr. John E. Cantion

Nuclear Waste Technical Review Board 1795 Bramble Dr.

East Lansing, MI 48823

1 Dr. Melvin W. Carter

Nuclear Waste Technical Review Board 4621 Ellisbury Dr., N.E.

Atlanta, GA 30332

1 Dr. Donald Langmuir

Nuclear Waste Technical Review Board

109 So. Lookout Mountain Cr.

Golden, CO 80401

1 Dr. D. Warner North

Nuclear Waste Technical Review Board Decision Focus, Inc.

4984 E1 Camino Real

Los Altos, CA 94062

1 Dr. Dennis L. Price

Nuclear Wast Technical Review Board

1011 Evergreen Way

Blacksburg, VA 24060

1. Dr. E1lis D. Verink

Nuclear Waste Technical Review Board

4401 N.W. 18th Place

Gainesville, FL 32605

5 C. P. Gertz, Project Manager

Yucca Mountain Site Characterization Project Office

U S. Department of Energy

P.O. Box 98608 - MS 523

Las Vegas, NV 89193-8508
1 C. L. West, Director

Office of External Affairs

DOE Field Office, Nevada

U.S. Department of Energy

P.O. Box 98518

Las Vegas, NV 89193-8518

12 Technical Information Officer

DOE Nevada Field Office

U.S. Department of Energy

P.O. Box 98518

Las Vegas, NV 89193-8518

1 P. K. Fitzsimmons, Technical Advisor

Office of Assistant Manager for Environmental Safety and Health DOE Field Office, Nevada

U.S. Department of Energy

P.O. Box 98518

Las Vegas, NV 89193-8518

1 D. R. Elle, Director

Environmental Protection Division

DOE Nevada Field Office

U.S. Department of Energy

P.O. Box 98518

Las Vegas, NV 89193-8518

1 Repository Licensing \& Quality Assurance

Project Directorate

Division of Waste Management

U.S. Nuclear Regulatory Commission

Washington, DC 20555

1 Senior Project Manager for Yucca Mountain

Repository Project Branch

Division of Waste Management

U.S. Nuclear Regulatory Commission

Washington, DC 20555

1 NRC Document Control Desk

Division of Waste Management

U.S. Nuclear Regulatory Commission

Washington, DC 20555

1 P. T. Prestholt

NRC Site Fopresentative

301 E. Stewart Ave., Room 203

Las Vegas, NV 89101

1 E. P. Binnall

Field Systems Group Leader

Building 50B/4235

Lawrence Berkeley Laboratory

Berkeley, CA 94720 
1 Center for Nuclear Waste

Regulatory Analyses

6220 Culebi'a Road

Drawer 28510

San Antonio, TX 78284

3 W. L. Clarke

Technical Project Officer for YMP

Attn: YMP/LRC

Lawrence Livermore National

Laboratory

P.O. Box 5514

Livermore, CA 94551

4 R. J. Herbst

Technical Project Officer for YMP

N-5, Mail. Stop J521.

Los Alamos National Laboratory

P.0. Box 1663

Los Alamos, NM 87545

1 H. N. Kalta

Exploratory Shaft Test Manager

Los Alamos National Laboratory

Mail Stop 527

101 Convention Center Dr., Sulte 820

Las Vegas, NV 89109

1 J. F. Divine

issistant Director for

Engineering Geology

U.S. Geological Survey

106 National Center

12201 Sunrise Valley $[:$

Reston, VA 22092

6. L. R. Hayes

Technical Project Officer

Yucca Mountain Project Branch--MS 425

U.S. Geological Survey

P.0. Box 25046

Denver, CO 80225

1 V. R. Schneider

Asst. Chief Hydrologist--MS 4.14

office of Program Coordination

$\&$ Technical Support

U.S. Geological Survey

12201 Sunrise Valley Drive

Reston, VA 22092
1 J. S. Stuckless

Geological Division Coordinator MS 913

Yucca Mountain Project

U.S. Geological Survey

P.O. Box 25046

Denver, CO 80225

1 D. H. Appe1, Chief

Hydrologic Investigations Program MS 421

U.S. Geological Survey

P.O. Box 25046

Denver, CO 80225

1 E. J. Helley

Branch of Western Regional Geology

MS 427

U.S. Geological Survey

345 Middlefield Road

Menlo Park, CA 94025

1 R. W. Craig, Chief

Nevada Operations office

U.S. Geological Survey

101 Convention Center Drive

Suite 860, MS 509

Las Vegas, NV 89109

1 D. Zesiger

U.S. Geological Survey

101 Convention Center Dr.

Suite 860 .. MS 509

Las Vegas, NV 89109

1 R. V. Watkins, Chief

Project Planning and Management

U.S. Geological Survey

P.0. Box 25046

421 Federal Center

Denver, CO 80225

1 A. L. Flint

U.S. Geological Survey

MS 721

P.0. Box 327

Mercury, NV 89023

1 D. A. Beck

U.S. Geological Survey

1500 E. Tropicana, Suite 201

Las Vegas, NV 89119 
1 P. A. Glancy

U.S. Geological Survey

Federal Building, Room 224

Carson City, NV 89701

1 Sherman S. C. Wu

Branch of Astrogeology

U.S. Geological Survey

$2255 \mathrm{~N}$. Gemini Dr.

Flagstaff, AZ 86001

1 J. H. Sass

Branch of Tectonophysics

U.S. Geological Survey

2255 N. Gemini Dr.

Flagstaff, AZ 86001

1 DeWayne A. Campbe11

Technical Project Officer for YMP

U.S. Bureau of Reclamation

Code D-3790

P. O. Box 25007

Denver, CO 80225

1 K. W. Causseaux

NHP Reports Chief

U.S. Geological Survey

421 Federal Center

P.0. Box 25046

Denver, CO 80225

1 W. R. Keefer

U.S. Geological Survey

913 Federal Center

P.O. Box 25046

Denver, CO 80225

1 J. H, Nelson

Technical Project Officer for YMP

Science Applications International

Corp.

101 Convention Center Dr.

Suite 407

Las Vegas, NV 891.09

2 SAIC-T\&MSS Library

Science Applications International Corp.

101 Convention Center Dr.

Suite 407

Las Vegas, NV 89109
2 L. D. Foust

Nevada Site Manager

TRW Environmental Safety Systems

101 Convention Center Drive

Suite 540, MS 423

Las Vegas, NV 89109

1. C. E. Ezra

YMP Support Project Manager

EG\&G Energy Measurements, Inc.

MS V-O2

P.O. Box 1912

Las Vegas, NV 89125

1 R. E. Jackson, Program Manager

Roy F. Weston,.. Inc.

955 L'Enfant Plaza, Southwest

Washington, DC 20024

1 Technical Information Center

Roy $F$. Weston, Inc.

955 L'Enfant Plaza, Southwest

Washington, DC 20024

1 D. Hedges, Vice President,

Quality Assurance

Roy $F$. Weston, Inc.

4425 Spring Mountain Road, Suite 300

Las Vegas, NV 89102.

1 D. L. Fraser, General Manager

Reynolds Electrical \& Engineering Co.

Mail Stop 555

P.O. Box 98521

Las Vegas, NV 89193-8521

1 R. F. Pritchett

Technical Project Officer for YMP

Reynolds Electrical \& Engineering Co. MS 408

P.O. Box 98521

Las Vegas, NV 89193-8521

1 B. W. Colston

President/General Manager

Las Vegas Branch

Raytheon Services Nevada

MS 416

P.0. Box 95487

Las Vegas, NV 89193-5487 
1 R, L. Bullock

Technical Project officer for YMP

Raytheon Services Nevada

Suite P250, MS 403

101 Convention Center Dr.

Las Vegas, NV 89109

1 R, E, Lowder

Technical Project officer for YMP

MAC Technical Services

101 Convention Center Drive

Suite 1100

Las Vegas, NV 89109

1 Paul Eslinger, Manager

PASS Program

Pacific Northwest Laboratories

P.O. Box 999

Richland, WA 99352

1 A. T. Tamura

Science and Technology Division

Office of Scientific and Technical Information

U.S. Department of Energy

P.O. Box 62

Oak Ridge, TN 37831

1 Carlos G. Bell, Jr.

Professor of Civil Englneering

Civil and Mechanical Engineering

Department

University of Nevada, Las Vegas

4505 South Maryland Parkway

Las Vegas, NV 89154

1 C. F. Costa, Director

Nuclear Radiation Assessment Division

U.S. Environmental Protection Agency

Environmental Monitoring Systems Laboratory

P.O. Box 93478

Las Vegas, NV 89193.3478

1 ONWI Library

Battelle Columbus Laboratory Office of Nuclear Waste Isolation 505 King Avenue

Columbus, $\mathrm{OH} 43201$

1 T. Hay, Executive Assistant

office of the Governor

State of Nevada

Capitol Complex

Carson City, NV 89710
3 R. R, Loux, Jr.

Executive Director.

Nuclear Waste Project office

State of Nevada

Evergreen Center, Suite 252

1802 North Carson Street

Carson City, NV 89710

1 C. H. Johnson

Technical Program Manager

Nuclear Waste Project office

State of Nevada

Evergreen Center, Suite 252

1802 North Carson Street

Carson City, NV 89710

1 John Fordham

Water Resources Center

Desert Research Institute

P.O. Box 60220

Reno, NV 89506

1 Dr. Martin Mifflin

Water Resources Center

Desert Research Institute

2505 Chandler Avenue, Sulte 1

Las Vegas, NV 89120

1 Exic Anderson

Mountain West Research-Southwest Inc.

2901 N. Central Ave, $\# 1000$

Phoenix, AZ 85012-2730

1 Department of Comprehensive Planning Clark County

225 Bridger Avenue, 7 th Floor

Las Vegas, NV 89155

1 Planning Department

Nye County

P.O. Box 153

Tonopah, NV 89049

1 Lincoln County Commission

Lincoln County

P.O. Box 90

Pioche, NV 89043

5 Judy Foremaster

City of Caliente

P.O. Box 158

Caliente, NV 89008 
1 Economic Development Department City of Las Vegas

400 East Stewart Avenue

Las Vegas, NV 89101

1 Community Planning \& Development City of North Las Vegas P.O. Box 4086

North Las Vegas, NV 89030

1 Director of Community Planning City of Boulder City

P.O. Box 367

Boulder City, NV 89005

1 Commission of the European Communities 200 Rue de la Lo1

B-1049 Brussels

BELGIUM

2 M. J. Dorsey, Librarian YMP Research and Study Center Reynolds Electrical \& Engineering Co., Inc.

MS 407

P.O. Box 98521

Las Vegas, NV 89193-8521.

1 Amy Anderson

Argonne National Laboratory

Building 362

9700 So. Cass Ave.

Argonne, IL 60439

1 Steve Bradhurst

P.O. Box 1510

Reno, NV 89505

1. Phillip Niedzeilski-Eichner

13013 Lee Jackson Highway

Fairfax, VA 22033

1 Vernon Poe

P.O. Box 1026

Hawthorne, NV 89415

1 Jason Pitts

Lincoln County Courthouse

Pioche, NV 89043

1 Michael L. Baughman

35 Ciark Road

Fiskdale, MA 01518
1 Glenn Van Roeke1

Director of Community Development P.O. Box 158

Caliente, NV 89002

1 Ray Willians, Jr.

P.O. Box 10

Austin, NV 89310

1 Leonard J. Fiorenzi

P.O. Box 257

Eureka, NV 89316

1 Brad Mettau

P.O. Box 539

Goldfield, NV 89013

1 Bjorn Selinder

190 W. First St.

Fallon, N! 89406

1 Charles Thistlethwaite, AICP

Associate Planner

Planning Department

Drawer L

Independence, CA 93526

$\begin{array}{llll}1 & 6300 & \text { D. E. Miller } \\ 1 & 6302 & \text { T. E. Blejwas } \\ 1 & 6312 & \text { F. W. Bingham } \\ 1 & 6313 & \text { L. S. Costin } \\ 1 . & 6316 & \text { R. P. Sandoval } \\ 2 & 6318 & \text { R. J. Macer for } \\ & & \text { 100/124213/SAND88-1331/NQ } \\ 1 & 6319 & \text { R. R. Richards } \\ 1 & 2741 & \text { R. M. Zimmerman } \\ 5 & 3141 & \text { S. A. Landenberger } \\ 8 & 3145 & \text { Document Processing } \\ 3 & 3151 & \text { G. Cor DoE/OSTI } \\ 2.0 & 6341 . & \text { WMT Library } \\ 1 & 6410 & \text { D. A. Dahlgren } \\ 1 & 8523-2 & \text { Central Technical Files }\end{array}$

16300 D. E. Miller

16302 T. E. Blejwas

16312 F. W. Bingham

16313 L. S. Costin

1. 6316 R. P. Sandoval

26318 R. J. Macer for

16319 R. R, Richards

12741 R. M. Zimmerman

53141 S. A. Landenberger

83145 Document Processing

for DOE/OSTI

33151 G. C. Claycomb

206341 WMT Library

1 8523-2 Central Technical Files 
SAND88-1331

The number in the lower right-hand corner is an accession number used for Office of Civilian Radioactive Waste Management purposes only. It should not be used when ordering this publication. 

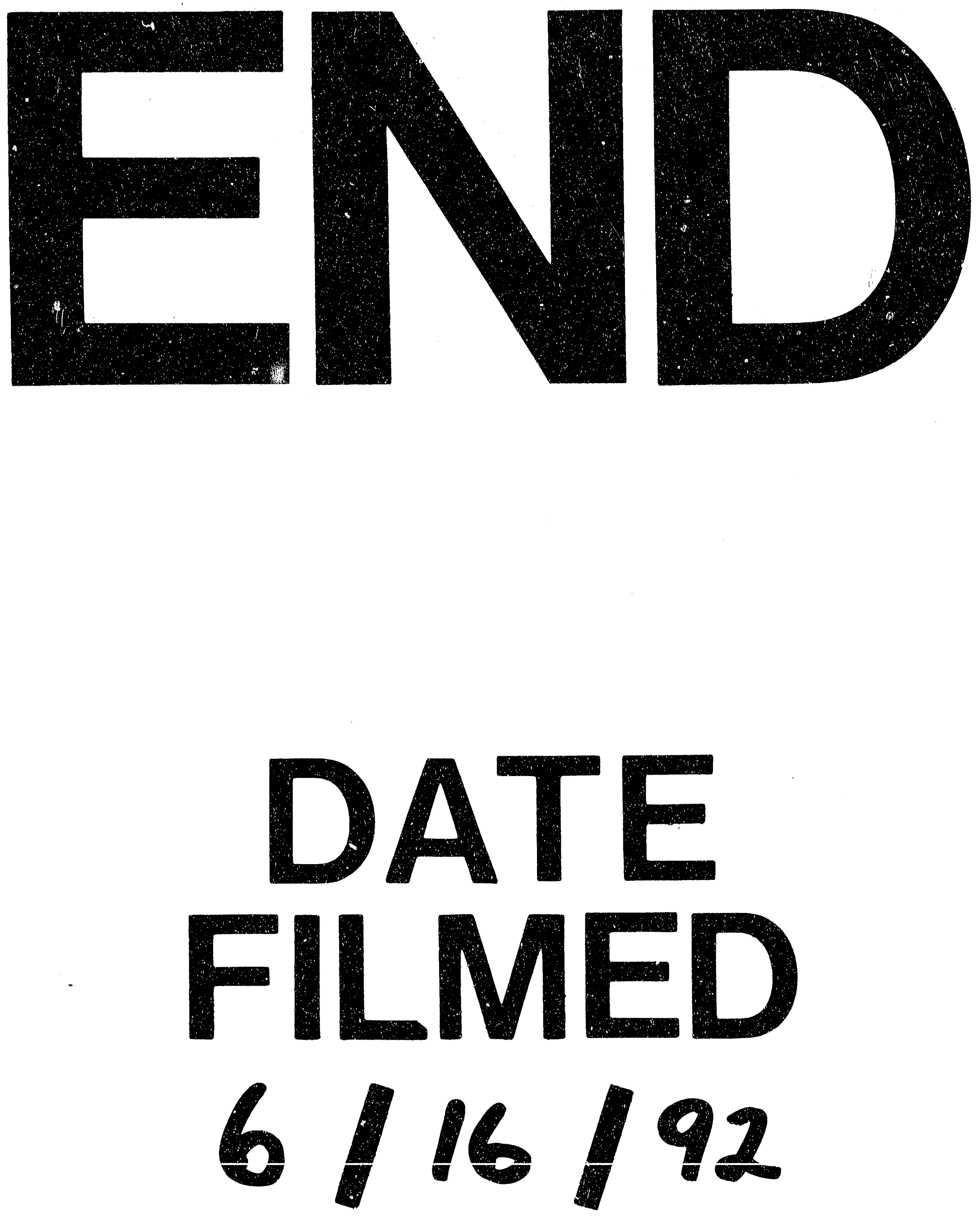
